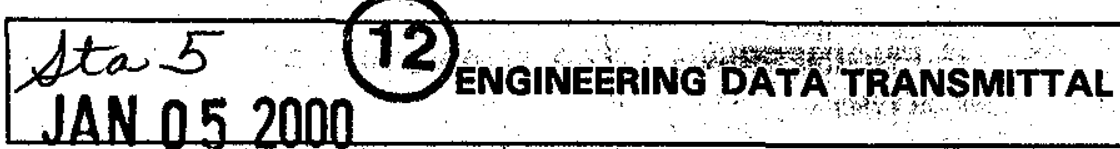

ind

\begin{tabular}{|c|c|}
\hline $\begin{array}{l}\text { 2. To: (Recelving Organization) } \\
\text { Distribution }\end{array}$ & $\begin{array}{l}\text { 3. From (Orfohating Organization) } \\
\text { FDH TOPS Analytical Chemistry }\end{array}$ \\
\hline $\begin{array}{l}\text { 5. Proj/Prog./Dept./Div.: } \\
8 D 500\end{array}$ & $\begin{array}{l}\text { 6. Design Authority/Design Agent/Cog. Engr. } \\
\text { B. A. Crawford }\end{array}$ \\
\hline
\end{tabular}

8. Originator Remarks:

Test plan describes calibration tests and simulant analyses of

Retained Gas sampler for ammonia analysis.

Page 1 of

1. EDT 626587

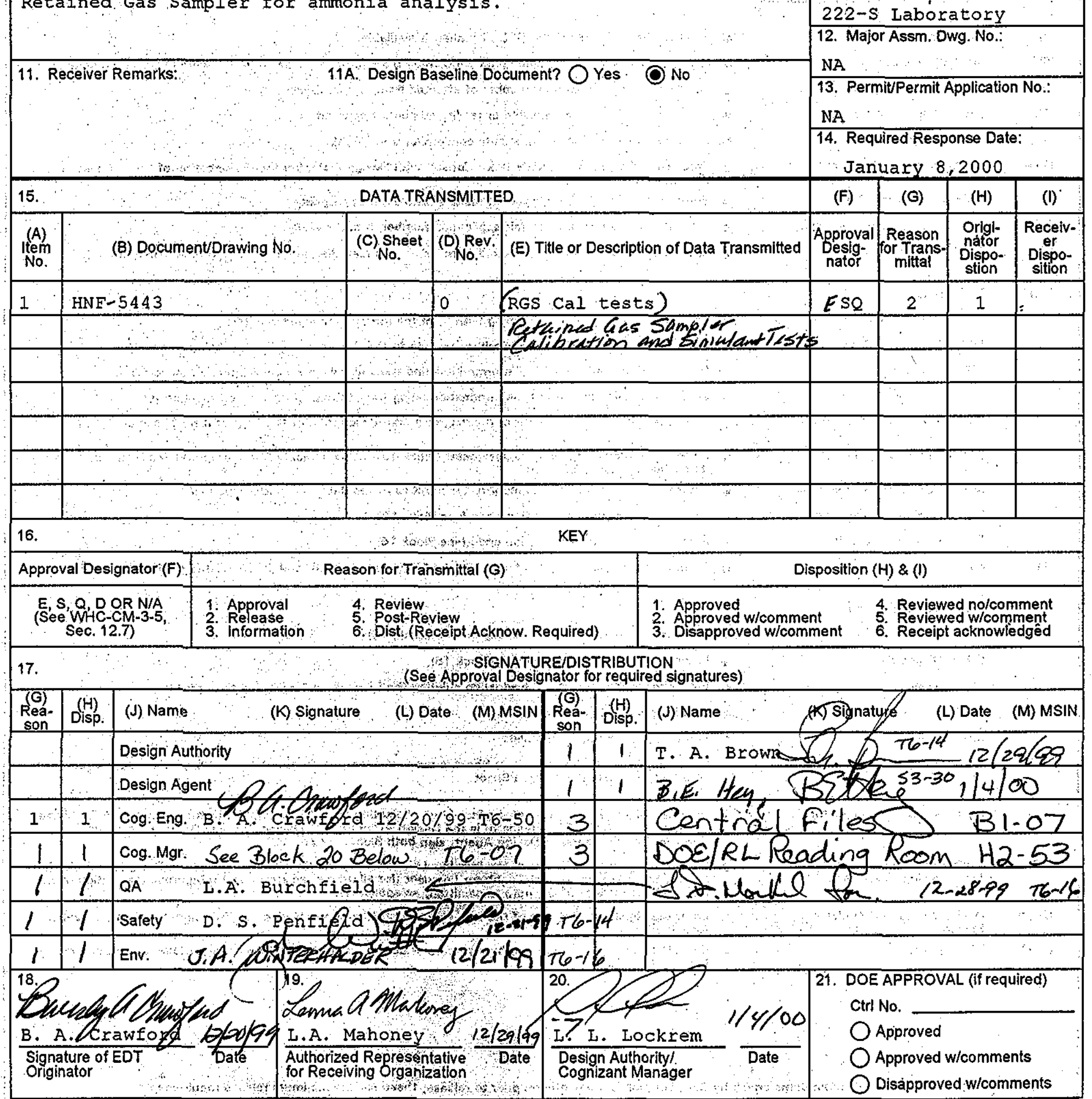




\title{
Retained Gas Sampler Calibration and Simulant Tests
}

\author{
B. A. Crawford \\ Fiuor Daniel Hanford Corporation \\ Richland, WA 99352 \\ U.S. Department of Energy Contract DE-AC06-96RL13200 \\ $\begin{array}{llll}\text { EDT/ECN: } 626587 & \text { UC: } 2000 & \text { (COA) } \\ \text { Org Code: } & 8 D 500 & \text { Charge Code: } 101897 & \text { BA10 } \\ \text { B\&R Code: } & E W 3 / 30000 & \text { Total Pages: } 109 & \end{array}$
}

Key Words: retained gas sampler, RGS, ammonia, ammonium hydroxide, isotopic ratios, pressure, temperature, extractor, calibration, simulant solids, simulant solution

Abstract: This test plan provides a method for calibration of the retained gas sampler (RGS) for ammonia gas analysis. Simulant solutions of ammonium hydroxide at known concentrations will be diluted with isotopically labeled $0.04 \mathrm{M}$ ammonium hydroxide solution. Sea sand solids will also be mixed with ammonium hydroxide solution and diluent to determine the accuracy of the system for ammonia gas analysis.

Sharpie is a registered trademark of Sanford Ink Co., Bellwood, IL

Imbiber Beads is a registered trademark of Imbibitive Technologies Corp., Wilmington, DE

Clean Up is a registered trademark of Excel-Mineral Co., Inc., Goleta, CA

Eppendorf is a registered trademark of Eppendorf-Netheler-Hinz GMBH, Hamburg, Germany

TRADEMARK DISCLAIMER. Reference herein to any specific commercial product, process, or service by trade name, trademark, manufacturer, or otherwise, does not necessarily constitute or imply its endorsement, recommendation, or favoring by the United States Government or any agency thereof or its contractors or subcontractors.

Printed in the United States of America. To obtain copies of this document, contact: Document Control Services, P.O. Box 950, Mailstop H6-08, Richland WA 99352, Phone (509) 372-2420; Fax (509) 376-4989.

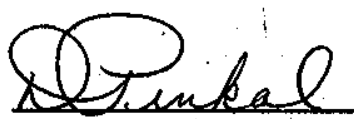

Release Approval

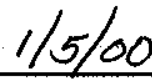

Date

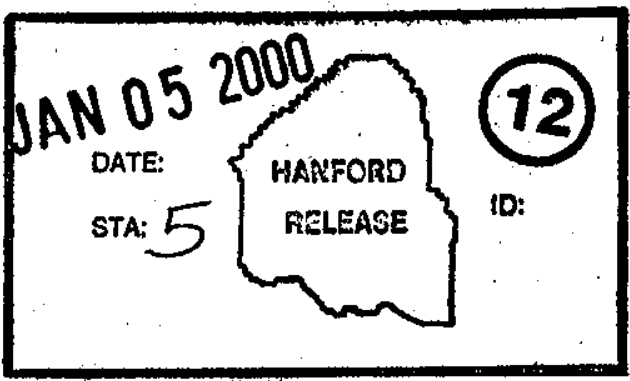

Release Stamp 
HNF-5443, rev. 0

\section{TABLE OF CONTENTS \\ RETAINED GAS SAMPLER CALIBRATION AND SMMULANT TESTS}

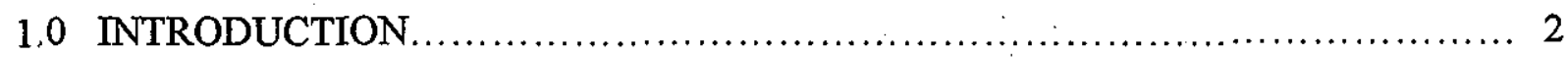

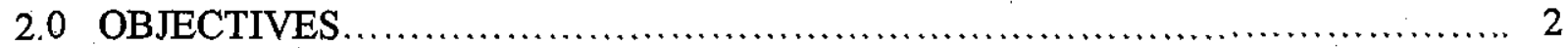

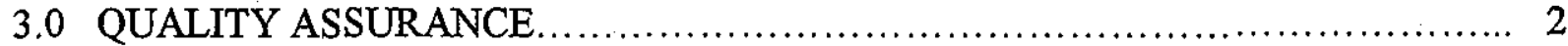

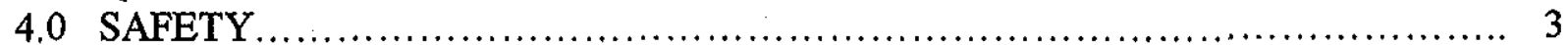

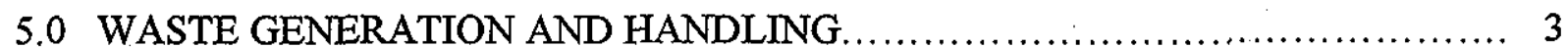

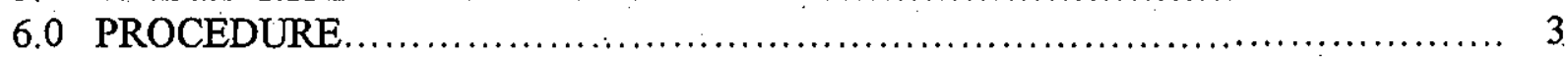

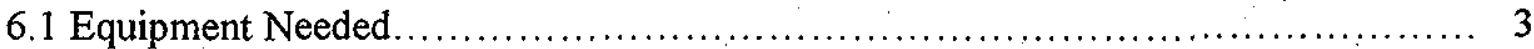

6.2 Phase I Testing ......................................................... 4

6.2.1 Solution Preparation and Analysis............................... 4

6.2.2 Introduction of Solution to Extractor and Equilibrium............... 4

6.2.3 Pump System for Sample (24 hours only) ......................... 5

6.2 .4 Collect Samples and Data........................................ 6

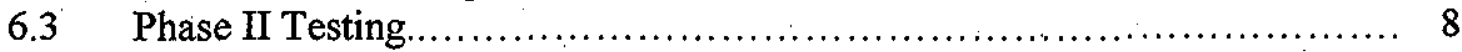

6.3.1. Solution Tests................................................ 8

6.3.1.1 Solution Preparation and Analysis....................... 8

6.3.1.2 Introduction of Solution to Extractor and Collection of

Preliminary Samples........................................ 8

6.3.1.3 Introduction of the Diluent to the Extractor................. 10

6.3.1.4 Sampling at 24-hour, 4 days and 16 days from Test Initiation. 11

6.3.2 Concentrated Solution Tests................................... 13

6.3.2.1 Solution Preparation and Analysis.......................... 13

6.3.2.2 Introduction of Solution to Extractor and Collection of

Preliminary Samples...................................... 14

6.3.2.3 Introduction of the Diluent to the Extractor................ 16

6.3.2.4 Sampling at 24-hour, 4 days and 16 days from Test Initiation 16

6.3.3 Solution/Solids Tests............................................. 19

6.3.3.1 Solution Preparation and Analysis.......................... 19

6.3.3.2 Introduction of Simulant Solid and Solution to Extractor..... 19

6.3.3.3 Introduction of the Diluent to the Extractor................. 22

6.3.3.4 Sampling at 24-hour, 4 days and 16 days from Test Initiation 22

7.0 REPORTING REQUTREMENTS ............................................... 25

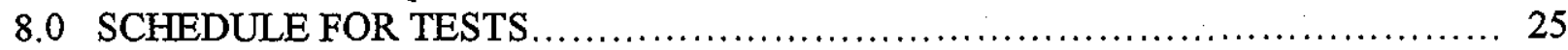

Appendices

Appendix A: LO-100-151 Segregate and Manage Solid Laboratory Wastes.................. A1

Appendix B: LO-160-101 IE-2 Hot Cell Airlock Operations ................................... B1

Appendix C: LT-160-101 Retained Gas Sampler Operation ............................... C1 


\author{
HNF-5443, rev. 0
}

\title{
RETAINED GAS SAMPLER CALIBRATION AND SIMULANT TESTS
}

\subsection{INTRODUCTION}

This test plan describes a method for testing and calibrating ammonia measurements made by the system used for extraction and separation of retained gas from waste tank core samples. Under normal operation, the waste tank core segment sample is delivered to the laboratory in a special gas tight waste tank core sampler that contains the gas phase component of waste tank sample material along with the bulk material. Normally the sampler is loaded into the $1 \mathrm{E}-2$ hot cell according to procedure LO-160-101, Core Segment Load-in and Load-out of 1E-2 Hot Cell. The sampler is then coupled to the extractor of the Retained Gas Sampler (RGS) system in a way that ensures vacuum integrity. The extractor is evacuated. Vapors contained inside the core sampler are extruded into the extractor with the bulk sample material then are pumped, using a liquid mercury positive displacement pump, to collection canisters located outside the hot cell. A high-efficiency in-line depth filter prevents the transfer of radioactive particles to the collection canisters. The collection canisters can then be removed from the system for analysis of the gases.

As part of this test plan the RGS system will be calibrated using a $0.04 \mathrm{M}$ concentration of isotopically labeled ${ }^{15} \mathrm{NH}_{4} \mathrm{OH}$ solution.

\subsection{OBJECTIVES}

This test plan describes the calibration and sampling requirements for use of the retained gas sampler (RGS) equipment for ammonia gas extraction from solid and liquid samples in the 1E-2 hot cell in the 222-S facility. Pre-analyzed solutions of ammonium hydroxide will be run through vapor extraction tests to determine the accuracy of ammonia measurements made for a water matrix in the retained gas-sampling unit. Tests will then be expanded to include analysis of $\mathrm{NH}_{3}$ in a more concentrated ammonium hydroxide solution or one of identical concentration as the previous tests containing approximately 40 volume $\%$ solids.

\subsection{QUALITY ASSURANCE}

Data obtained during these tests include temperature and pressure readings. Log sheets on which data are recorded are pasted into a controlled laboratory notebook. These sheets will be sent via facsimile to PNNL for data interpretation and use.

Temperature measurements are obtained through use of K-type thermocouples. Calibration of the temperature sensing capability of the RGS system is not routinely performed; rather several readings are acquired simultaneously from different locations of the RGS system for redundant verification. 
Four of the five pressure measurements are made using instruments that are calibrated annually, the fifth (non-calibrated) pressure measuring instrument is used for convenient indication only. Calibrations are performed on pressure transducers by the manufacturer at the factory. These are maintained on a preventative maintenance schedule.

\subsection{SAFETY}

The RGS extraction system may involve using compressed gases that are used to purge the system, periodically. Although these gases are regulated to low and easily manageable pressures, care should be exercised to ensure the system does not exceed $133 \mathrm{kPa}$ (4.6 psig). This ensures sensitive pressure and temperature sensors will not be damaged. To further ensure the instruments are protected, valves should be closed when the system is not in use.

The RGS extraction system uses liquid mercury in the displacement pump. Although the mercury is safely contained within the RGS system, care should be exercised when performing plumbing operations on the system because beads of mercury may be encountered when breaching some system lines. If a spill of metallic mercury does occur, the Shift Operations Manager (SOM) must be notified after personnel in the area are warned of the spill and the spill is isolated.

In the event that the system lines and plumbing should be breached to effect repair or replacement of instruments or fittings, an HPT must be present to conduct surveys to monitor and control the spread of radioactive contamination.

\subsection{WASTE GENERATION AND HANDLING}

During these tests some solid waste may be generated from the use of glass silica beads with solutions being tested. These wastes will be packed and loaded out of the hot cell in accordance with LO-100-151, Segregate and Manage Solid Laboratory Wastes, section 3.4, 6.9 and 6.10 (see appendix A) and LO-160-101, IE-2 Hot Cell Airlock Operations , sections 6.1 through 6.6 as necessary (see appendix B).

Contaminated rinse water, generated during preparation and post processing wash downs, is released to the hot cell drains as per LO-100-151 housekeeping procedures (see appendix A). The building operations manager should be notified prior to wash down activities or anytime water is used in the hot cell.

\subsection{PROCED́URE}

\subsection{Equipment Needed}

Gas Sample Collection Canisters (dwg. \# H-2-821611)

Controlled Laboratory Notebook (HNF-40-2)

Retained Gas Sampler System (dwg. \#H-2-821609)

Manifold System Control Cabinet and Contents (dwg. \#H-2-85291)

Turbo-molecular Vacuum Pump 
HNF-5443; rev. 0

Equipment Needed (cont.):

Rotary Vane Vacuum Pump

Temperature Controlled Water Bath (Heater/Chiller)

Assorted Tools and Mock Sampler for operation of the extruder

Sample vials, $15 \mathrm{~mL}$ with septum lids

Polybottles (1L)

\subsection{Phase I Testing}

Note - All system equilibration and system leak checks should be performed and documented prior to sample introduction according to the protocol established in LT-160-101 (appendix C) sections 10.1.2 and 10.2.2.

\subsubsection{Solution Preparation and Analysis}

1. Make up $500 \mathrm{ml} 0.04 \mathrm{M}^{15} \mathrm{NH}_{4} \mathrm{OH}$ solution.

2. Shake solution prior to dispensing.

3. Fill a $15-\mathrm{ml}$ vial with a septum lid to the top with solution.

4. Submit the $15-\mathrm{ml}$ vial for ammonia analysis by ion selective electrode (ISE).

\subsubsection{Introduction of Solution to Extractor and Equilibration}

1. Ensure canisters are attached to ports $J 1$ and $J 2$ and that the canister valves are open for evacuation.

2. Ensure the extruder is isolated from the evacuated system by closing valve $\mathrm{T}$.

3. Dispense approximately $100 \mathrm{ml}$ diluent through valve $\mathrm{W} 2$ and then ensure valve $\mathrm{W} 2$ is closed.

4. Introduce $300 \mathrm{ml}$ of the ${ }^{15} \mathrm{NH}_{4} \mathrm{OH}$ solution to the RGS mixing chamber through valves $\mathrm{W} 1$ and $\mathrm{W} 3$ using the diluent reservior.

5. Assure the system temperature is at 10 to $12^{\circ} \mathrm{C}$.

Note - The motor speed of the extractor is $60 \mathrm{rpm}$ when the controller dial on the RGS console is dialed to 999 .

6. Begin mixing solution by turning on the mixing motor and adjusting the motor speed to 60 rpm. 
HNF-5443, rev. 0

7. When system temperature and pressure stabilizes, record the date, time, event, temperature and pressure on the RGS processing worksheet and post in the controlled notebook.

Note - Temperature is maintained at $10^{\circ} \mathrm{C}$ and mixing continues for 24 hours of equilibration.

8. Allow the solution to equilibrate in the mixing chamber for 24 hours.

\subsubsection{Pump System for Sample ( 24 hours only)}

1. Set automatic data acquisition to 10 -second interval data log and record data file name in notebook.

2. Ensure the following valve configurations:

\begin{tabular}{|l|l|}
\hline Closed & $\mathrm{H} 3, \mathrm{~J} 3, \mathrm{~K} 2, \mathrm{M} 2, \mathrm{~N} 1, \mathrm{~N} 2, \mathrm{~N} 3, \mathrm{~N} 4, \mathrm{R}, \mathrm{S}, \mathrm{T}, \mathrm{U}, \mathrm{V}, \mathrm{W} 1, \mathrm{~W} 2, \mathrm{~W} 3, \mathrm{Y}, \mathrm{Z}$ \\
\hline Open & $\mathrm{A}, \mathrm{B}, \mathrm{C}, \mathrm{D}, \mathrm{E}, \mathrm{F}, \mathrm{G}$ (to collector),H1,H2,J1,J2,K1,M1 \\
\hline
\end{tabular}

3. Ensure system pressure is less than $0.01 \mathrm{kPa}$.

4. Adjust pressure indicator zero offsets as necessary.

5. Close valve $\mathrm{K} 1$.

6. Open valve $\mathrm{T}$.

7. When system temperature and pressure stabilizes, record date, time, event, temperature and pressure in the controlled notebook.

8. Close valve $\mathrm{F}$ and ensure valve $\mathrm{G}$ is turned to the collector side.

9. Perform the following steps 12 times initialing each step as performed:

\begin{tabular}{|l|l|l|l|l|l|l|l|l|l|l|l|l|}
\hline Step & 1 & 2 & 3 & 4 & 5 & 6 & 7 & 8 & 9 & 10 & 11 & 12 \\
\hline $\begin{array}{l}\text { a. Raise the mercury reservoir above } \\
\text { the 0-point. }\end{array}$ & & & & & & & & & & & & \\
\hline b. Open valve U. & & & & & & & & & & & & \\
\hline $\begin{array}{l}\text { c. Control flow of mercury with G, } \\
\text { sight glass and mercury reservoir } \\
\text { level. }\end{array}$ & & & & & & & & & & & & \\
\hline $\begin{array}{l}\text { d. Lower mercury reservoir to bottom } \\
\text { of travel. }\end{array}$ & & & & & & & & & & & & \\
\hline $\begin{array}{l}\text { e. Record the system temperature and } \\
\text { pressure in notebook. }\end{array}$ & & & & & & & & & & & & \\
\hline
\end{tabular}


HNF-5443, rev. 0

\begin{tabular}{|c|c|c|c|c|c|c|c|c|c|c|c|c|}
\hline Step & 1 & 2 & 3 & 4 & 5 & 6 & 7 & 8 & 9 & 10 & 11 & 12 \\
\hline $\begin{array}{l}\text { f. Turn valve } \mathrm{G} \text { to the extractor } \\
\text { and wait until mercury complete } \\
\text { evacuates displacement bulb. }\end{array}$ & & & & & & & & & & & & \\
\hline g. Close valve U. & & & & & & & & & & & & \\
\hline h. Turn valve $\mathrm{G}$ to collector side & & & & & & & & & & & & \\
\hline i. Repeat steps until completed. & & & & & & & & & & & & \\
\hline
\end{tabular}

10. Raise the mercury reservoir above 0 -point.

11. Open valve $U$ and control the flow of mercury to the sight glass with valve $G$ and height of the reservoir.

12. Lower the mercury reservoir to bottom of travel.

13. Record the temperature and pressure in the controlled notebook.

14. Close the valves on the gas sample canisters at port $\mathrm{J} 1$ and $\mathrm{J} 2$ and $\mathrm{H} 1$ and $\mathrm{H} 2$.

15. Record the vapor sample canister $\mathrm{ID}$, temperature and pressure in the notebook.

16. Stop data acquisition, close file, and copy file to a floppy disk.

\subsubsection{Collect Samples and Data}

1. Remove the canisters at ports $\mathrm{J} 1$ and $\mathrm{J} 2$.

2. Survey each vapor canister by swabbing in and around the connector tube and then surveying the swab for removable radioactive contamination.

3. Replace canisters $\mathrm{J} 1$ and $\mathrm{J} 2$ with valves open.

4. Ensure the valves are in the configuration shown and initial each step when complete:

\begin{tabular}{|l|l|l|}
\hline $\begin{array}{l}\text { Valve } \\
\text { ID }\end{array}$ & Status & Completed \\
\hline B & Open & \\
\hline K2 & Closed & \\
\hline M2 & Closed & \\
\hline N1 & Closed & \\
\hline N2 & Closed & \\
\hline N3 & Closed & \\
\hline N4 & Closed & \\
\hline R & Closed & \\
\hline S & Closed & \\
\hline U & Closed & \\
\hline
\end{tabular}


HNF-5443, rev. 0

\begin{tabular}{|l|l|l|}
\hline V & Closed & \\
\hline W1 & Closed & \\
\hline W2 & Closed & \\
\hline W3 & Closed & \\
\hline Y & Closed & \\
\hline Z & Closed & \\
\hline A & Open & \\
\hline C & Open & \\
\hline D & Open & \\
\hline E & Open & \\
\hline F & Open & \\
\hline G & To collector & \\
\hline H1 & Open & \\
\hline H2 & Open & \\
\hline H3 & Closed & \\
\hline J1 & Closed & \\
\hline J2 & Closed & \\
\hline J3 & Closed & \\
\hline K1 & Open & \\
\hline M1 & Open & \\
\hline T & Closed & \\
\hline
\end{tabular}

5. Ship canisters after they have been released for shipment to PNNL for composition and isotopic ammonia ratio analysis.

6. Transmit Data Acquisition Control System (DACS) logs and copies of notebook records to the customer.

Note - Consult with the cognizant chemist and engineers if necessary to determine the method to remove solution from the extractor-mixing chamber.

7. Collect the remaining ${ }^{15} \mathrm{NH}_{4} \mathrm{OH}$ solution from the extractor mixing chamber by best available method in $1 \mathrm{~L}$ polybottles.

8. Record the estimated volume, time the sample is exposed to atmosphere before containing and characteristics of the solution removed in a controlled notebook.

9. Load samples out of the hot cell under HPT coverage using LO-160-101 as applicable.

10. Submit sample for ammonia analysis by Ion Selective Electrode (ISE).

11. At conclusion of ammonia analysis transmit data to the customer (see section 7.0 for reporting requirements).

12. Repeat steps from section 6.2.1 step 1 through section 6.2 .4 step 11 for a duplicate sample before proceeding to step 13 . 
HNF-5443, rev. 0 .

13. Prepare the RGS for Phase II testing.

\subsection{Phase II Testing}

\subsubsection{Solution Tests}

\subsubsection{Solution Preparation and Analysis}

Note - Solutions must be made fresh the day sample is to be run.

1. Make up a solution of $0.04 \mathrm{M}^{15} \mathrm{NH}_{4} \mathrm{OH}$ solution.

2. Allow solution to mix gently for 5 minutes.

3. Fill a $15 \mathrm{~mL}$ vial with a septum lid to the top with the ${ }^{15} \mathrm{NH}_{4} \mathrm{OH}$ solution.

4. Submit the $15 \mathrm{~mL}$ vial for ammonia analysis by ISE.

5. Make up a solution of $0.04 \mathrm{M}^{14} \mathrm{NH}_{4} \mathrm{OH}$ solution.

6. Fill a $15-\mathrm{ml}$ vial with a septum lid to the top with the ${ }^{14} \mathrm{NH}_{4} \mathrm{OH}$ solution.

7. Submit the 15-ml vial for ammonia analysis by ion selective electrode (ISE).

\subsubsection{Introduction of Simulant Solution to Extractor and Collection of Preliminary Samples}

Note - All system equilibration and system leak checks should be performed and documented prior to sample introduction according to the protocol established in LT-160-101 (appendix C) sections 10.1.2 and 10.2.2.

1. Ensure canisters are attached to ports $\mathrm{C} / \mathrm{D}$ and $\mathrm{H} 1 / \mathrm{J} 1$ and that the canister valves are open for evacuation.

2. Ensure the system temperature is at 10 to $12^{\circ} \mathrm{C}$ and record the date time, event, temperature and pressure in the notebook.

3. Set automatic data acquisition to 10 -second interval data log and record data file name in notebook.

4. Adjust pressure indicator zero offsets as necessary.

5. Close valve $\mathrm{T}$. 
6. Dispense approximately $100 \mathrm{ml}$ of the ${ }^{14} \mathrm{NH}_{4} \mathrm{OH}$ solution through valve $\mathrm{W} 2$ and then ensure valve $\mathrm{W} 2$ is closed.

7. Introduce $300 \mathrm{ml}$ of the ${ }^{14} \mathrm{NH}_{4} \mathrm{OH}$ solution to the RGS mixing chamber through valves $\mathrm{W} 1$ and $\mathrm{W} 3$ using the diluent reservoir.

8. Close valve $\mathrm{K} 1$.

9. Open valve $\mathrm{T}$.

10. Ensure the system temperature is at 10 to $12^{\circ} \mathrm{C}$.

Note - The motor speed of the extractor is $60 \mathrm{rpm}$ when the controller dial on the RGS console is dialed to 999.

11. Begin mixing solution by turning on the mixing motor and adjusting the motor speed to 60 rpm.

12. When system temperature and pressure stabilizes, record the date, time, event, temperature and pressure on the RGS processing worksheet and post in the controlled notebook.

13. Close valve $\mathrm{D}$ and record: sample/container $\mathrm{ID}$, temperature, and pressure in the notebook.

14. Close valve $F$ and ensure valve $G$ is turned to the collector side.

15. Perform the following steps 12 times initialing each step as performed:

\begin{tabular}{|l|l|l|l|l|l|l|l|l|l|l|l|l|}
\hline Step & 1 & 2 & 3 & 4 & 5 & 6 & 7 & 8 & 9 & 10 & 11 & 12 \\
\hline $\begin{array}{l}\text { a. Raise the mercury reservoir above } \\
\text { the 0-point. }\end{array}$ & & & & & & & & & & & & \\
\hline b. Open valve U. & & & & & & & & & & & & \\
\hline $\begin{array}{l}\text { c. Control flow of mercury with G, } \\
\text { sight glass and level of mercury } \\
\text { reservoir. }\end{array}$ & & & & & & & & & & & & \\
\hline $\begin{array}{l}\text { d. Lower mercury reservoir to bottom } \\
\text { of travel. }\end{array}$ & & & & & & & & & & & & \\
\hline $\begin{array}{l}\text { e. Record the system temperature and } \\
\text { pressure in notebook. }\end{array}$ & & & & & & & & & & & \\
\hline $\begin{array}{l}\text { f. Turn valve G to the extractor side } \\
\text { and wait until mercury completely } \\
\text { evacuates displacement bulb. }\end{array}$ & & & & & & & & & & & & \\
\hline g. Close valve U. & & & & & & & & & & & & \\
\hline h. Turn valve G to collector side. & & & & & & & & & & & & \\
\hline i. Repeat steps until completed. & & & & & & & & & & & & \\
\hline
\end{tabular}

16. Raise the mercury reservoir above 0 -point. 
HNF-5443, rev. 0

17. Open valve $U$ and control the flow of mercury to the sight glass with valve $G$ and height of the reservoir.

18. Lower the mercury reservoir to bottom of travel.

19. Record the temperature and pressure in the controlled notebook.

20. Close the valves on the gas sample canister at port $\mathrm{J} 1$ and $\mathrm{H} 1$.

21. Record the vapor sample canister ID, temperature and pressure in the notebook.

22. Stop data acquisition, close file, and copy file to a floppy disk.

23. Close valve $\mathrm{T}$.

24. Remove the canisters at ports $\mathrm{D}$ and $\mathrm{J} 1$.

25. Survey each vapor canister by swabbing in and around the connector tube and then surveying the swab for removable radioactive contamination.

26. Place new canisters at port $\mathrm{C} / \mathrm{D}, \mathrm{H} 1 / \mathrm{J} 1$ and $\mathrm{H} 2 / \mathrm{J} 2$ and ensure valves are open.

27. Ensure auxiliary port is plugged.

28. Turn valve $\mathrm{G}$ to the collector side

29. Open valve $\mathrm{K} 1$ and ensure the rotary vane pump is running and valve $\mathrm{M} 1$ is open.

30. Ensure the following valve configurations:

\begin{tabular}{|l|l|}
\hline Closed & $\mathrm{H} 3, \mathrm{J3}, \mathrm{K} 2, \mathrm{M} 2, \mathrm{~N} 1, \mathrm{~N} 2, \mathrm{~N} 3, \mathrm{~N} 4, \mathrm{R}, \mathrm{S}, \mathrm{T}, \mathrm{U}, \mathrm{V}, \mathrm{W} 1, \mathrm{~W} 2, \mathrm{~W} 3, \mathrm{Y}, \mathrm{Z}$ \\
\hline Open & $\mathrm{A}, \mathrm{B}, \mathrm{C}, \mathrm{D}, \mathrm{E}, \mathrm{F}, \mathrm{G}$ (to collector),H1,H2,H3,J1,J2,J3,K1,M1 \\
\hline
\end{tabular}

31. Turn heater/chiller unit off.

\subsubsection{Introduction of the Diluent to the Extractor}

1. Ensure the rotary vane pump is running.

2. Ensure the stirrer motor is rotating at $60 \mathrm{rpm}$.

3. Ensure the following valve configurations:

\begin{tabular}{|l|l|}
\hline Closed & $\mathrm{H} 3, \mathrm{~J} 3, \mathrm{~K} 2, \mathrm{M} 2, \mathrm{~N} 1, \mathrm{~N} 2, \mathrm{~N} 3, \mathrm{~N} 4, \mathrm{R}, \mathrm{S}, \mathrm{T}, \mathrm{U}, \mathrm{V}, \mathrm{W} 1, \mathrm{~W} 2, \mathrm{~W} 3, \mathrm{Y}, \mathrm{Z}$ \\
\hline Open & $\mathrm{A}, \mathrm{B}, \mathrm{C}, \mathrm{D}, \mathrm{E}, \mathrm{F}, \mathrm{G}$ (to collector),H1,H2,J1,J2,K1,M1 \\
\hline
\end{tabular}


HNF-5443, rev. 0

4. Dispense approximately $100 \mathrm{ml}$ diluent through valve $\mathrm{W} 2$ and then ensure valve $\mathrm{W} 2$ is closed.

5. Introduce $300 \mathrm{ml}$ of the ${ }^{15} \mathrm{NH}_{4} \mathrm{OH}$ solution to the $\mathrm{RGS}$ mixing chamber through valves $\mathrm{W} 1$ and $\mathrm{W} 3$ using the diluent reservoir.

6. Record date, time, event and temperature after the addition of diluent.

\subsubsection{Sampling at 24 hour, 4 days and 16 days from Test Initiation}

Note - The system is kept under ambient temperature and mixing conditions for the duration of the tests. Temperature is decreased to $10^{\circ} \mathrm{C}$ only during vapor pumping.

1. Ensure rotary vane pump is running.

2. Ensure valve $\mathrm{T}$ is closed and valves $\mathrm{K} 1$ and $\mathrm{M} 1$ are open.

3. Ensure canisters are attached at ports $\mathrm{H} 1 / \mathrm{J} 1$ and $\mathrm{H} 2 / \mathrm{J} 2$ and that the valves for these canisters are open.

4. Ensure the following valve configurations:

\begin{tabular}{|l|l|}
\hline Closed & $\mathrm{H} 3, \mathrm{~J} 3, \mathrm{~K} 2, \mathrm{M} 2, \mathrm{~N} 1, \mathrm{~N} 2, \mathrm{~N} 3, \mathrm{~N} 4, \mathrm{R}, \mathrm{S}, \mathrm{T}, \mathrm{U}, \mathrm{V}, \mathrm{W} 1, \mathrm{~W} 2, \mathrm{~W} 3, \mathrm{Y}, \mathrm{Z}$ \\
\hline Open & $\mathrm{A}, \mathrm{B}, \mathrm{C}, \mathrm{D}, \mathrm{E}, \mathrm{F}, \mathrm{G}$ (to collector),H1,H2,J1,J2,K1,M1 \\
\hline
\end{tabular}

5. Ensure stirrer motor is rotating at $60 \mathrm{rpm}$.

Note - No DACS data is obtained during equilibration times. Data is only taken during pumping and vapor extraction.

6. For the 24-hour sample, wait until 24 hours have elapsed from the time the ${ }^{15} \mathrm{NH}_{4} \mathrm{OH}$ solution was added before proceeding.

7. Ensure heater/chiller are on and controlling to $10^{\circ} \mathrm{C}$ and extractor temperature is $\sim 10^{\circ} \mathrm{C}$.

8. Set automatic data acquisition to 10 -second interval data $\log$ and record date file name in notebook.

9. Ensure system pressure is less than $0.01 \mathrm{kPa}$.

10. Adjust pressure indicator zero offsets as necessary.

11. Close valve $\mathrm{K} 1$. 
HNF-5443, rev. 0

12. Open valve T and wait until system's temperature and pressure stabilizes.

13. Record system temperature and pressure in the notebook.

14. Close valve $F$ and ensure $G$ is turned to the collector side.

15. Perform the following sequence 18 times and initial when completed:

\begin{tabular}{|c|c|c|c|c|c|c|c|c|c|c|c|c|c|c|c|c|c|c|}
\hline Step description: . & & 2 & 3 & 4 & 5 & 6 & 7 & 8 & 9 & $\begin{array}{l}1 \\
0 \\
\end{array}$ & $\begin{array}{l}1 \\
1\end{array}$ & $\begin{array}{l}1 \\
2 \\
\end{array}$ & $\begin{array}{l}1 \\
3 \\
\end{array}$ & $\begin{array}{l}1 \\
4\end{array}$ & $\begin{array}{l}1 \\
5 \\
\end{array}$ & $\begin{array}{l}1 \\
6 \\
\end{array}$ & & $\begin{array}{l}1 \\
8 \\
\end{array}$ \\
\hline $\begin{array}{l}\text { a: Raise mercury } \\
\text { reservoir above } 0 \text {-poin }\end{array}$ & & & & & & & & & & & & & & & & & & \\
\hline $\begin{array}{l}\text { b. Open valve } U \text { and } \\
\text { control height of merc } \\
\text { in sight glass with hei } \\
\text { of reservoir. }\end{array}$ & & & & & & & & & & & & & & & & & & \\
\hline $\begin{array}{l}\text { c. Lower mercury } \\
\text { reservoir to bottom of } \\
\text { travel. }\end{array}$ & & & & & & & & & & & & & & & & & & \\
\hline $\begin{array}{l}\text { d. Record system } \\
\text { pressure and temperatt } \\
\text { in notebook. }\end{array}$ & & & & & & & & & & & & & & & & & & \\
\hline $\begin{array}{l}\text { e. Turn valve } G \text { to } \\
\text { extractor side and wait } \\
\text { until mercury complet } \\
\text { evacuates the } \\
\text { displacement bulb. }\end{array}$ & & & & & & & & & & & & & & & & & & \\
\hline f. Close valve U. & & & & & & & & & & & & & & & & & & \\
\hline $\begin{array}{l}\text { g. Turn valve } \mathrm{G} \text { to } \\
\text { collector side. }\end{array}$ & & & & & & & & & & & & & & & & & & \\
\hline $\begin{array}{l}\text { h. Repeat cycles until } \\
\text { complete }\end{array}$ & & & & & & & & & & & & & & & & & & \\
\hline
\end{tabular}

16. Raise mercury reservoir above the 0 -point.

17. Open valve $U$ and control the flow of mercury to sight glass with valve $G$ and height of reservoir.

18. Lower mercury reservoir to bottom of travel.

19. Record system pressure and temperature in notebook.

20. Close valves $\mathrm{J} 1$ and $\mathrm{J} 2$ and $\mathrm{H} 1$ and $\mathrm{H} 2$ and record canister/sample $\mathrm{ID}$, pressure and temperature in the notebook. 
HNF-5443, rev. 0

21. Stop data acquisition, close file and copy data file to floppy disk.

Note - Canisters should be shipped to PNNL as soon as possible after collection, contact shipper concerning shipping the day samples are ready.

22. Remove canisters at ports $\mathrm{J} 1$ and $\mathrm{J} 2$.

23. After 3 days repeat steps 1 through 22 .

Note - Consult with the cognizant chemist and engineers if necessary to determine the method to remove solution from the extruder-mixing chamber.

24. After 12 days repeat steps 1 through 22 and collect the remaining $\mathrm{NH}_{4} \mathrm{OH}$ solution from the extruder mixing chamber by best available method.

25. Record the estimated volume and characteristics of the solution removed in a controlled notebook.

26. Ship remaining canisters after they have been released for shipment to PNNL for isotopic ammonia analysis.

27. Load liquid samples out of the hot cell under HPT coverage using LO-160-101 as applicable.

28. Submit sample for ammonia analysis by ISE.

29. At conclusion of ammonia analysis transmit data to the customer (see section 7.0 for reporting requirements).

30. Repeat section 6.3.1.1 step 1 through section 6.3.1.4 step 29 for a duplicate sample before proceeding to the next test.

Note - Consult the customer for guidance in completion of either section 6.2.2 Concentrated Solution Tests or 6.2.3 Solution/Solids Tests depending on data needs. Proceed with either section under written direction of the customer.

\subsubsection{Concentrated Solution Tests}

\subsubsection{Solution Preparation and Analysis}

Note - Solutions must be made fresh the day sample is to be run.

1. Make up a solution of $0.2 \mathrm{M}^{14} \mathrm{NH}_{4} \mathrm{OH}$ solution.

2. Allow solution to mix gently for 5 minutes.

3. Fill a $15-\mathrm{ml}$ vial with a septum lid to the top with the ${ }^{15} \mathrm{NH}_{4} \mathrm{OH}$ solution. 


\section{HNF-5443, rev. 0}

4. Submit the $15-\mathrm{ml}$ vial for ammonia analysis by ion selective electrode (ISE).

5. Make up a solution of $0.04 \mathrm{M}^{15} \mathrm{NH}_{4} \mathrm{OH}$ solution.

6. Fill a $15-\mathrm{ml}$ vial with a septum lid to the top with the ${ }^{15} \mathrm{NH}_{4} \mathrm{OH}$ solution.

7. Submit the $15-\mathrm{ml}$ vial for ammonia analysis by ion selective electrode (ISE).

\subsubsection{Introduction of Simulant Solution to Extractor and Collection of Preliminary Samples}

Note - All system equilibration and system leak checks should be performed and documented prior to sample introduction according to the protocol established in LT-160-101 (appendix C) sections 10.1.2 and 10.2.2.

1. Ensure canisters are attached to ports $\mathrm{C} / \mathrm{D}$ and $\mathrm{H} 1 / \mathrm{J} 1$ and that the canister valves are open for evacuation.

2. Ensure the system temperature is at 10 to $12^{\circ} \mathrm{C}$ and record the date time, event, temperature and pressure in the notebook.

3. Set automatic data acquisition to 10 -second interval data log and record data file name in notebook.

4. Adjust pressure indicator zero offsets as necessary.

5. Close valve T.

6. Dispense approximately $100 \mathrm{ml}^{14} \mathrm{NH}_{4} \mathrm{OH}$ solution through valve $\mathrm{W} 2$ and then ensure valve W2 is closed.

7. Introduce $300 \mathrm{ml}$ of the ${ }^{14} \mathrm{NH}_{4} \mathrm{OH}$ solution to the RGS mixing chamber through valves $\mathrm{W} 1$ and $\mathrm{W} 3$ using the diluent reservoir.

8. Close valve $\mathrm{K} 1$.

9. Open valve T.

10. Ensure the system temperature is at 10 to $12^{\circ} \mathrm{C}$.

Note - The motor speed of the extractor is $60 \mathrm{rpm}$ when the controller dial on the RGS console is dialed to 999.

11. Begin mixing solution by turning on the mixing motor and adjusting the motor speed to 60 rpm. 
12. When system temperature and pressure stabilizes, record the date, time, event, temperature and pressure on the RGS processing worksheet and post in the controlled notebook.

13. Close valve D and record: sample/container ID, temperature, and pressure in the notebook.

14. Close valve $\mathrm{F}$ and ensure valve $\mathrm{G}$ is turned to the collector side.

15. Perform the following steps 12 times initialing each step as performed:

\begin{tabular}{|c|c|c|c|c|c|c|c|c|c|c|c|c|c|}
\hline \multirow{2}{*}{\multicolumn{14}{|c|}{$\begin{array}{l}\text { Step } \\
\text { a. Raise the mercury reservoir above } \\
\text { the } 0 \text {-point. }\end{array}$}} \\
\hline & & & & & & & & & & & & & \\
\hline b. Open valve U. & & & & & & & & & & & & & \\
\hline $\begin{array}{l}\text { c. Control flow of mercury with } \mathrm{G} \text {, } \\
\text { sight glass and level of mercury } \\
\text { reservoir. }\end{array}$ & & & & & & & & & & & & & \\
\hline $\begin{array}{l}\text { d. Lower mercury reservoir to bottom } \\
\text { of travel. }\end{array}$ & & & & & & & & & & & & & \\
\hline $\begin{array}{l}\text { e. Record the system temperature and } \\
\text { pressure in notebook. }\end{array}$ & & & & & & & & & & & & & \\
\hline $\begin{array}{l}\text { f. Turn valve } \mathrm{G} \text { to the extractor side } \\
\text { and wait until mercury completely } \\
\text { evacuates displacement bulb. }\end{array}$ & & & & & & & & & & & & & \\
\hline g. Close valve U. & & & & & & & & & & & & & \\
\hline h. Turn valve $\mathrm{G}$ to collector side. & & & & & & & & & & & & & \\
\hline i. Repeat steps until completed. & & & & & & & & & & & & & \\
\hline
\end{tabular}

16. Raise the mercury reservoir above 0-point.

17. Open valve $U$ and control the flow of mercury to the sight glass with valve $G$ and height of the reservoir.

18. Lower the mercury reservoir to bottom of travel.

19. Record the temperature and pressure in the controlled notebook.

20. Close the valves on the gas sample canister at port $\mathrm{J} 1$ and $\mathrm{H} 1$.

21. Record the vapor sample canister $\mathbb{D}$, temperature and pressure in the notebook.

22. Stop data acquisition, close file, and copy file to a floppy disk.

23. Close valve $\mathrm{T}$.

24. Remove the canisters at ports D and J1. 
25. Survey each vapor canister by swabbing in and around the connector tube and then surveying the swab for removable radioactive contamination.

26. Place new canisters at port $\mathrm{C} / \mathrm{D}, \mathrm{H} 1 / \mathrm{J} 1$ and $\mathrm{H} 2 / \mathrm{J} 2$ and ensure valves are open.

27. Ensure auxiliary port is plugged.

28. Turn valve $G$ to the collector side

29. Open valve $\mathrm{K} 1$ and ensure the rotary vane pump is running and valve $\mathrm{M} 1$ is open.

30. Ensure the following valve configurations:

\begin{tabular}{|l|l|}
\hline Closed & $\mathrm{H} 3, \mathrm{~J} 3, \mathrm{~K} 2, \mathrm{M} 2, \mathrm{~N} 1, \mathrm{~N} 2, \mathrm{~N} 3, \mathrm{~N} 4, \mathrm{R}, \mathrm{S}, \mathrm{T}, \mathrm{U}, \mathrm{V}, \mathrm{W} 1, \mathrm{~W} 2, \mathrm{~W} 3, \mathrm{Y}, \mathrm{Z}$ \\
\hline Open & $\mathrm{A}, \mathrm{B}, \mathrm{C}, \mathrm{D}, \mathrm{E}, \mathrm{F}, \mathrm{G}$ (to collector),H1,H2,H3,J1,J2,J3,K1,M1 \\
\hline
\end{tabular}

31. Turn heater/chiller unit off.

\subsubsection{Introduction of the Diluent to the Extractor}

1. Ensure the rotary vane pump is running.

7. Ensure the stirrer motor is rotating at $60 \mathrm{rpm}$.

8. Ensure the following valve configurations:

\begin{tabular}{|l|l|}
\hline Closed & $\mathrm{H} 3, \mathrm{~J} 3, \mathrm{~K} 2, \mathrm{M} 2, \mathrm{~N} 1, \mathrm{~N} 2, \mathrm{~N} 3, \mathrm{~N} 4, \mathrm{R}, \mathrm{S}, \mathrm{T}, \mathrm{U}, \mathrm{V}, \mathrm{W} 1, \mathrm{~W} 2, \mathrm{~W} 3, \mathrm{Y}, \mathrm{Z}$ \\
\hline Open & $\mathrm{A}, \mathrm{B}, \mathrm{C}, \mathrm{D}, \mathrm{E}, \mathrm{F}, \mathrm{G}$ (to collector),H1,H2,J1,J2,K1,M1 \\
\hline
\end{tabular}

9. Dispense approximately $100 \mathrm{ml}^{15} \mathrm{NH}_{4} \mathrm{OH}$ solution diluent through valve $\mathrm{W} 2$ and then ensure valve W2 is closed.

10. Introduce $300 \mathrm{ml}$ of the ${ }^{15} \mathrm{NH}_{4} \mathrm{OH}$ solution to the RGS mixing chamber through valves W1 and $\mathrm{W} 3$ using the diluent reservoir.

11. Record date, time, event and temperature after the addition of diluent.

\subsubsection{Sampling at 24 hour, 4 days and 16 days from Test Initiation}

Note - The system is kept under ambient temperature and mixing conditions for the duration of the tests. Temperature is decreased to $10^{\circ} \mathrm{C}$ only during vapor pumping.

1. Ensure rotary vane pump is running. 
HNF-5443, rev. 0

2. Ensure valve $\mathrm{T}$ is closed and valves $\mathrm{K} 1$ and $\mathrm{M} 1$ are open.

3. Ensure canisters are attached at ports $\mathrm{H} 1 / \mathrm{J} 1$ and $\mathrm{H} 2 / \mathrm{J} 2$ and that the valves for these canisters are open.

4. Ensure the following valve configurations:

\begin{tabular}{|l|l|}
\hline Closed & $\mathrm{H} 3, \mathrm{~J} 3, \mathrm{~K} 2, \mathrm{M} 2, \mathrm{~N} 1, \mathrm{~N} 2, \mathrm{~N} 3, \mathrm{~N} 4, \mathrm{R}, \mathrm{S}, \mathrm{T}, \mathrm{U}, \mathrm{V}, \mathrm{W} 1, \mathrm{~W} 2, \mathrm{~W} 3, \mathrm{Y}, \mathrm{Z}$ \\
\hline Open & $\mathrm{A}, \mathrm{B}, \mathrm{C}, \mathrm{D}, \mathrm{E}, \mathrm{F}, \mathrm{G}$ (to collector),H1,H2,J1,J2,K1,M1 \\
\hline
\end{tabular}

5. Ensure stirrer motor is rotating at $60 \mathrm{rpm}$.

Note - No DACS data is obtained during equilibration times. Data is only taken during pumping and vapor extraction.

6. For the 24-hour sample, wait until 24 hours have elapsed from the time of addition of the ${ }^{15} \mathrm{NH}_{4} \mathrm{OH}$ solution diluent before proceeding.

7. Ensure heater/chiller are on and controlling to $10^{\circ} \mathrm{C}$ and extractor temperature is $\sim 10^{\circ} \mathrm{C}$.

8. Set automatic data acquisition to 10 -second interval data log and record date file name in notebook.

9. Ensure system pressure is less than $0.01 \mathrm{kPa}$.

10. Adjust pressure indicator zero offsets as necessary.

11. Close valve $\mathrm{K} 1$.

12. Open valve $\mathrm{T}$ and wait until system's temperature and pressure stabilizes.

13. Record system temperature and pressure in the notebook.

14. Close valve $F$ and ensure $G$ is turned to the collector side.

15. Perform the following sequence 18 times and initial each step when completed:

\begin{tabular}{|l|l|l|l|l|l|l|l|l|l|l|l|l|l|l|l|l|l|l|}
\hline Step description: & 1 & 2 & 3 & 4 & 5 & 6 & 7 & 8 & 9 & 1 & 1 & 1 & 1 & 1 & 1 & 1 & 1 & 1 \\
\hline $\begin{array}{l}\text { a. Raise mercury } \\
\text { reservoir above 0-point. }\end{array}$ & & & & & & & & & & & & & & & & & & \\
\hline $\begin{array}{l}\text { b. Open valve U and } \\
\text { control height of mercury } \\
\text { in sight glass with height } \\
\text { of reservoir. }\end{array}$ & & & & & & & & & & & & & & & & & & \\
\hline
\end{tabular}


HNF-5443, rev. 0

\begin{tabular}{|c|c|c|c|c|c|c|c|c|c|c|c|c|c|c|c|c|c|c|}
\hline Step description: & 1 & 2 & 3 & 4 & 5 & 6 & 7 & 8 & 9 & $\begin{array}{l}1 \\
0\end{array}$ & $\begin{array}{l}1 \\
1\end{array}$ & $\begin{array}{l}1 \\
2\end{array}$ & \begin{tabular}{|l|}
1 \\
3
\end{tabular} & \begin{tabular}{|l|}
1 \\
4
\end{tabular} & \begin{tabular}{l|}
1 \\
5
\end{tabular} & $\begin{array}{l}1 \\
6\end{array}$ & & $\begin{array}{l}1 \\
8\end{array}$ \\
\hline $\begin{array}{l}\text { c. Lower mercury } \\
\text { reservoir to bottom of } \\
\text { travel. }\end{array}$ & & & & & & & & & & & & & & & & & & \\
\hline $\begin{array}{l}\text { d. Record system } \\
\text { pressure and temperatl } \\
\text { in notebook. }\end{array}$ & & & & & & & & & & & & & & & & & & \\
\hline $\begin{array}{l}\text { e. Turn valve } G \text { to } \\
\text { extractor side and wait } \\
\text { until mercury complet } \\
\text { evacuates the } \\
\text { displacement bulb. }\end{array}$ & & & & & & & & & & & & & & & & & & \\
\hline f. Close valve $U$. & & & & & & & & & & & & & & & & & & \\
\hline $\begin{array}{l}\text { g. Turn valve } G \text { to } \\
\text { collector side. }\end{array}$ & & & & & & & & & & & & & & & & & & \\
\hline $\begin{array}{l}\text { h. Repeat cycles until } \\
\text { complete }\end{array}$ & & & & & & & & & & & & & & & & & & \\
\hline
\end{tabular}

16. Raise mercury reservoir above the 0 -point.

17. Open valve $U$ and control the flow of mercury to sight glass with valve $G$ and height of reservoir.

18. Lower mercury reservoir to bottom of travel.

19. Record system pressure and temperature in notebook.

20. Close valves $\mathrm{J} 1$ and $\mathrm{J} 2$ and $\mathrm{H} 1$ and $\mathrm{H} 2$ and record canister/sample $\mathrm{ID}$, pressure and temperature in the notebook.

21. Stop data acquisition, close file and copy data file to floppy disk.

Note - Canisters should be shipped to PNNL as soon as possible after collection, contact shipper concerning shipping the day samples are ready.

22. Remove canisters at ports $\mathrm{J} 1$ and $\mathrm{J} 2$.

23. After 3 days repeat steps 1 through 22 .

Note - Consult with the cognizant chemist and engineers if necessary to determine the method to remove solution from the extruder-mixing chamber.

24. After 12 days repeat steps 1 through 22 and collect the remaining $\mathrm{NH}_{4} \mathrm{OH}$ solution from the extruder mixing chamber by best available method. 
HNF-5443, rev. 0

25. Record the estimated volume and characteristics of the solution removed in a controlled notebook.

26. Ship remaining canisters after they have been released for shipment to PNNL for isotopic ammonia analysis.

27. Load liquid samples out of the hot cell under HPT coverage using LO-160-101 as applicable.

28. Submit sample for ammonia analysis by ISE.

29. At conclusion of ammonia analysis transmit data to the customer (see section 7.0 for reporting requirements).

30. Repeat section 6.3.2.1 step 1 through section 6.3.2.4 step 29 for a duplicate sample before proceeding to the next test.

\subsubsection{Solution/Solids Tests}

\subsubsection{Solution Preparation and Analysis}

1. Make up a solution of $0.04 \mathrm{M}^{14} \mathrm{NH}_{4} \mathrm{OH}$ solution

2. Allow solutions to mix gently for 5 minutes.

3. Fill a $15 \mathrm{~mL}$ vial with a septum lid to the top with the ${ }^{14} \mathrm{NH}_{4} \mathrm{OH}$ solution.

4. Submit the $15 \mathrm{~mL}$ vial for ammonia analysis by ion selective electrode (ISE).

5. Make up a solution of $0.04 \mathrm{M}^{15} \mathrm{NH}_{4} \mathrm{OH}$ solution.

6. Fill a $15 \mathrm{~mL}$ vial with a septum lid to the top with the ${ }^{15} \mathrm{NH}_{4} \mathrm{OH}$ solution.

7. Submit the $15 \mathrm{~mL}$ vial for ammonia analysis by ion selective electrode (ISE).

\subsubsection{Introduction of Simulant Solid and Solution to Extractor}

Note - All system equilibration and system leak checks should be performed and documented prior to sample introduction according to the protocol established in LT-160-101 (appendix C) sections 10.2.1 and 10.2.2.

1. Ensure canisters are attached to ports $\mathrm{C} / \mathrm{D}$ and $\mathrm{HI} / \mathrm{J} 1$ and that the canister valves are open for evacuation.

2. Ensure the system temperature is at 10 to $12^{\circ} \mathrm{C}$ and record the date time, event, temperature and pressure in the notebook. 
HNF-5443, rev. 0

3. Set automatic data acquisition to 10 -second interval data log and record data file name in notebook.

4. Adjust pressure indicator zero offsets as necessary.

5. Close valve $\mathrm{T}$.

Note - Solid sample shall be loaded into the hot cell using LO-160-101 under HPT supervision before proceeding.

6. Weigh the equivalent of $120 \mathrm{~mL}$ of sea sand using the density provided by the manufacturer into a tube to be placed in the extruder.

7. Load the sea sand into the extractor by best available method.

Note - All system equilibration and leak checks must be performed after solids introduction according to the protocol established in LT-160-101 sections 10.2.1 and 10.2.1.

8. Open valve $\mathrm{T}$ slowly to evacuate the extractor after addition of the solids.

9. Close valve $\mathrm{T}$.

10. Dispense approximately $100 \mathrm{ml}^{14} \mathrm{NH}_{4} \mathrm{OH}$ solution through valve $\mathrm{W} 2$ and then ensure valve W2 is closed.

11. Introduce $180 \mathrm{~mL}$ of the ${ }^{14} \mathrm{NH}_{4} \mathrm{OH}$ solution to the $\mathrm{RGS}$ mixing chamber through valves $\mathrm{W} 1$ and $\mathrm{W} 3$ using the diluent reservoir.

12. Close valve $\mathrm{K} 1$.

13. Open valve T.

14. Ensure the system temperature is at 10 to $12^{\circ} \mathrm{C}$.

Note - The motor speed of the extractor is $60 \mathrm{rpm}$ when the controller dial on the RGS console is dialed to 999 .

15. Begin mixing solution by turning on the mixing motor and adjusting the motor speed to 60 rpm.

16. When system temperature and pressure stabilizes, record the date, time, event, temperature and pressure on the RGS processing worksheet and post in the controlled notebook.

17. Close valve $\mathrm{D}$ and record: sample/container $\mathrm{D}$, temperature, and pressure in the notebook. 
18. Close valve $F$ and ensure valve $G$ is turned to the collector side.

19. Perform the following steps 12 times initialing each step as performed:

\begin{tabular}{|l|l|l|l|l|l|l|l|l|l|l|l|l|}
\hline Step & 1 & 2 & 3 & 4 & 5 & 6 & 7 & 8 & 9 & 10 & 11 & 12 \\
\hline $\begin{array}{l}\text { a. Raise the mercury reservoir above } \\
\text { the 0-point. }\end{array}$ & & & & & & & & & & & & \\
\hline b. Open valve U. & & & & & & & & & & & & \\
\hline $\begin{array}{l}\text { c. Control flow of mercury with G, } \\
\text { sight glass and level of mercury } \\
\text { reservoir. }\end{array}$ & & & & & & & & & & & & \\
\hline $\begin{array}{l}\text { d. Lower mercury reservoir to bottom } \\
\text { of travel. }\end{array}$ & & & & & & & & & & & \\
\hline $\begin{array}{l}\text { e. Record the system temperature and } \\
\text { pressure in notebook. }\end{array}$ & & & & & & & & & & & \\
\hline $\begin{array}{l}\text { f. Turn valve G to the extractor side } \\
\text { and wait until mercury completely } \\
\text { evacuates displacement bulb. }\end{array}$ & & & & & & & & & & & & \\
\hline g. Close valve U. & & & & & & & & & & & & \\
\hline h. Turn valve G to collector side. & & & & & & & & & & & & \\
\hline i. Repeat steps until completed. & & & & & & & & & & & \\
\hline
\end{tabular}

20. Raise the mercury reservoir above 0 -point.

21. Open valve $U$ and control the flow of mercury to the sight glass with valve $G$ and height of the reservoir.

22. Lower the mercury reservoir to bottom of travel.

23. Record the temperature and pressure in the controlled notebook.

24. Close the valves on the gas sample canister at port $\mathrm{J} 1$ and $\mathrm{H} 1$.

25. Record the vapor sample canister ID, temperature and pressure in the notebook.

26. Stop data acquisition, close file, and copy file to a floppy disk.

27. Close valve $T$.

28. Remove the canisters at ports $\mathrm{D}$ and $\mathrm{J} 1$.

29. Survey each vapor canister by swabbing in and around the connector tube and then surveying the swab for removable radioactive contamination.

30. Place new canisters at port $\mathrm{C} / \mathrm{D}, \mathrm{H} 1 / \mathrm{J} 1$ and $\mathrm{H} 2 / \mathrm{J} 2$ and ensure valves are open. 
31. Ensure auxiliary port is plugged.

32. Turn valve $\mathrm{G}$ to the collector side

33. Open valve $\mathrm{K} 1$ and ensure the rotary vane pump is running and valve $\mathrm{M} 1$ is open.

34. Ensure the following valve configurations:

\begin{tabular}{|l|l|}
\hline Closed & $\mathrm{H} 3, \mathrm{~J} 3, \mathrm{~K} 2, \mathrm{M} 2, \mathrm{~N} 1, \mathrm{~N} 2, \mathrm{~N} 3, \mathrm{~N} 4, \mathrm{R}, \mathrm{S}, \mathrm{T}, \mathrm{U}, \mathrm{V}, \mathrm{W} 1, \mathrm{~W} 2, \mathrm{~W} 3, \mathrm{Y}, \mathrm{Z}$ \\
\hline Open & A,B,C,D,E,F, G(to collector),H1,H2,H3,J1,J2,K1,M1 \\
\hline
\end{tabular}

35. Turn heater/chiller unit off.

\subsubsection{Introduction of the Diluent to the Extractor}

1. Ensure the rotary vane pump is running.

2. Ensure the stirrer motor is rotating at $60 \mathrm{rpm}$.

3. Ensure the following valve configurations:

\begin{tabular}{|l|l|}
\hline Closed & $\mathrm{H} 3, \mathrm{~J} 3, \mathrm{~K} 2, \mathrm{M} 2, \mathrm{~N} 1, \mathrm{~N} 2, \mathrm{~N} 3, \mathrm{~N} 4, \mathrm{R}, \mathrm{S}, \mathrm{T}, \mathrm{U}, \mathrm{V}, \mathrm{W} 1, \mathrm{~W} 2, \mathrm{~W} 3, \mathrm{Y}, \mathrm{Z}$ \\
\hline Open & $\mathrm{A}, \mathrm{B}, \mathrm{C}, \mathrm{D}, \mathrm{E}, \mathrm{F}, \mathrm{G}$ (to collector),H1,H2,J1,J2,K1,M1 \\
\hline
\end{tabular}

4. Dispense approximately $100 \mathrm{ml}^{15} \mathrm{NH}_{4} \mathrm{OH}$ solution diluent through valve $\mathrm{W} 2$ and then ensure valve $\mathrm{W} 2$ is closed.

5. Introduce $300 \mathrm{ml}$ of the ${ }^{15} \mathrm{NH}_{4} \mathrm{OH}$ solution to the RGS mixing chamber through valves $\mathrm{W} 1$ and $\mathrm{W} 3$ using the diluent reservoir.

6. Record date, time, event and temperature after the addition of diluent.

\subsubsection{Sampling at 24 hour, 4 days and 16 days from Test Initiation}
Note - The system is kept under ambient temperature and mixing conditions for the duration of the tests. Temperature is decreased to $10^{\circ} \mathrm{C}$ only during vapor pumping.

1. Ensure rotary vane pump is running.

2. Ensure valve $\mathrm{T}$ is closed and valves $\mathrm{K} 1$ and $\mathrm{M} 1$ are open.

3. Ensure canisters are attached at ports $\mathrm{H} 1 / \mathrm{J} 1$ and $\mathrm{H} 2 / \mathrm{J} 2$ and that the valves for these canisters are open.

4. Ensure the following valve configurations: 


\begin{tabular}{|l|l|}
\hline Closed & $\mathrm{H} 3, \mathrm{J3}, \mathrm{K} 2, \mathrm{M} 2, \mathrm{~N} 1, \mathrm{~N} 2, \mathrm{~N} 3, \mathrm{~N} 4, \mathrm{R}, \mathrm{S}, \mathrm{T}, \mathrm{U}, \mathrm{V}, \mathrm{W} 1, \mathrm{~W} 2, \mathrm{~W} 3, \mathrm{Y}, \mathrm{Z}$ \\
\hline Open & $\mathrm{A}, \mathrm{B}, \mathrm{C}, \mathrm{D}, \mathrm{E}, \mathrm{F}, \mathrm{G}$ (to collector),H1,H2,J1,J2,K1,M1 \\
\hline
\end{tabular}

5. Ensure stirrer motor is rotating at $60 \mathrm{rpm}$.

Note - No DACS data is obtained during equilibration times. Data is only taken during pumping and vapor extraction.

6. For the 24-hour sample, wait until 24 hours have elapsed from the addition of ${ }^{15} \mathrm{NH}_{4} \mathrm{OH}$ solution diluent before proceeding.

7. Ensure heater/chiller are on and controlling to $10^{\circ} \mathrm{C}$ and extractor temperature is $\sim 10^{\circ} \mathrm{C}$.

8. Set automatic data acquisition to 10 -second interval data $\log$ and record date file name in notebook.

9. Ensure system pressure is less than $0.01 \mathrm{kPa}$.

10. Adjust pressure indicator zero offsets as necessary.

11. Close valve $\mathrm{K} 1$.

12. Open valve $T$ and wait until system's temperature and pressure stabilizes.

13. Record system temperature and pressure in the notebook.

14. Close valve $F$ and ensure $G$ is turned to the collector side.

- 15. Perform the following sequence 18 times and initial when completed:

\begin{tabular}{|c|c|c|c|c|c|c|c|c|c|c|c|c|c|c|c|c|c|c|c|c|}
\hline Step description: & 1 & 2 & 3 & 4 & 5 & 6 & 7 & 8 & 9 & 1 & & 1 & $\begin{array}{l}1 \\
2 \\
\end{array}$ & $\begin{array}{l}1 \\
3\end{array}$ & & $\begin{array}{l}1 \\
5\end{array}$ & & & & \begin{tabular}{|l|}
1 \\
8 \\
\end{tabular} \\
\hline $\begin{array}{l}\text { a. Raise mercury } \\
\text { reservoir above 0-point. }\end{array}$ & & & & & & & & & & & & & & & & & & & & \\
\hline $\begin{array}{l}\text { b. Open valve U and } \\
\text { control height of mercury } \\
\text { in sight glass with height } \\
\text { of reservoir. }\end{array}$ & & & & & & & & & & & & & & & & & & & & \\
\hline $\begin{array}{l}\text { c. Lower mercury } \\
\text { reservoir to bottom of } \\
\text { travel. }\end{array}$ & & & & & & & & & & & & & & & & & & & & \\
\hline $\begin{array}{l}\text { d. Record system } \\
\text { pressure and temperature } \\
\text { in notebook. }\end{array}$ & & & & & & & & & & & & & & & & & & & & \\
\hline e. Turn valve $\mathrm{G}$ to & & & & & & & & & & & & & & & & & & & & \\
\hline
\end{tabular}




\begin{tabular}{|l|l|l|l|l|l|l|l|l|l|l|l|l|l|l|l|l|l|l|}
\hline Step description: & 1 & 2 & 3 & 4 & 5 & 6 & 7 & 8 & 9 & 1 & 1 & 1 & 1 & 1 & 1 & 1 & 1 & 1 \\
\hline $\begin{array}{l}\text { extractor side and wait } \\
\text { until mercury completely } \\
\text { evacuates the } \\
\text { displacement bulb. }\end{array}$ & & & & & & & & & & & & & & & & & & \\
\hline f. Close valve U. & & & & & & & & & & & & & & & & & & \\
\hline $\begin{array}{l}\text { g. Turn valve G to } \\
\text { collector side. }\end{array}$ & & & & & & & & & & & & & & & & & \\
\hline $\begin{array}{l}\text { h. Repeat cycles until } \\
\text { complete }\end{array}$ & & & & & & & & & & & & & & & & & & \\
\hline
\end{tabular}

16. Raise mercury reservoir above the 0-point.

17. Open valve $U$ and control the flow of mercury to sight glass with valve $G$ and height of reservoir.

18. Lower mercury reservoir to bottom of travel.

19. Record system pressure and temperature in notebook.

20. Close valves $\mathrm{J} 1$ and $\mathrm{J} 2$ and $\mathrm{H} 1$ and $\mathrm{H} 2$ and record canister/sample $\mathrm{ID}$, pressure and temperature in the notebook.

21. Stop data acquisition, close file and copy data file to floppy disk.

Note - Canisters should be shipped to PNNL as soon as possible after collection, contact shipper concerning shipping the day samples are ready.

22. Remove canisters at ports $\mathrm{J} 1$ and $\mathrm{J} 2$.

23. After 3 days repeat steps 1 through 22 .

Note - Consult with the cognizant chemist and engineers if necessary to determine the method to remove solution from the extruder-mixing chamber.

24. After 12 days repeat steps 1 through 22 and collect the remaining $\mathrm{NH}_{4} \mathrm{OH}$ solution from the extruder mixing chamber by best available method.

25. Record the estimated volume and characteristics of the solution removed in a controlled notebook.

26. Ship remaining canisters after they have been released for shipment to PNNL for isotopic ammonia analysis.

27. Load liquid samples out of the hot cell under HPT coverage using LO-160-101 as applicable. 
HNF-5443, rev. 0

28. Submit sample for ammonia analysis by ISE.

29. At conclusion of ammonia analysis transmit data to the customer (see section 7.0 for reporting requirements).

30. Repeat section 6.3.2.1 step 1 through section 6.3.2.4 step 29 for a duplicate sample before proceeding to the next test.

\subsection{REPORTING REQUIREMENTS}

At the completion of each sample run, the following shall be provided to the customer: a set of DACS data obtained in accordance with LT-106-101, copies of notebook observations transmitted to the customer via facsimile, and any analytical results from sample analyses as validated data from the laboratory information management system, LabCore. No formal report or data package will be transmitted.

\subsection{SCHEDULE FOR TESTS}

December 15 - complete processing and approval of test plan

\section{Phase I Solution Tests:}

Jan. 13 - Run \#1 set up

Jan. 14 -24-hour sample obtained

Jan. 17 - Prepare for Run \#2

Jan. 19 -24-hour sample obtained

Jan 24-28 - First shipment of RGS samples to PNNL for ammonia analyses

Shipment to include: 4-24-hour phase I sample canisters

4-initial and 24-hour phase II run \#1 test sample canisters

Submit to 222-S analytical for analysis: 2-initial aqueous samples of $0.04 \mathrm{M}$

$\mathrm{NH}_{4} \mathrm{OH}$ solution for $\mathrm{NH}_{3}$ by ISE

2-resultant aqueous samples of $0.04 \mathrm{M}$

$\mathrm{NH}_{4} \mathrm{OH}$ solution (after extraction) for

$\mathrm{NH}_{3}$ by ISE

\section{Phase II Solution Tests}

Jan. 24 - Run set up \#1

Jan. 25 -24-hour sample obtained

Jan. 28 - 4-day sample obtained 
Feb. 9 - 16-day sample obtained

Feb. 10 - Run \#2 set up

Feb. 11 -24-hour sample obtained

Feb. 7-11 - Second shipment of RGS samples to PNNL for ammonia analyses Shipment to include: 2-4 day phase II run \#1 sample canisters

2- 16-day phase II run \#1 sample canisters Submit to 222-S analytical for analysis: 4-initial aqueous samples of $0.04 \mathrm{M}$ $\mathrm{NH}_{4} \mathrm{OH}$ solution for $\mathrm{NH}_{3}$ by ISE 1-resultant aqueous samples of $0.04 \mathrm{M}$ $\mathrm{NH}_{4} \mathrm{OH}$ solution (after extraction) for

Phase II Solution Tests $\mathrm{NH}_{3}$ by ISE

Feb. 14 - 4-day sample obtained

Feb. 26 (Saturday) - 16-day sample

Feb. 26- Mar.2 - third shipment of RGS samples to PNNL for ammonia analyses

Shipment to include: 4- initial and 24-hour phase II run \#2 sample canisters

2- 4-day phase II run \#2 sample canisters

2- 16-day phase II run \#2 sample canisters

Submit to 222-S analytical for analysis: 2-initial aqueous samples of $0.04 \mathrm{M}$

$\mathrm{NH}_{4} \mathrm{OH}$ solution for $\mathrm{NH}_{3}$ by ISE

1-resultant aqueous samples of $\mathrm{NH}_{4} \mathrm{OH}$ solution (after extraction) for $\mathrm{NH}_{3}$ by ISE

\section{Phase II solution/solids tests:}

Feb. 28- Run \#1 set up

Feb. 29-24-hour sample

Mar. 3 - 4-day sample

Mar. 15 - 16-day sample

Mar. 20 - Run \#2 set up

Mar.20 -24 - fourth shipment of RGS samples to PNNL for ammonia analyses

Shipment to include: 4- initial and 24-hour phase II run \#1 sample canisters 
HNF-5443, rev. 0

2- 4-day phase II run \#1 sample canisters

2- 16-day phase II run \#1 sample canisters

Submit to 222-S analytical for analysis: 2-initial aqueous samples of 0.04 or $0.2 \mathrm{M}$

$\mathrm{NH}_{4} \mathrm{OH}$ solution for $\mathrm{NH}_{3}$ by ISE

1-resultant aqueous samples of $\mathrm{NH}_{4} \mathrm{OH}$

solution (after extraction) for $\mathrm{NH}_{3}$ by

ISE

Mar. 21 - 24-hour sample

Mar. 24 - 4-day sample

April 5 - 16-day sample

April 10-14 - Fifth shipment of RGS samples to PNNL for ammonia analyses

Shipment to include: 4 - initial and 24-hour phase II run \#1 sample canisters

2- 4-day phase II run \#1 sample canisters

2- 16-day phase II run \#1 sample canisters

Submit to 222-S analytical for analysis: 2-initial aqueous samples of 0.04 or $0.2 \mathrm{M}$

$\mathrm{NH}_{4} \mathrm{OH}$ solution for $\mathrm{NH}_{3}$ by $\mathrm{ISE}$

1-resultant aqueous samples of $\mathrm{NH}_{4} \mathrm{OH}$ solution (after extraction) for $\mathrm{NH}_{3}$ by

ISE 
HNF-5443, rev. 0

Appendix A

LO-100-151

Segregate and Manage Solid

Laboratory Wastes 


\section{WASTE MANAGEMENT LABORATORY \\ SEGREGATE AND MANAGE SOLID LABORATORY WASTES \\ LO-100-151}

REV/CHANGE NO. E-4

Printed: November 12, 1999 2:34pm

PAGE 1 of 38

EFFECTIVE DATE 11/16/99

\section{APPROVAL DESIGNATOR ES}

Procedure Use Level REFERENCE

TABLE OF CONTENTS

PAGE

1.0 PURPOSE AND SCOPE

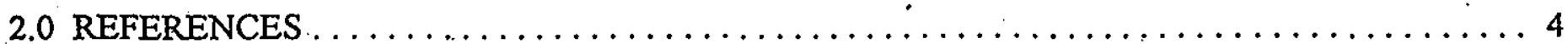

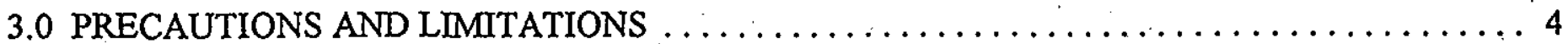

3.1 Solid Low Level Radioactive Waste $\ldots \ldots \ldots \ldots \ldots \ldots \ldots \ldots \ldots \ldots \ldots \ldots$

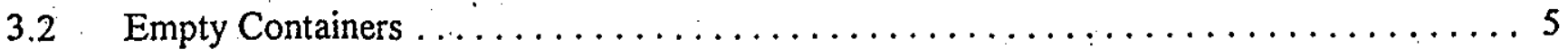

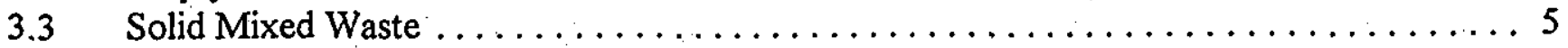

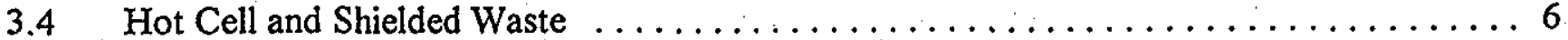

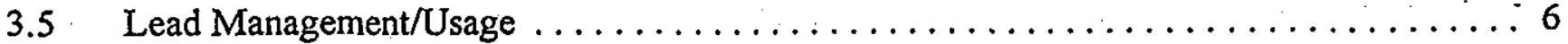

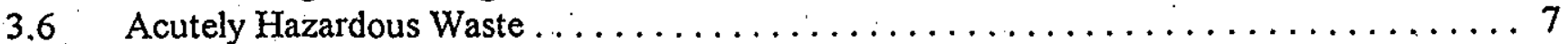

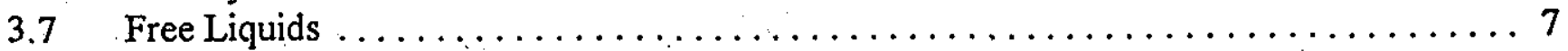

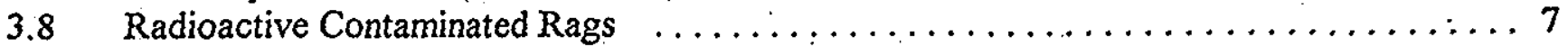

3.9 Unknown Wastes $\ldots \ldots \ldots \ldots \ldots \ldots \ldots \ldots \ldots \ldots \ldots \ldots \ldots \ldots \ldots \ldots \ldots$

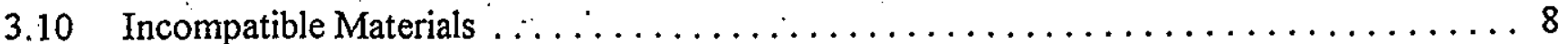

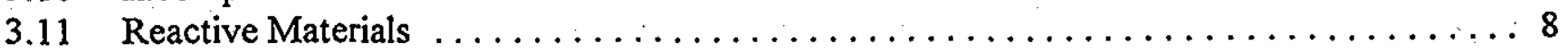

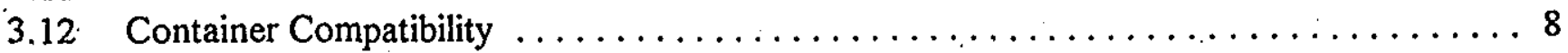

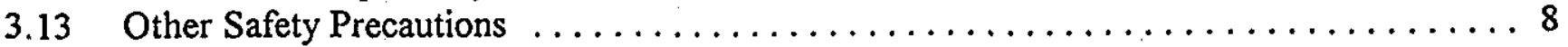

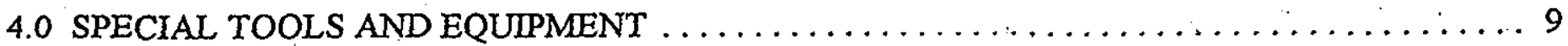

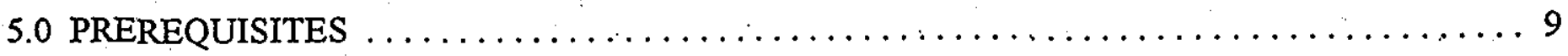

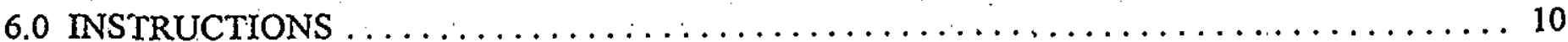

6.1 Prepare Compactible Room Waste Drums $\ldots \ldots \ldots \ldots \ldots \ldots \ldots \ldots \ldots \ldots$

6.2 Prepare Low Level Radioactive Waste Containers $\ldots \ldots \ldots \ldots \ldots \ldots \ldots \ldots \ldots \ldots$

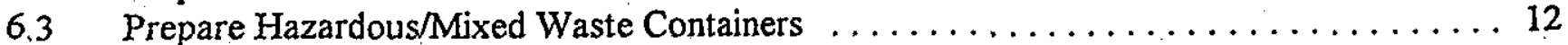

6.4 Prepare Hot Cell Waste Container (See the Appendix D.) .................. 13

6.5 Collect and Manage Compactible Room Waste ....................... 16

6.6 Collect and Manage Low-Level Radioactive Waste $\ldots \ldots \ldots \ldots \ldots \ldots \ldots \ldots \ldots$

6.7 Low Level Radioactive Waste to be Crushed or Shredded .................. 19

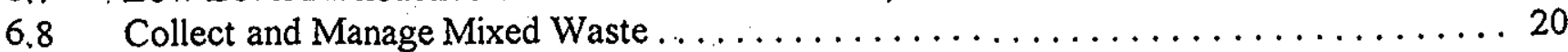

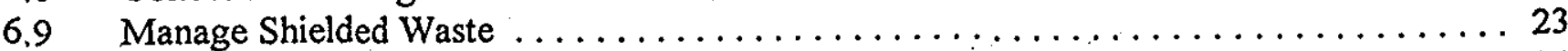

6,10 Collect and Manage Hot Cell Waste ............................. 24

6.11 Routine Changeout of Compactible Waste Drum Liners $\ldots \ldots \ldots \ldots \ldots \ldots \ldots \ldots$

6.12 Alternate Changeout of Compactible Waste Drum .................... 27

6.13 Manage Radioactively contaminated Non-Routine Waste $\ldots \ldots \ldots \ldots \ldots \ldots \ldots 28$ 


\section{WASTE MANAGEMENT LABORATORY \\ SEGREGATE AND MANAGE SOLID LABORATORY WASTES}

LO-100-151

6.14 Collect and Manage Solid Chemical Waste . . . . . . . . . . . . . . . . . . 29

6.15 Routine Cubicle Waste Load-Out . .......................... 31

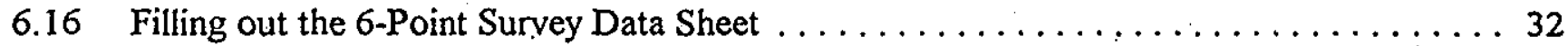

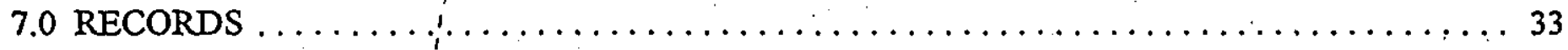

Appendix A. Example of Magnetic Compactible Waste Contents Sheet Sign $\ldots \ldots \ldots \ldots \ldots \ldots \ldots . \ldots$

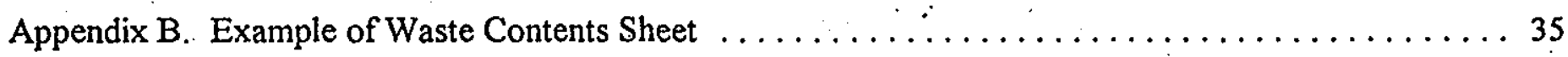

Appendix C. Example of 222-S Hazardous Waste Labels $\ldots \ldots \ldots \ldots \ldots \ldots \ldots \ldots \ldots \ldots \ldots$

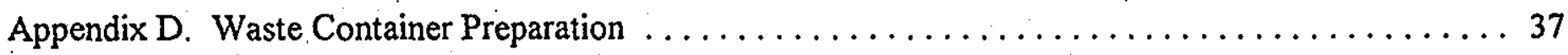

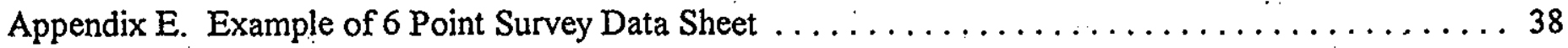


SEGREGATE AND MANAGE SOLID LABORATORY WASTES

LO-100-151

$\underline{\text { Revision Status }}$

Change

Level

E-0

E-1

E-2

$\mathrm{E}-3$

E-4

$\frac{\text { Date }}{10 / 07 / 98}$

Change

Document

LO-100-151

LO-100-151

25

22 and 24

3 and 23

$\underline{\text { Page(s) }}$

All

99-30

$99-49$

$06 / 30 / 99$

$11 / 16 / 99$

$99-140$

10
Description

Exempt non-contaminated glass and other items from packaging and labeling requirements. Change $\mathrm{mRad} / \mathrm{hr}$ to $\mathrm{mr} / \mathrm{hr}$. Format change.

Editorial only. Change step 6.11.11 to read 6.11.7 through 6.11.9.

Editorial only. Change step callouts.

Delete reference LO-100-155, add step 6.10.1, change term from smearable to removable throughout procedure.

Add procedure step caveat. 


\section{WASTE MANAGEMENT LABORATORY \\ SEGREGATE AND MANAGE SOLID LABORATORY WASTES \\ LO-100-151}

PAGE 4 of 38

\subsection{PURPOSE AND SCOPE}

This procedure establishes the guidelines for collecting and packaging of solid laboratory wastes (for example, glass, metal, plastic) low-level radioactive and radioactive hazardous (mixed) wastes within the 222-S Complex.

\subsection{REFERENCES}

LO-100-107, Cubicle Housekeeping and Waste Management

L0-161-172, Perform Complex 11A Hot Cell Operation

LO-100-166, Manage Satellite Accumulation Area, 90 Day Accumulation Areas and the Treatment, Storage, Disposal (TSD) Units

\subsection{PRECAUTIONS AND LIMITATIONS}

Work is performed under the guidance and direction of the generator's manager or designee. The user shall apply training, working knowledge and best judgement to perform the work required. Deviation in the order which steps occur is allowed with prior approval from the Manager.

Waste is collected within laboratory hoods and laboratory rooms in approved waste container, U. S. Department of Transportation shipping containers, or appropriate containment during routine or off-normal working conditions. Waste generated during maintenance or construction activities is collected and placed in U. S. Department of Transportation shipping containers.

\subsection{Solid Low Level Radioactive Waste}

\section{NOTE}

Hazardous wastes, or mixed wastes, are not disposed of or mixed with low-level radioactive or compactible wastes. Disposal of this nature will be in violation of state and or federal regulations and waste acceptance criteria.

3.1.1 Compactible waste - The approved contents for waste to be compacted are paper, dry rags, gloves, clothing, plastic wraps, and other dry, low density, compactible wastes. These wastes are managed as low-level radioactive materials. Dry, less than detectable smear media are acceptable for disposal to a compactible room waste drum. 


\section{WASTE MANAGEMENT LABORATORY \\ SEGREGATE AND MANAGE SOLID LABORATORY WASTES \\ LO-100-151}

PAGE 5 of 38

REV/CHANGE NO. E-4

Printed: November 12, $19992: 23 \mathrm{pm}$

EFFECTIVE DATE $11 / 16 / 99$

- Wastes that are prohibited in compactible room waste drums include glass, empty plastic bottles, stir bars, metal, hard plastic, rigid cardboard, hazardous waste, and radioactively contaminated articles including contaminated smear media or unidentified and uncharacterized wastes. Free standing liquids are not allowed.

3.1.2 For burial - Solid low level radioactive wastes generated at the 222-S Complex include empty (by definition in 3.2) polybottles, scintillation vials, T-9 vials, alpha and beta discs, planchettes, glass vials, and miscellaneous wastes.

3.1.3 Contaminated Smear Media - Contaminated smear media which has not come into direct contact with a listed waste sample or a listed waste, can be disposed of as a lowlevel radioactive waste. For example: A contamination smear of a hood in which the smear media (to the knowledge of the person performing the smear) does not directly contact the sample material or waste in the hood, but radioactive contamination is detected on the smear media. The smear media can be disposed of as low-level radioactive waste.

\subsection{Empty Containers}

A container (for example, poly bottles, scintillation vials, pipet tips, and so forth) is considered empty and nonhazardous when all wastes in it have been taken out that can be removed using commonly employed practices and it contains no visible sludge or free-flowing liquids.

If the container held acutely hazardous waste ("P" waste codes), toxic extremely hazardous waste (EHW waste codes WT01) or pesticides bearing the danger or warning label, the container must be rinsed at least . three times with an appropriate cleaner or solvent. The volume of the cleaner or solvent used for each rinsing must be ten percent or more of the container's capacity or of sufficient quantity to thoroughly decontaminate the container. Any rinsate or residue which results from the cleaning of containers must be properly managed as a hazardous waste.

Hood Waste-(Contaminated Glass Containers) may be taken to $2 \mathrm{~B}$ hood 16 (North side), to be crushed. The container must be empty and dry.

\subsection{Solid Mixed Waste}

3.3.1 Solid mixed waste derived from listed tank samples - Any solid waste which comes into contact with, or is derived from the analysis or management of tank farms sample or waste is to be assigned the listed waste codes FOO1, FOO2, FOO3, FOO4, and FOO5.

Waste known through process knowledge, not to be derived from Tank Farm samples or waste, do not carry the above listed waste codes unless otherwise directed by Hazardous Materials Control (HMC) manager and Environmental Compliance Officer (ECO). 


\section{WASTE MANAGEMENT LABORATORY \\ SEGREGATE AND MANAGE SOLID LABORATORY WASTES}

LO-100-151

PAGE 6 of 38

Solid mixed waste derived from other listed waste sources - Any solid waste which comes into contact with or is derived from the analysis or management of a sample or waste which carries a listed waste code is to be assigned the listed waste code of that sample or waste (examples would be $U$ or $P$ coded wastes).

Example: If a listed waste sample is brought into a hood for analysis, any items which come into contact with the sample (Examples of Mixed Waste in hoods: Plastic bags, gloves, dental rolls, stir bars, tissues, paper towels, metal scoops, dried pens and dried sharpies) and are determined to be waste shall be handled as mixed waste. Containers or vials can be disposed of as nonhazardous low-level radioactive waste, if they are empty by definition.

\subsection{Hot Cell and Shielded Waste}

Waste is generated from analytical procedures which are performed on undiluted Single Shell Tank or - Double Shell Tank samples. This waste is typically generated, (but not limited to) hoods performing the following analyses: TGA/DSC, TIC/TOC, percent water, acid digest, fusion, water digest, and includes tank waste generated within the hot cells.

Containers with a wall thickness greater than a metal lard can, are considered a shielded container and the waste in them must be managed as a shielded waste in accordance with Section 6.9.

\subsection{Lead Management/Usage}

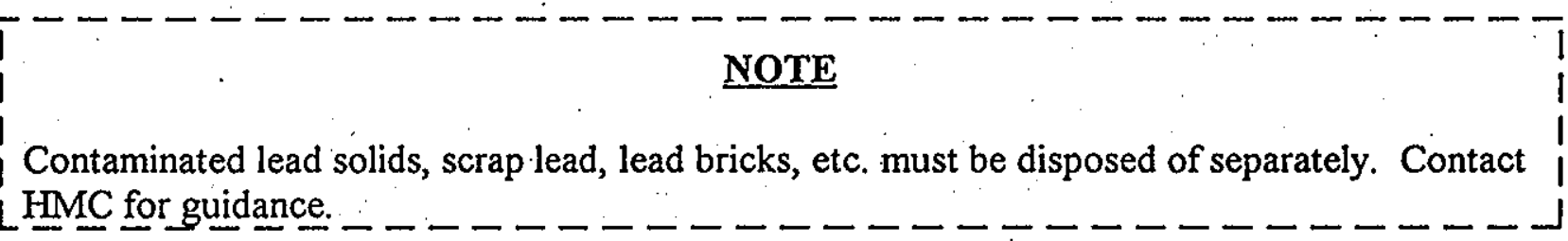

Lead can be used for shielding of non-hazardous and hazardous radioactive waste packages providing other means of shielding have been used to try and reduce the dose rate. When these other means fail, lead may be used provided the package is clearly marked with the word "Lead used as shielding" and the container is disposed of as shielded mixed waste. Lead waste (for example, lead tape, lead lined gloves, lead contacts on light bulbs) must be noted as lead waste on the inventory sheet. Lead is only to be disposed of as hazardous or mixed waste. Lead is strictly forbidden in low level radioactive waste drums. Improper disposal of lead can result in drum having to be sorted and repackaged. Improper disposal of lead is a violation of state and federal regulations. 


\section{WASTE MANAGEMENT LABORATORY \\ SEGREGATE AND MANAGE SOLID LABORATORY WASTES}

LO-100-151

PAGE 7 of 38

REV/CHANGE NO. E-4

Printed: November 12, 1999 2:23pm

EFFECTIVE DATE 11/16/99

\subsection{Acutely Hazardous Waste}

An Acutely Hazardous Waste is any discarded pure chemical product(s) (listed in WAC-173-303-9903) that are identified with a dangerous waste number beginning with "P" (for example, copper cyanide PO29). Additionally any of the following waste codes are acutely Hazardous FO20, FO21, FO22, FO23, FO26, or FO27.

\subsection{Free Liquids}

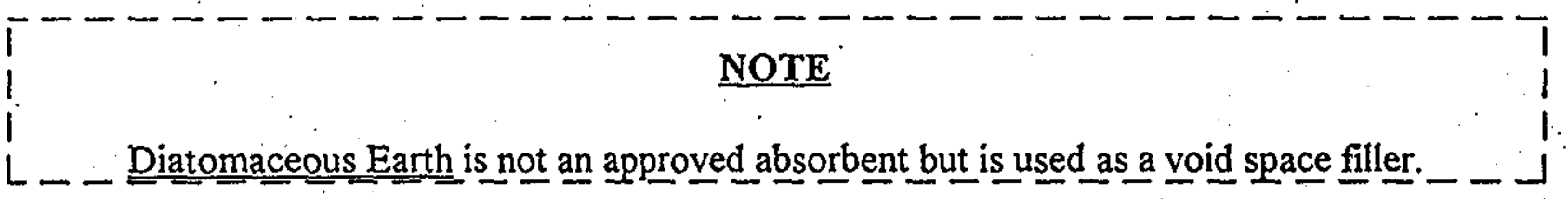

Free liquids are not allowed in Low-Level Radioactive waste containers. Any bottles or vials which have held free liquids are required to have an approved absorbent placed in them if they are not dry. Absorbants approved for use at the laboratories include Imbiber beads for organics, and Radsorb for aqueous. If an approved absorbent is not available contact the Hazardous Materials Control group (HMC) for guidance.

\subsection{Radioactive Contaminated Rags}

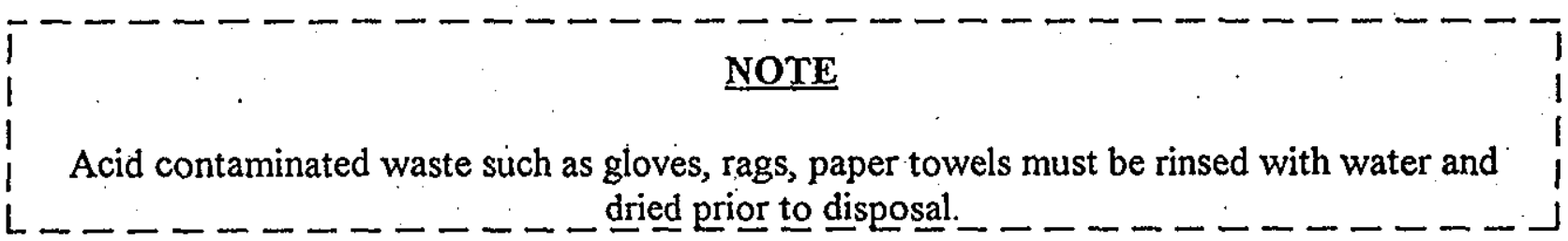

3.8.1 Radioactive Contaminated Acid/Caustic Rags may be rendered as nonhazardous by rinsing the rags in water and drying the rags. The rinsate must be managed as mixed waste if it exhibits the characteristic of corrosivity (for example, $2.0<\mathrm{Ph}>12.5$ )

\subsubsection{Radioactive Oily Rags}

Non hazardous radioactive oily rags must be moved outside by the end of each day to the low-level radioactive non-regulated oily rag drum by HMC.

Hazardous radioactive oily rags must be moved outside by the end of each day to the mixed waste oily rag drum by HMC. 
HNF-5443, rev. 0

\section{WASTE MANAGEMENT LABORATORY \\ SEGREGATE AND MANAGE SOLID LABORATORY WASTES \\ LO-100-151}

PAGE. 8 of 38

REV/CHANGE NO. E-4

- Printed: November 12,1999 2:23pm

EFFECTIVE DATE 11/16/99

\subsection{Unknown Wastes}

Unknown or abandoned wastes or containers of waste are to be immediately reported to immediate manager, facility manager, ECO, and/or HMC manager. All unknown wastes will be labeled with the date of sampling and the words "Waste Pending Analysis" and stored in a 90-Day Area until analytical data is complete enough to designate waste.

\subsection{Incompatible Materials}

Do not place incompatible materials into a single container. Examples of these include oxidizing acids (e. g. nitric acid and sulfuric acid) and rags or paper, acid waste, and cyanide or sulfides, oxidizers and reductants, and peroxides and paper. If a waste is believed to be incompatible with other wastes being handled, consult the MSDS for guidance on compatibility of the waste.

\subsection{Reactive Materials}

Do not place reactive materials into containers. These include alkali metals, explosives, pyrophorics (uranium metal), and chelating compounds. If a waste is believed to be reactive with other wastes being handled, consult the MSDS for guidance on compatibility of the waste.

\subsection{Container Compatibility}

To help prevent chemical reactions and container deterioration, waste collection containers must be compatible with the waste being placed into them. Containers must be made of or lined with materials that will not react with, and are otherwise compatible with, the waste to be stored, so that the ability of the container to contain waste is not impaired. For example, Hydrofluoric Acid will etch glass and should be collected in polyethylene containers. Consult WHC-SD-CP-LB-028, Laboratory Reagents, in determining the type of container to be used for collecting wastes.

\subsection{Other Safety Precautions}

Wear leather gloves over surgical gloves when handling sharp objects.

Use proper lifting techniques when lifting heavy or awkward loads.

A cart should be used for transporting container's of waste which are heavy (lead lined) or pose an ALARA concern. 
WASTE MANAGEMENT LABORATORY

SEGREGATE AND MANAGE SOLID LABORATORY WASTES

LO-100-151.

PAGE 9 of 38

REV/CHANGE NO. E-4

Printed: November 12, 1999 2:23pm

EFFECTIVE DATE 11/16/99

\subsection{SPECIAL TOOLS AND EQUIPMENT}

Approved absorbent (e. g., radsorb, imbiber beads, universal poly propylene)

Approved void spacę filler [e. g., Diatomaceous earth (Clean Up IV), pyrofoam]

Approved containers

Magnetic Compactible Waste Contents Sign (Appendix A)

Polyethylene liners

Rubber and Lead Shielding

Survey equipment

Tape

Waste Contents Sheet (see Appendix B)

222-S Hazardous Waste label (see Appendix C)

6 Point Survey Data Contents Sheet (See Appendix E)

\subsection{PREREQUISITES}

Not Applicable. 
HNF-5443, rev. 0

\section{WASTE MANAGEMENT LABORATORY \\ SEGREGATE AND MANAGE SOLID LABORATORY WASTES \\ LO-100-151}

\subsection{INSTRUCTIONS}

\section{NOTES}

Sections, or steps within sections, of this procedure may be performed out of sequence, as required.

Labels may be obtained from HMC or stockroom.

\subsection{Prepare Compactible Room Waste Drums}
6.1.1 OBTAIN a drum.

6.1.2 REMOVE drum lid and accessories.

6.1.3 PLACE drum into laboratory room or area for collection of waste.

6.1.4 MARK drum with three radioactive waste stickers $120^{\circ}$ apart on the side of the drum.

6.1.5 ATTACH a magnetic Compactible Waste Contents Sheet sign to the drum (See Appendix A).

6.1.6 OBTAIN two (4 mil minimum) polyethylene yellow liners.

6.1.7 INSPECT polyethylene liners for defects (punctures and tears).

6.1.8 DISCARD and

REPLACE any faulty liners.

6.1.9 INSERT polyethylene liner into drum.

6.1.10 FOLD top of liner over rim of drum.

6.1.11 REPEAT steps 6.1.9 and 6.1.10 to install second liner.

I

A swing lid is not required for compactible room waste drums. On a case by case basis a swing lid may be Lused.

6.1.12 PLACE swing lid on drum if one is to be used. 


\section{WASTE MANAGEMENT LABORATORY \\ SEGREGATE AND MANAGE SOLID LABORATORY WASTES \\ LO-100-151}

PAGE 11 of 38

REV/CHANGE NO. E-4

Printed: November 12, 1999 2:23pm

EFFECTIVE DATE 11/16/99

\subsection{Prepare Low Level Radioactive Waste Containers}

6.2.1 OBTAIN approved container and appropriately sized poly liner for collection of low-level radioactivé (LLR) waste.

\subsubsection{MARK or}

LABEL side and top of the container "Low:Level Radioactive Waste", "Low-Level Waste", "Low-Level" or "LLR".

a. IF waste to be collected is known to contain PCBs

PLACE a yellow and black "Known PCB" label on container noting the project location.

- This label can be obtained from HMC or the stockroom.

b. IF waste to be collected is suspected to contain PCBs

PLACE a white and red "Suspect PCB" label on the container noting the project location.

- This label can be obtained from HMC or the stockroom.

6.2.3 WRITE room number on side of waste container.

6.2.4 PLACE poly liner inside container.

6.2.5 FOLD top of liner over lip of container, and

PRESS liner toward sides and bottom.

6.2.6 PLACE prepared container into area for waste collection and ENSURE Low-Level Radioactive marking is visible.

6.2.7 OBTAIN a Waste Contents. Sheet and fill out while collecting low-level radioactive waste. (Appendix B)

a. CHECK appropriate square for type of waste being collected

b. RECORD room number

c. RECORD hood number (if applicable)

d. ITEMIZE miscellaneous items placed in the waste container. 
HNF-5443, rev. 0

WASTE MANAGEMENT LABORATORY

SEGREGATE AND MANAGE SOLID LABORATORY WASTES

LO-100-151

PAGE 12 of 38

REV/CHANGE NO. E-4

Printed: November 12, $19992: 23 \mathrm{pm}$

EFFECTIVE DATE 11/16/99

\subsection{Prepare Hazardous/Mixed Waste Containers}

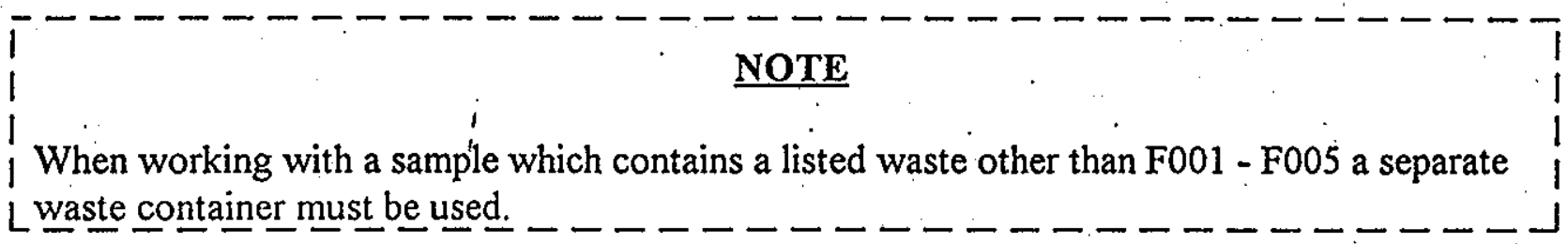

6.3.1 OBTAIN approved container and appropriately sized poly liner.

6.3.2 PLACE poly liner inside container.

6.3.3 FOLD top of liner over lip of container, and

PRESS liner towards sides and bottom.

6.3.4 OBTAIN two blank hazardous waste labels. (Appendix C)

a. AFFIX one to container side and one to the lid of the container.

b. IF a Hazardous Waste label is not available, or used

ENSURE the words "Hazardous Waste" are placed visibly on the container.

1. ENSURE that the major risk (e. g. toxic, flammable, corrosive) is placed visibly on the container.

6.3.5 IF waste to be collected is known to contain PCBs

PLACE a yellow and black "Known PCB" label on the container noting the project location.

- This label can be obtained from HMC or the stockroom.

6.3.6 IF waste to be collected is suspected to contain PCBs

PLACE a white and red "Suspect PCB" label on the container noting the project location.

- This label can be obtained from HMC or the stockroom.

6.3.7 RECORD room number and hood number on hazardous waste label or container.

a. On shielded waste container, write tank number or area from which waste was generated (for example, 101-SC, T-111).

- When more than two tanks are present use the 219-S as the tank number. 
HNF-5443, rev. 0

\section{WASTE MANAGEMENT LABORATORY \\ SEGREGATE AND MANAGE SOLID LABORATORY WASTES \\ LO-100-151}

6.3.8 PLACE labeled container into another container for stability and/or shielding purposes, if necessary.

6.3.9 ENSURE either the inner container label is visible, or the outer container has an identical label and is visible.

\section{NOTE}

Waste container lid is securely in place at all times when work is not being performed.

6.3.10 PLACE prepared container into area for waste collection.

a. ENSURE the hazardous waste label is visible.

6.3.11 OBTAIN a Waste Contents Sheet and fill out while collecting mixed waste.

a. CHECK appropriate square for type of waste being collected.

b. RECORD room number.

c. RECORD hood number (if applicable)

d. ITEMIZE miscellaneous items placed in the waste container.

\subsection{Prepare Hot Cell Waste Container (See the Appendix D.)}

\section{NOTE}

When working with a sample which contains a listed waste other than F001 - F005 a separate waste container must be used.

The following description is intended as a guide only. Individual users will develop their own techniques for waste container preparation.

\subsubsection{PREPARE and}

LABEL inner waste container.

a. USE an approved inner container. 
HNF-5443, rev. 0

\section{WASTE MANAGEMENT LABORATORY \\ SEGREGATE AND MANAGE SOLID LABORATORY WASTES}

LO-100-151

b. TIE knots in the end of any suitable material (for example, Tygon ${ }^{1}$ tubing) to form a bail.

c. TAPE the ends of the bail to opposite sides of the container leaving room for the lid.

d. TAPE a 2-in. piece of Tygon to the lid to provide a handle to grasp with the manipulator.

e. WRITE on or

LABEL the container with the words "Hazardous Waste."

f. WRITE on or

LABEL the container with the major risk associated with the waste (e. g. Toxic, flammable, corrosive).

g. WRITE tank number or area from which waste was generated (e. g. 101-SC, T-110, K-Basin).

h. IF waste to be collected is known to contain PCBs

PLACE a yellow and black "Known PCB" label on the container noting the project location.

- This label can be obtained from HMC or the stockroom.

i. IF waste to be collected is suspected to contain PCBs

PLACE a white and red "Suspect PCB" label on the container noting the project location.

- This label can be obtained from HMC or the stockroom.

\subsubsection{PREPARE and}

LABEL outer waste container.

a. USE an approved outer container.

b. TIE knots in the end of any suitable material (e.g., Tygon tubing) to form a bail.

c. TAPE the ends of the bail to opposite sides of the container leaving room for the lid. 
HNF-5443, rev. 0

\section{WASTE MANAGEMENT LABORATORY \\ SEGREGATE AND MANAGE SOLID LABORATORY WASTES}

LO-100-151

\section{NOTE}

L__ _ _. For extra shielding, additional rubber matting or lead shielding may be used.

d. LINE the can with rubber matting and/or other suitable material as necessary.

e. PLACE a plastic bag in the center of the waste container and fold bag over the outside of the container.

f. TAPE a 2-in. piece of Tygon to the lid to provide a handle to grasp with the manipulator.

g. ATTACH shielding material to the inside of the container lid.

6.4.3 OBTAIN two blank hazardous waste labels. (Appendix C)

a. AFFIX one to container side and one to the lid of the container.

b. IF a Hazardous Waste label is not available, or used

ENSURE the words "Hazardous Waste" are placed visibly on the container.

1. ENSURE the major risk (e. g. toxic, flammable, corrosive) is placed visibly on the container.

6.4.4 WRITE the hot cell location where the waste was generated on the container.

a. IF waste to be collected is from Tank Farm samples

ATTACH an "F-Listed" waste label to the container.

- hot cell waste containers must be labeled with the tank number or area from which the waste was generated (for example, 101-SC, T-111 K-Basin).

6.4.5. IF waste to be collected is waste known to contain PCBs

PLACE a yellow and black "Known PCB" label on the container noting the project location.

- This label can be obtained from HMC or the stockroom.

6.4.6 IF waste to be collected is waste suspected to contain PCBs

PLACE a white and red "Suspect PCB" label on the container noting the project location.

- This label can be obtained from HMC or the stockroom. 
HNF-5443, rev. 0

\section{WASTE MANAGEMENT LABORATORY \\ SEGREGATE AND MANAGE SOLID LABORATORY WASTES \\ LO-100-151}

6.4.7 PLACE prepared container into area for waste collection ensuring that the hazardous waste label is visible.

6.4.8 OBTAIN a Waste Contents Sheet and fill out while collecting hot cell radioactive waste.
a. CHECK appropriate square for type of waste being collected
b. RECORD room number
c. RECORD hood number (if applicable)
d. ITEMIZE miscellaneous items placed in the waste container.

\subsection{Collect and Manage Compactible Room Waste}

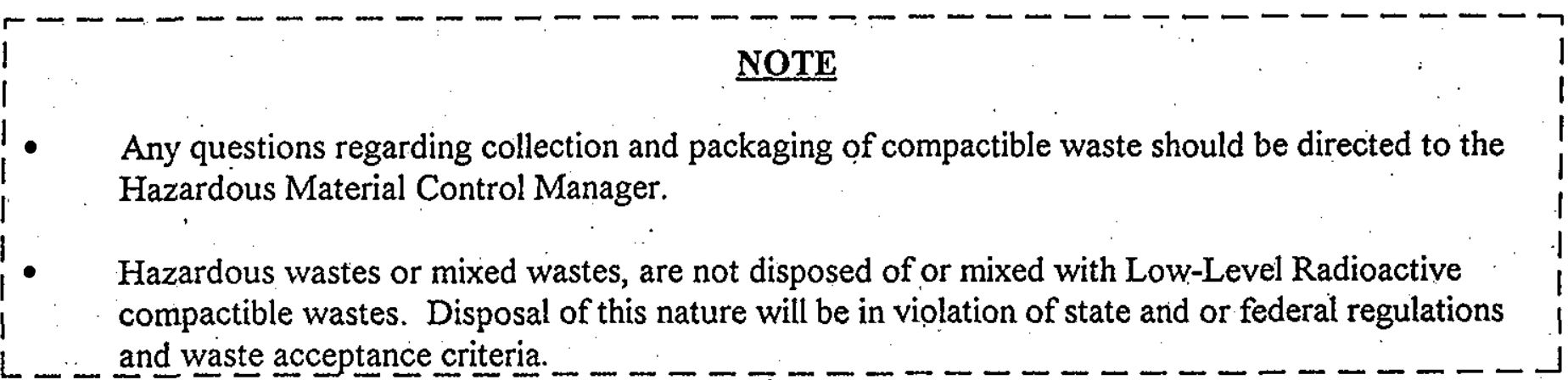

6.5.1 SEGREGATE low-level radioactive compactible waste from other waste types, as it is generated, in predesignated drums located in the laboratory rooms.

6.5.2 CONTINUE filling drum until drum is visibly full.

6.5.3 CHANGE out bagged drum waste following Sections 6.11 or 6.12. 
HNF-5443, rev. 0

\section{WASTE MANAGEMENT LABORATORY \\ SEGREGATE AND MANAGE SOLID LABORATORY WASTES \\ LO-100-151}

REV/CHANGE NO. E-4

Printed: November 12, $1999 \quad 2: 23 \mathrm{pm}$

PAGE 17 of 38

EFFECTIVE DATE 11/16/99

\subsection{Collect and Manage Low-Level Radioactive Waste}

When disposing of equipment, the property number, serial numbers and any other ID numbers (when
present) needs to be recorded on property disposal paperwork. HMC can provide assistance with
Lproperty disposal paperwork issues.

\section{WARNING}

Sharp objects and sharp edges must be padded and taped to prevent injury.

6.6.1 CONTACT HIMC for guidance prior to packing waste items too large to fit into a standard collection container.

6.6.2 IF the container has a Standards Laboratory bar code,

CONTACT the Standards Laboratory and report the bar code number (located directly below the bar code) as an empty container.

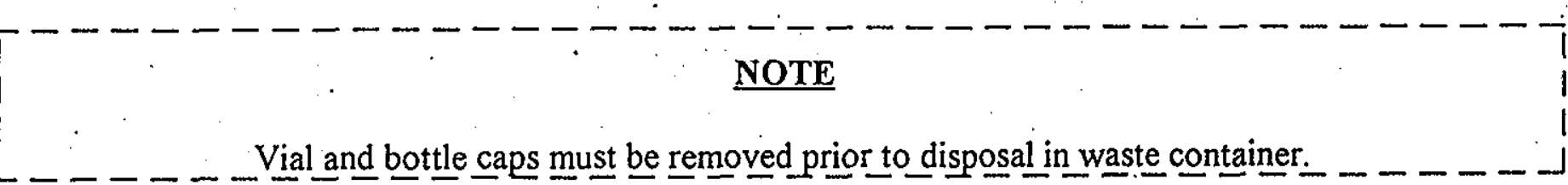

6.6.3 PLACE only empty; and nonhazardous items into the waste container.

6.6.4 ADD approved absorbent to containers which may have residual liquids present as follows:

a. $10 \mathrm{ml}$ minimum of imbiber beads for residual organic liquids.

b. $\quad 2 \mathrm{ml}$ minimum of radsorb for residual aqueous liquids.

6.6.5 FILL out Waste Contents Sheet when collecting waste.

a. ITEMIZE miscellaneous items placed in the waste container. 


\section{WASTE MANAGEMENT LABORATORY \\ SEGREGATE AND MANAGE SOLID LABORATORY WASTES \\ LO-100-151}

6.6.6 IF container is full or ready for removal from hood, HORSETAIL and

TAPE liner.

a. TAPE or

SECURE lid onto container. NOTE

L

6.6.7 NOTIFY HPT to take contact readings of waste.

a. IF readings are greater than $100 \mathrm{mr} / \mathrm{hr}$ at contact, SHIELD container to less than $100 \mathrm{mr} / \mathrm{hr}$ on contact.

- IF lead shielding is used container must be managed as mixed waste. (Go to Section 6.9)

6.6.8 DOUBLE BAG container, HORSETAIL, and

TAPE bags.

- Outer bag must be yellow.

6.6.9 ENSURE outer bag has no removable contamination.

$$
1
$$

Percentages of waste includes the container, items inside the container, void space filler, absorbent, liner, Ltape, and bags. The percentages are based on volume.

6.6.10 COMPLETE Waste Contents Sheet as follows:
a. RECORD size of container
b. RECORD percentages of waste
c. RECORD room number.
d. RECORD hood number. 
HNF-5443, rev. 0

\section{WASTE MANAGEMENT LABORATORY \\ SEGREGATE AND MANAGE SOLID LABORATORY WASTES \\ LO-100-151}

e. RECORD the date

f. PRINT your name.

6.6.11 ATTACH Waste Contents Sheet to outside bag.

6.6.12 ENSURE container is labeled and dose rate established by HPT is written on container prior to transporting.

6.6.13 TRANSPORT the container to Room 4E Low-Level Radioactive storage area.

a. IF waste is suspect or known PCB waste,

HAVE HMC personnel present to receive waste.

\subsection{Low Level Radioactive Waste to be Crushed or Shredded}

\section{NOTE}

Free standing liquid is not allowed in shredder or hot crusher.

PCB waste is not allowed in shredder or hot crusher.

When collecting vials/bottles to be crushed or shredded void space filler is not required. However, the container must be empty, non-hazardous, and dry.

The following are examples of acceptable materials:

Shredder-empty nonhazardous, nonremovable, Plastic and glass bottles, cardboard, small pieces of wood. Materials generated inside a hood that have not contained radioactive material and have no removable contamination.

Glass Crusher-contaminated empty nonhazardous glass and plastic vials, bottles, reading $<100$ $\mathrm{L} \ldots \mathrm{mr} / \mathrm{hr}$ at contact.

6.7.1 CONTACT HMC for guidanice on what materials are acceptable for shredding or crushing.

6.7.2 IDENTIFY items to be shredded or crushed.

6.7.3 IF items(s) are non-contaminated such as empty reagent bottles, or other items collected from rooms or benchtops, LABEL as "Non-Rad waste for shredder" and SKIP to step 6.7.9. 


\section{WASTE MANAGEMENT LABORATORY \\ SEGREGATE AND MANAGE SOLID LABORATORY WASTES \\ LO-100-151}

6.7.4 NOTIFY HPT to take contact readings of waste to be shredded or crushed.

- Containers must be reading $<100 \mathrm{mr} / \mathrm{hr}$ at contact.

6.7.5 BAG container, HORSETAIL, and

TAPE bag for any items being taken to the shredder or crusher.

- Outer bag must be yellow.

6.7.6 ENSURE outer bag has no removable contamination before removing from collection area.

6.7.7 LABEL outer bag or container as "shredder" or "Glass Crusher" waste.

- This can be done with a marking pen, a piece of tape with the appropriate labeling, etc.

6.7.8 ENSURE container is labeled as "shredder" or "glass crusher" and dose rate established by HPT and written on container, prior to storing in staging area.

6.7.9 TRANSPORT container to designated staging area for either the hot crusher or the shredder.

\subsection{Collect and Manage Mixed Waste}

\section{WARNING}

All corners and sharp edges must be padded and taped to prevent injury.

6.8.1 CONTACT HMC for guidance prior to packaging when working with waste items too large to fit into a standard collection container,

6.8.2 IF waste to be collected is shielded waste, PROCEED to Section 6.9.

6.8.3 IF waste to be collected is Hot Cell Waste, PROCEED to Section 6.10. 
HNF-5443, rev. 0

\section{WASTE MANAGEMENT LABORATORY \\ SEGREGATE AND MANAGE SOLID LABORATORY WASTES}

LO-100-151

PAGE 21 of 38

6.8.4 CONTACT HMC for assistance in disposal of the following waste types.

- Waste containers shielded with lead or rubber.

- All waste generated in hot cells.

- Items too large to fit in a standard container (ice cream cartons or lard cans).

- PCB wasté.

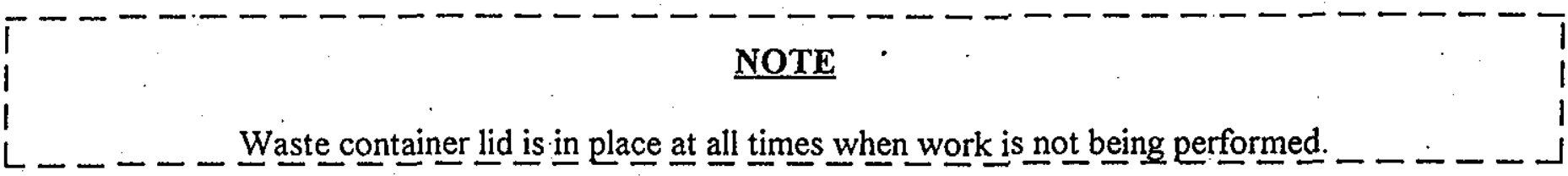

6.8.5 PLACE only mixed waste into container.

a. IF packaging containers which may have residual liquids present, ADD approved absorbent to container as follows:

1. $10 \mathrm{ml}$ minimum of imbiber beads for residual organic liquids.

2. $2 \mathrm{ml}$ minimum of radsorb for residual aqueous liquids.

6.8.6 FILL OUT Waste Contents Sheet when collecting waste.

a. ITEMIZE miscellaneous items placed in the waste container.

6.8.7 PERFORM the following when container has been filled to within $25 \mathrm{~mm}$ (1 in.) of the top

a. HORSETAIL and tape liner

b. TAPE lid onto container

c. NOTIFY HPT to take contact reading of waste.

1. IF contact reading is greater than $100 \mathrm{mr} / \mathrm{hr}$ GO to Section 6.9 .

6.8.8 DOUBLE BAG container, HORSETAIL, and

TAPE bags.

- Outer bag must be yellow. 
HNF-5443, rev. 0

\section{WASTE MANAGEMENT LABORATORY \\ SEGREGATE AND MANAGE SOLID LABORATORY WASTES \\ LO-100-151}

PAGE 22 of 38

REV/CHANGE NO. E-4

Printed: November 12, 1999 2:23pm

EFFECTIVE DATE 11/16/99

6.8.9 ENSURE outer bag has no removable contamination before removing from collection area.

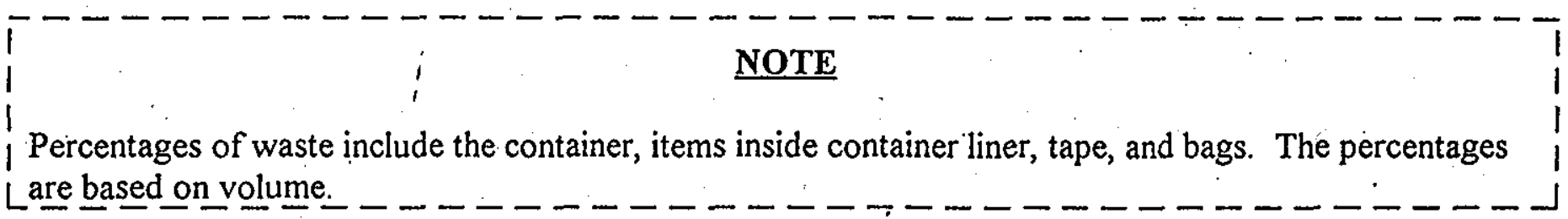

6.8.10 COMPLETE Waste Contents Sheet as follows:
a. RECORD size of container
b. RECORD percentages of waste
c. RECORD room number
d. RECORD hood number
e. RECORD the date
f. PRINT your name.

6.8.11. ATTACH Waste Contents Sheet to outside of bag.

6.8.12 ENSURE the container is labeled and dose rate established by HPT is written on container(s) or label(s) prior to transferring to a 90-day accumulation area.

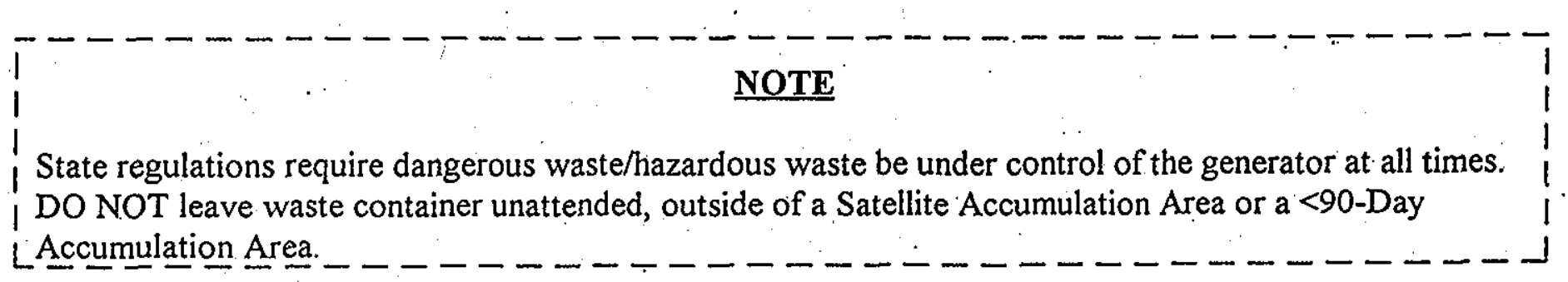

6.8.13 TRANSFER waste to room 4E 90-Day Accumulation Area.

6.8.14 LOG waste into room 4E 90 Day Accumulation Area per LO-100-166.

- IF waste is suspect or known PCB waste, HMC personnel must be present to receive waste. 


\section{WASTE MANAGEMENT LABORATORY \\ SEGREGATE AND MANAGE SOLID LABORATORY WASTES \\ LO-100-151}

\subsection{Manage Shielded Waste}

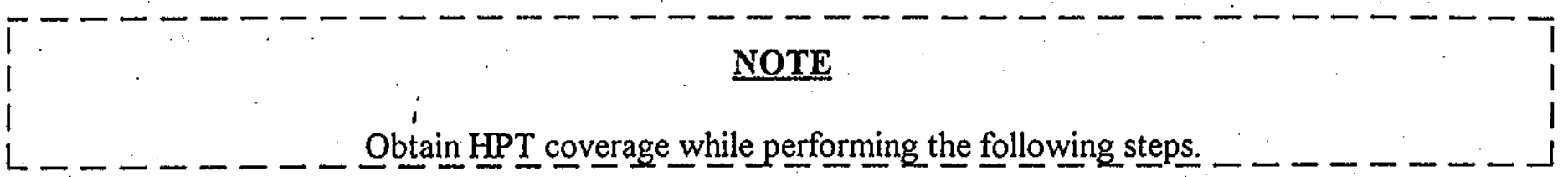

6.9.1 SHIELD container to less than $100 \mathrm{mr} / \mathrm{hr}$ using rubber and/or lead.

- IF lead shielding is used

MARK container with the words "Lead used as shielding."

6.9.2 DOUBLE BAG container,

HORSETAIL, and

TAPE bags.

- Outer bag must be yellow.

6.9.3 ENSURE outer bag has no removable contamination prior to moving from collection area.

6.9.4 FILL OUT the appropriate sections of the 6-Point Survey Data Sheet (Appendix E) (See Section 6.1.16 for complete instructions on filling out the 6-Point Survey Data Sheet.)

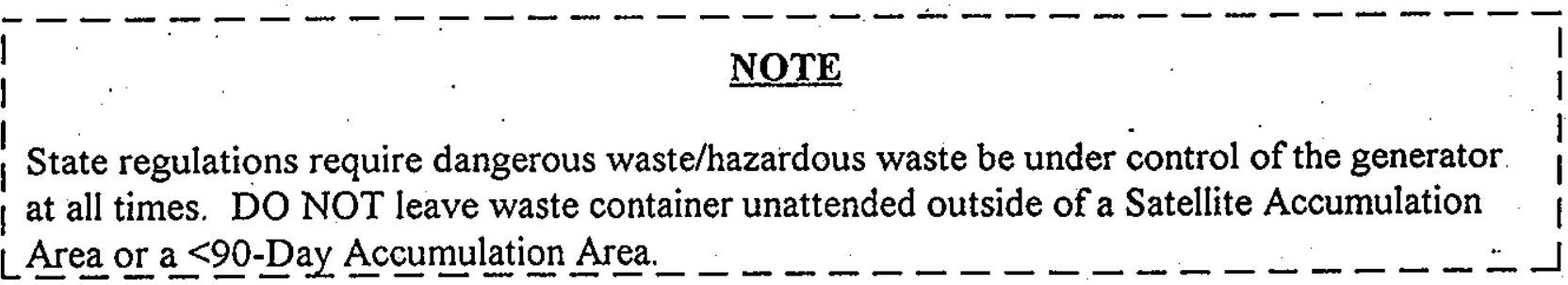

6.9.5 REQUEST an HPT to perform a 6-Point Survey and fill out the appropriate sections of the 6-Point Survey Data Sheet.

\section{NOTE}

1. HMC personnel are responsible for logging all mixed waste containers into the 90 day accumulation Larea.

6.9.6 TRANSPORT container to the 90-Day Accumulation Area as coordinated with the HMC.

a. PROVIDE HMC with the completed 6-Point Survey Data Sheet for the container. 
WASTE MANAGEMENT LABORATORY

SEGREGATE AND MANAGE SOLID LABORATORY WASTES

LO-100-151

PAGE 24 of 38

\subsection{Collect and Manage Hot Cell Waste}

6.10.1 CONTACT Shift Operations Manager (SOM) and

REQUEST authorization to discharge to the 219-S tank system.

6.10.2 Sample and Equipment Disposal

a. REQUEST assistance from the Hazardous Material Control group (HMC) for disposal of liquid organic or other listed waste (for example pure chemical products).

\section{CAUTION}

Excess water from cubicle drains may cause overfilling of 222-S waste tanks.

b. POUR samples or dilutions into the cubicle drains while water is running for disposal.

1. TURN water OFF at completion of task.

c. RINSE vials and jars a minimum of three times with water.

1. : AIR DRY vials

d. SET vials aside for disposal.

e. RINSE paper and fabric items well.

1. SQUEEZE DRY three times

2. ALLOW to dry completely.

f. RINSE other plastic items, glassware, and equipment well.

1. AlLOW to dry

2. CONSOLIDATE as required.

g. COLLECT all glass items.

h. BREAK the glass using a heavy object. 
HNF-5443, rev. 0

\section{WASTE MANAGEMENT LABORATORY \\ SEGREGATE AND MANAGE SOLID LABORATORY WASTES}

LO-100-151

PAGE 25 of 38

REV/CHANGE NO. E-4

Printed: November 12, 1999 2:23pm

EFFECTIVE DATE 11/16/99

\section{NOTE}

L _ _ Waste container lid is securely in place at all times when work is not being performed.

i. FILL OUT a Waste Contents Sheet as items are placed in the container. Include shielding materials.

1. ITEMIZE miscellaneous items place in the waste container.

j. CONSOLIDATE miscellaneous glass, plastic, paper, fabric, and metal materials as much as possible.

k. PLACE disposable items into the inner can.

- No free liquids are allowed in the container.

1. USE two pound (quart) lard cans for highly radioactive waste. Use five pound lard cans for lower level waste.

1. CONSOLIDATE plastic in a can for future melting.

m. WHEN the container is full,

PLACE the lid evenly on the can and remove from hot cell per Section 6.15.

\subsection{Routine Changeout of Compactible Waste Drum Liners}

6.11.1 CHECK each compactible waste drum daily for fullness.

6.11.2 OBTAIN a HEPA filtered shop vacuum.

a. IF HEPA filtered shop vacuum is not available

CHANGEOUT drum in accordance with Section 6.12.

6.11.3 CHECK the following on the vacuum.

a. ENSURE the seal between the HEPA filter and the vacuum is not broken.

a. IF the seal is broken

CONTACT building operations and do not use vacuum.

b. VERIFY DOP filter test date has not expired. 


\section{WASTE MANAGEMENT LABORATORY \\ SEGREGATE AND MANAGE SOLID LABORATORY WASTES \\ LO-100-151}

6.11.4 REMOVE lid from drum if one is used.

6.11.5 TURN vacuum $O N$ and

REMOVE tape from end of hose.

6.11.6 PULL excess inner liner up and

WRAP around the end of the vacuum hose.

6.1.1.7 CONTINUE until excess air is removed from the liner.

6.11.8 REMOVE hose from liner.

6.11.9 HORSETAIL and

TAPE liner.

6.11.10 PULL excess outer liner up and

WRAP around the end of the vacuum hose.

6.11.11 REPEAT steps 6.11 .7 through 6.11 .9 for outer liner.

6.11.12 TAPE end of hose.

6.11.13 TURN vacuum OFF.

6.11.14 REMOVE double-contained waste.

6.11.15 CHECK outside of bag for tears.

a. IF liners are torn, PLACE into another liner, HORSETAU, and

TAPE.

6.11.16 INSPECT contents of bag.

a. ESTIMATE the total volume (container size) in liters (gallons), and volume percent of paper, rubber, plastic, and cloth.

6.11.17 RECORD room number, date, name, and volume percent of materials on Waste Contents Sheet.

6.11.18 WEIGH bag. 
HNF-5443, rev. 0

WASTE MANAGEMENT LABORATORY

SEGREGATE AND MANAGE SOLID LABORATORY WASTES

LO-100-151

PAGE 27 of 38

REV/CHANGE NO. E-4

Printed: November 12, 1999 2:23pm

EFFECTIVE DATE 11/16/99

6.11.19 RECORD total weight in kg on Waste Contents Sheet.

6.11.20 ATTACH. Waste Contents Sheet to bag.

6.11.21 HAVE HPT dose rate, survey and label bag prior to transferring to designated staging area.

6.11.22 IF contamination is found:

a. DECONTAMINATE as necessary.

b. NOTIFY immediate manager.

c. SEGREGATE contaminated waste per section 6.13 .

\section{NOTE}

Use the following steps if a vacuum is not available for use.

\subsection{Alternate Changeout of Compactible Waste Drum}

6.12.1 REMOVE lid from drum, if one is being used.

6.12.2 HORSETAIL and

TAPE inner liner and then outer liner.

6.12.3 REMOVE double-contained waste.

a. CHECK outside of bag for tears.

b. IF liners are torn,

PLACE into another liner,

HORSETAIL, and

TAPE.

6.12.4 INSPECT contents of bag.

a. ESTIMATE the total volume (container size) in liters (gallons), and volume percent of paper, rubber, plastic, and cloth.

6.12.5 RECORD room number, date, name, and volume percent of the materials on Waste Contents Sheet. 


\section{WASTE MANAGEMENT LABORATORY \\ SEGREGATE AND MANAGE SOLID LABORATORY WASTES \\ LO-100-151}

\subsubsection{WEIGH bag.}

6.12.7 RECORD total weight in $\mathrm{kg}$ on Waste Contents Sheet.

6.12.8 ATTACH Waste Contents Sheet to bag.

6.12.9 HAVE HPT dose rate, survey, and label bag prior to transferring to designated staging area.

6.12.10. IF contamination if found:
a. DECONTAMINATE as necessary.
b. NOTIFY immediate manager.
c. SEGREGATE contaminated waste per section 6.13.

\subsection{Manage Radioactively contaminated Non-Routine Waste}

6.13.1 SEGREGATE any radiologically contaminated waste from the waste container.

6.13.2 PLACE contaminated waste into a separate bag or container.

\subsubsection{DOUBLE BAG and}

TAPE bag or waste container.

6.13.4 IF waste is known to have been derived from or contacted a listed waste source:

a. LABEL container with a completed Hazardous Waste Label

b. LABEL container with the major risk.

1. IF major risk is not known, CONTACT HMC for guidance).

c. MOVE container to a 90-Day accumulation area per LO-100-166.

6.13.5 IF waste is not known to have been derived from or contacted a listed waste source:

a. LABEL container as Low-Level Radioactive waste and manage per section 6.6 of this procedure.

b. DOCUMENT all corrective actions per the Radiological Problem Report. 
HNF-5443, rev. 0

\section{WASTE MANAGEMENT LABORATORY \\ SEGREGATE AND MANAGE SOLID LABORATORY WASTES \\ LO-100-151}

PAGE 29 of 38

REV/CHANGE NO. E-4

Printed: November 12, $19992: 23 \mathrm{pm}$

EFFECTIVE DATE 11/16/99

\subsection{Collect and Manage Solid Chemical Waste}

\section{NOTE}

I

i

Whether managing solid chemical wastes as Low-Level Radioactive or Solid Mixed waste the

miscellaneous section on the Waste Contents Sheet must have the constituents, procedure number, or test Lplan listed.

6.14.1 MANAGE solid chemical wastes as instructed by the solid waste stream fact sheet.

a. DISPOSE of nonhazardous solid chemical wastes as Low-Level Radioactive waste per Section 6.6 of this procedure.

b. DISPOSE of hazardous/mixed solid chemical waste either as solid mixed waste per Section 6.8 , or as solid chemical mixed waste per this section.

6.14.2. OBTAIN an approved container if required.

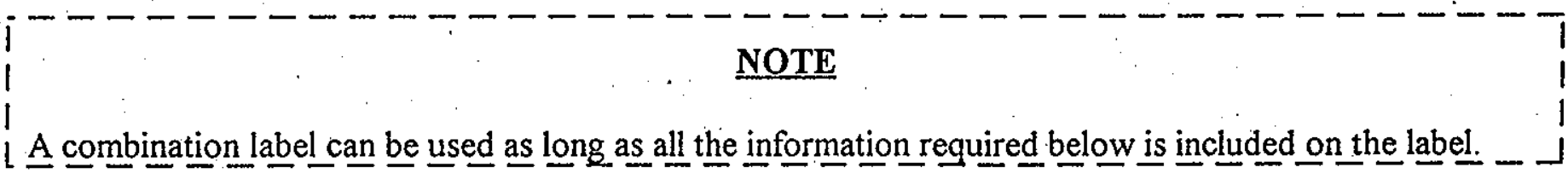

6.14.3 LABEL waste or waste container with the following:

a. A completed Waste Stream Label obtained form the Solid Waste Stream Fact Sheet (SWSFS) per WMH-310, Section 6.1.

b. A Hazardous Waste Label.

c. Major risk (i.e., flammable, corrosive, etc.).

d. Room number and hood number (if applicable).

6.14.4 PLACE solid chemical waste into container (if one is used).

6.14.5 COMPLETE Waste Contents Sheet as follows:
a. Record size of container
b. Record percentages of waste
c. Record room number 
HNF-5443, rev. 0

\section{WASTE MANAGEMENT LABORATORY \\ SEGREGATE AND MANAGE SOLID LABORATORY WASTES \\ LO-100-151}

d. Record hood number

e. Record the date

f. Print your name.

6.14.6 DOUBLE BAG container or waste, HORSETAIL and

TAPE bags.

- Outer bag must be yellow.

6.14.7 ENSURE outer bag has no removable contamination.

6.14.8 ENSURE the container is labeled and dose rate established by HPT is written on the container prior to transferring to Room $4 \mathrm{E}$.

6.14.9. CONTACT HMC or shift manager for access to Room 4E 90-Day accumulation area.

a. SHIELD container if reading $100 \mathrm{mr} / \mathrm{hr}$ or greater.

6.14.10 TRANSFER waste to Room 4E 90-day accumulation area.

6.14.11 PLACE package into 90-day accumulation area.

6.14.12 LOG container into 90-day accumulation area per procedure LO-100-166. 
HNF-5443, rev. 0

\section{WASTE MANAGEMENT LABORATORY \\ SEGREGATE AND MANAGE SOLID LABORATORY WASTES \\ LO-100-151}

PAGE 31 of 38

REV/CHANGE NO. E-4

Printed: November 12, 1999 2:23pm

EFFECTIVE DATE $11 / 16 / 99$

\subsection{Routine Cubicle Waste Load-Out}

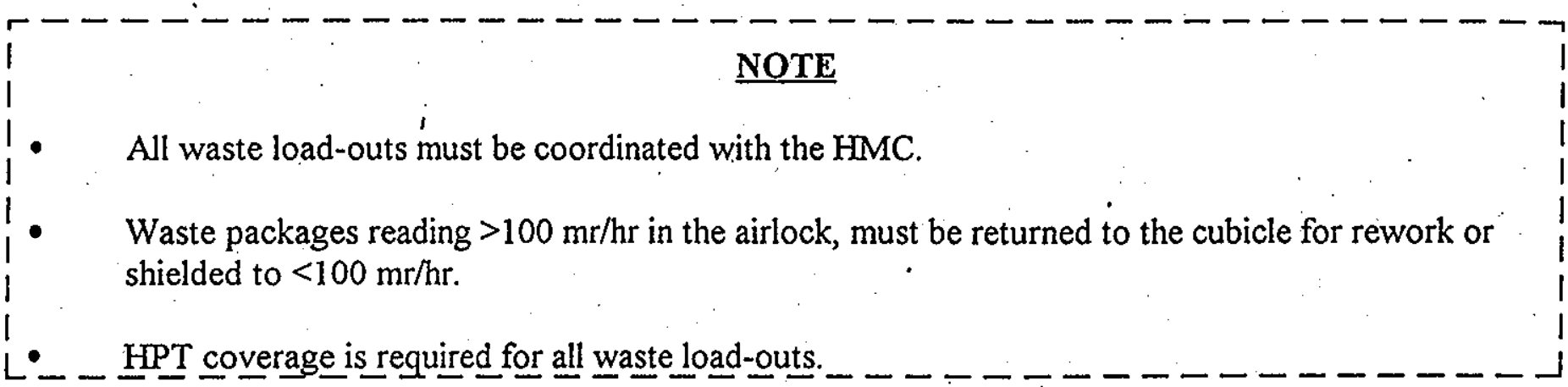

6.15.1 LOAD IN/OUT of sample/equipment according to cubicle operating procedures

LO-100-110 and LO-161-172.

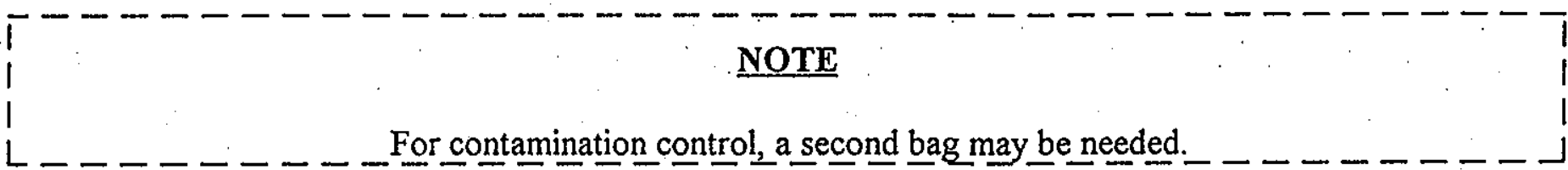

6.15.2 PLACE container in a plastic bag,

HORSETAL, and

TAPE.

- $\quad$ Outer bag must be yellow.

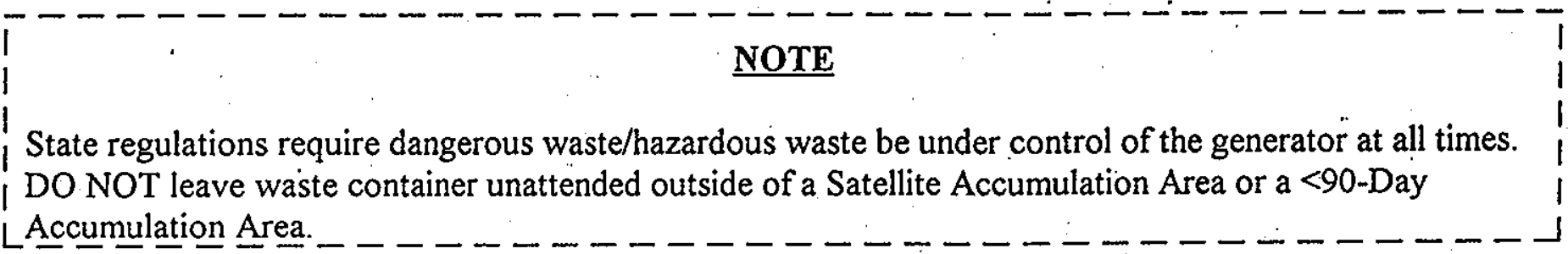

\section{WARNING}

Do not leave waste container unattended. It must be stored in an approved 90 -day accumulation area or satellite accumulation area.

6.15.3 PLACE bagged waste container on a cart and then:

a. HAVE HPT perform a 6-point survey on the container.

1. FILL out the 6-point survey data sheet. 


\section{WASTE MANAGEMENT LABORATORY \\ SEGREGATE AND MANAGE SOLID LABORATORY WASTES \\ LO-100-151}

PAGE 32 of 38

REV/CHANGE NO. E-4

Printed: November 12, $19992: 23 \mathrm{pm}$

EFFECTIVE DATE $11 / 16 / 99$

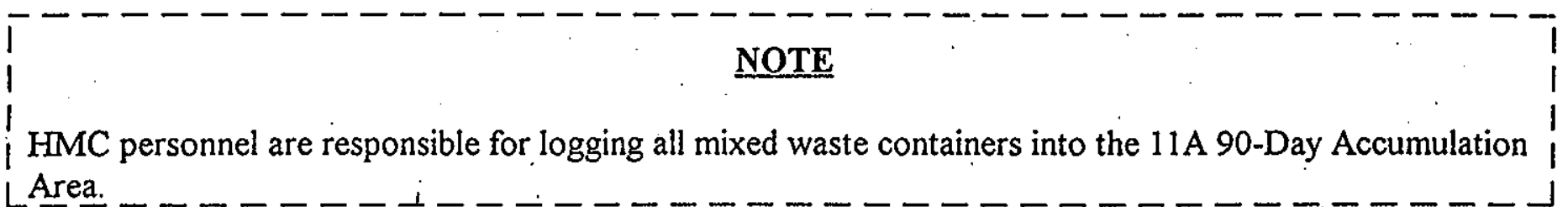

Area.

b. TRANSPORT container to the 11A 90-Day Accumulation Area as coordinated and directed by the HMC.

c. PROVIDE HMC with completed 6-Point Survey data Sheet for the container.

\subsection{Filling out the 6-Point Survey Data Sheet}

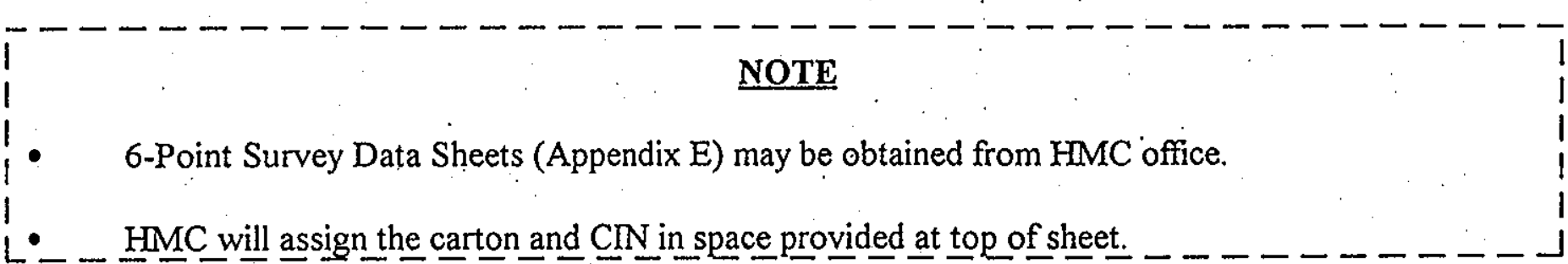

6.16.1 CIRCLE the size of the inner container used or

PRINT the size of the container in the "other" space provided.

6.16.2 INDICATE the number of layers of lead and/or rubber shielding used.
a. IF none is used
THEN CIRCLE "0".

6.16.3 CIRCLE the size of the outer container used.
a. IF no outer container is used
THEN CIRCLE "NO CAN".

6.16.4 INDICATE the number of layers of lead and/or rubber shielding used.

a. IF none is used

THEN CIRCLE "0".

6.16.5 FILL IN the waste percentages box at the bottom of the page.

a. RECORD the gross weight of the inner container.

- HMC will figure the weight of the waste in the container. 
WASTE MANAGEMENT LABORATORY

SEGREGATE AND MANAGE SOLID LABORATORY WASTES

LO-100-151

PAGE, 33 of 38

REV/CHANGE NO. E-4

Printed: November 12, 1999 2:23pm

EFFECTIVE DATE 11/16/99

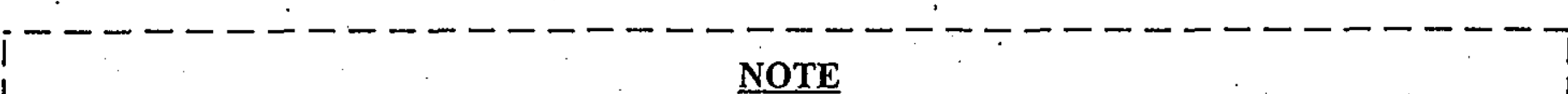

I $\ldots \ldots-\ldots$ Percentages DO NOT include shielding, inner or outer containers.

b. ESTIMATE the percentage of each waste type in container by volume.

c. WRITE in room number or area in which the waste was generated.

d. WRITE in the tank number of the sample from which the waste was generated.

- When more than two tanks are present use the $219-\mathrm{S}$ as the tank number.

e. WRITE in the date in which the form was filled out.

f. PRINT name and sign the sheet.

6.16.6 ASSIGN the carton number and CIN in space provided at top of sheet.

6.16.7 ATTACH the 6-Point Survey Data Sheet to container and give to HMC.

\subsection{RECORDS}

Waste Contents Sheet and 6-Point Survey Data Sheet are records maintained by HMC. 
WASTE MANAGEMENT LABORATORY

SEGREGATE AND MANAGE SOLID LABORATORY WASTES

LO-100-151

Appendix A. Example of Magnetic Compactible Waste Contents Sheet Sign

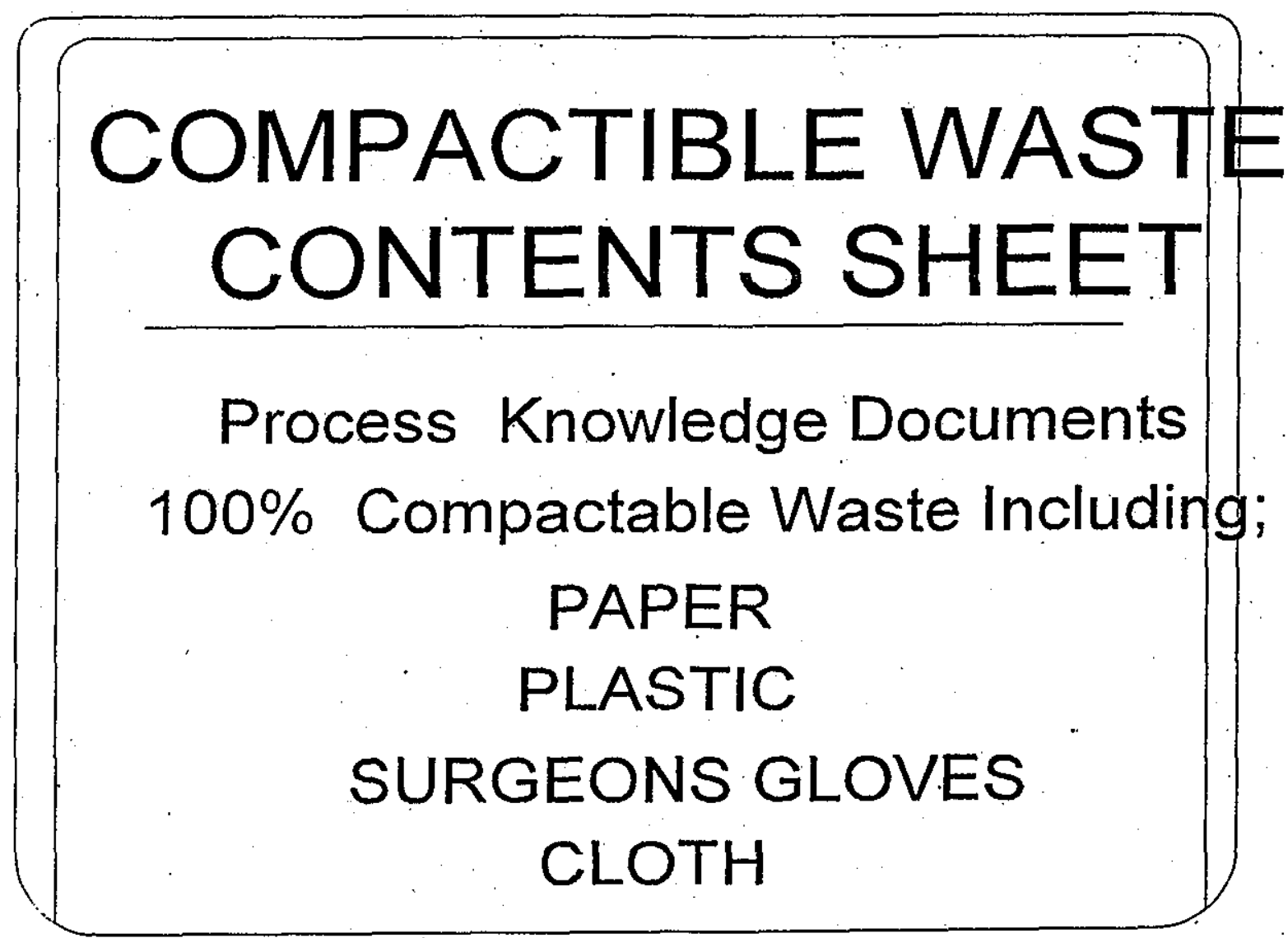




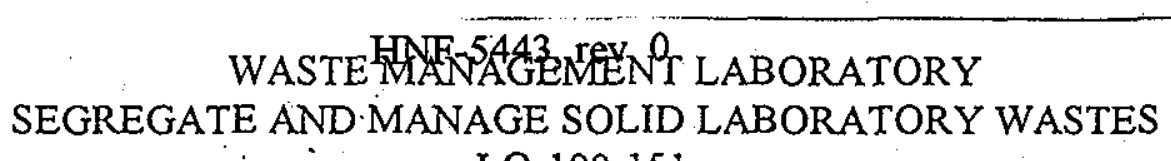

LO-100-151

PAGE 35 of 38

Appendix B. Example of Waste Contents Sheet

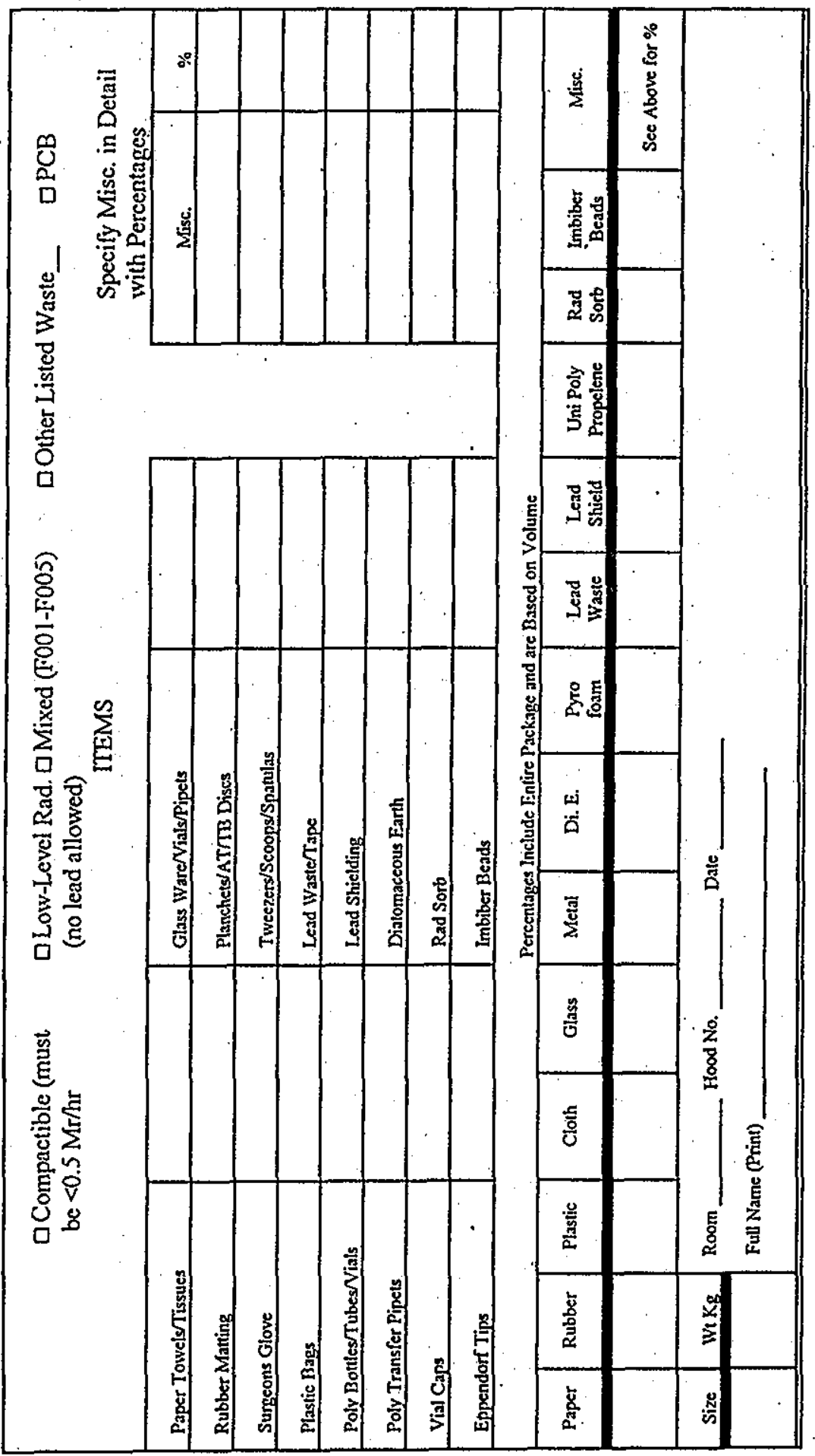


Appendix C. Example of 222-S Hazardous Waste Labels

(Pink background, black lettering)

HAZARDOUS WASTE
F-LISTED MIXED WASTE
ROOM NO._ HOOD NO.
WASTE CODES: F001, F002, F003, F004, F005
TOXIC

(Periwinkle background, black lettering)

HAZARDOUS WASTE MIXED WASTE

ROOM NO._ HOOD NO.

WASTE CODES: 


\section{WASTE MANAGEMENT LABORATORY}

SEGREGATE AND MANAGE SOLD LABORATORY WASTES

LO-100-151

\section{Appendix D. Waste Container Preparation}

\section{Inner Container}
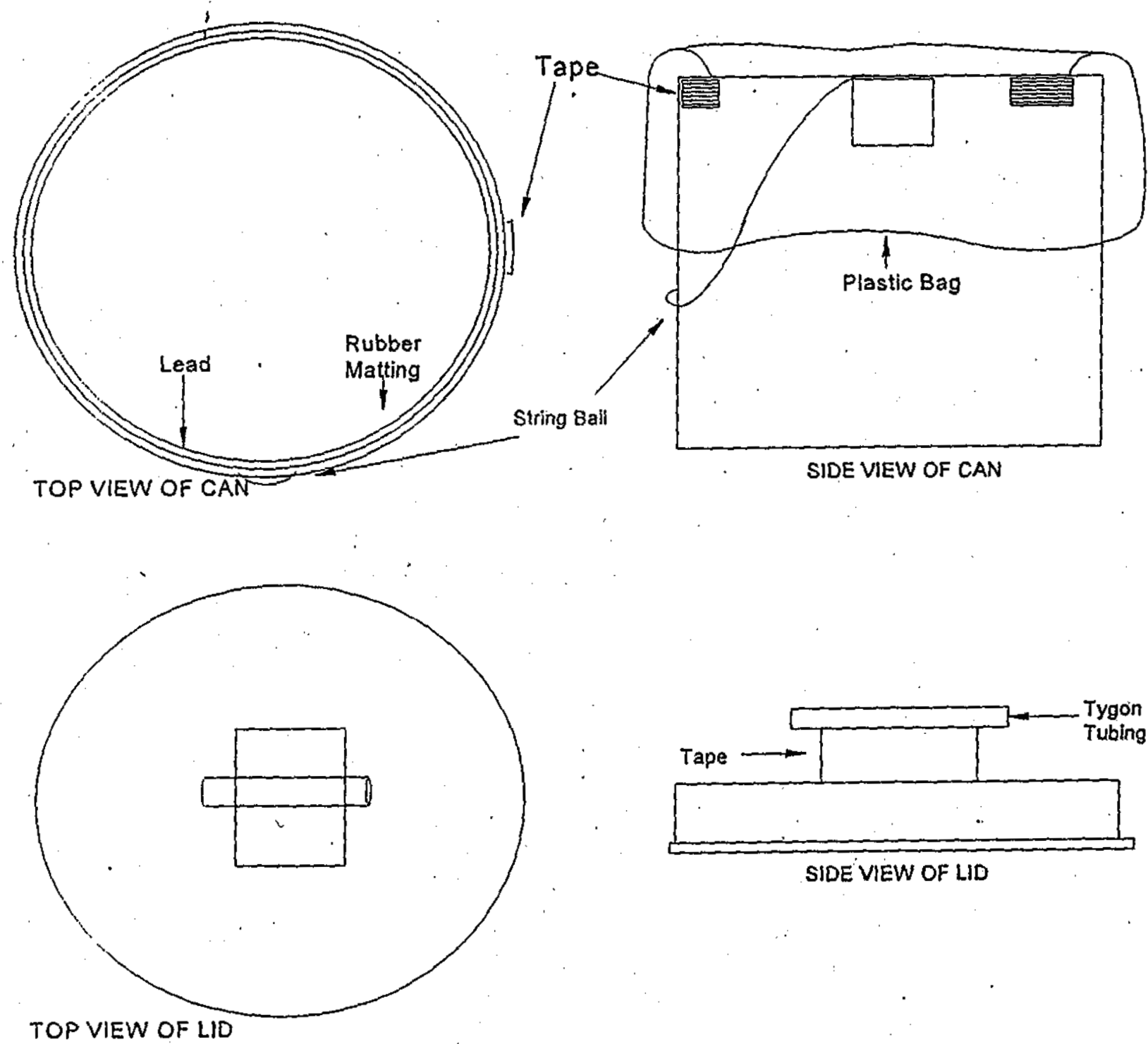


\section{HNF-5443, rev. 0 \\ WASTE LATH NENO LABORATORY \\ SEGREGATE AND MANAGE SOLID LABORATORY WASTES \\ LO-100-151}

\section{Appendix E. Example of 6 Point Survey Data Sheet}

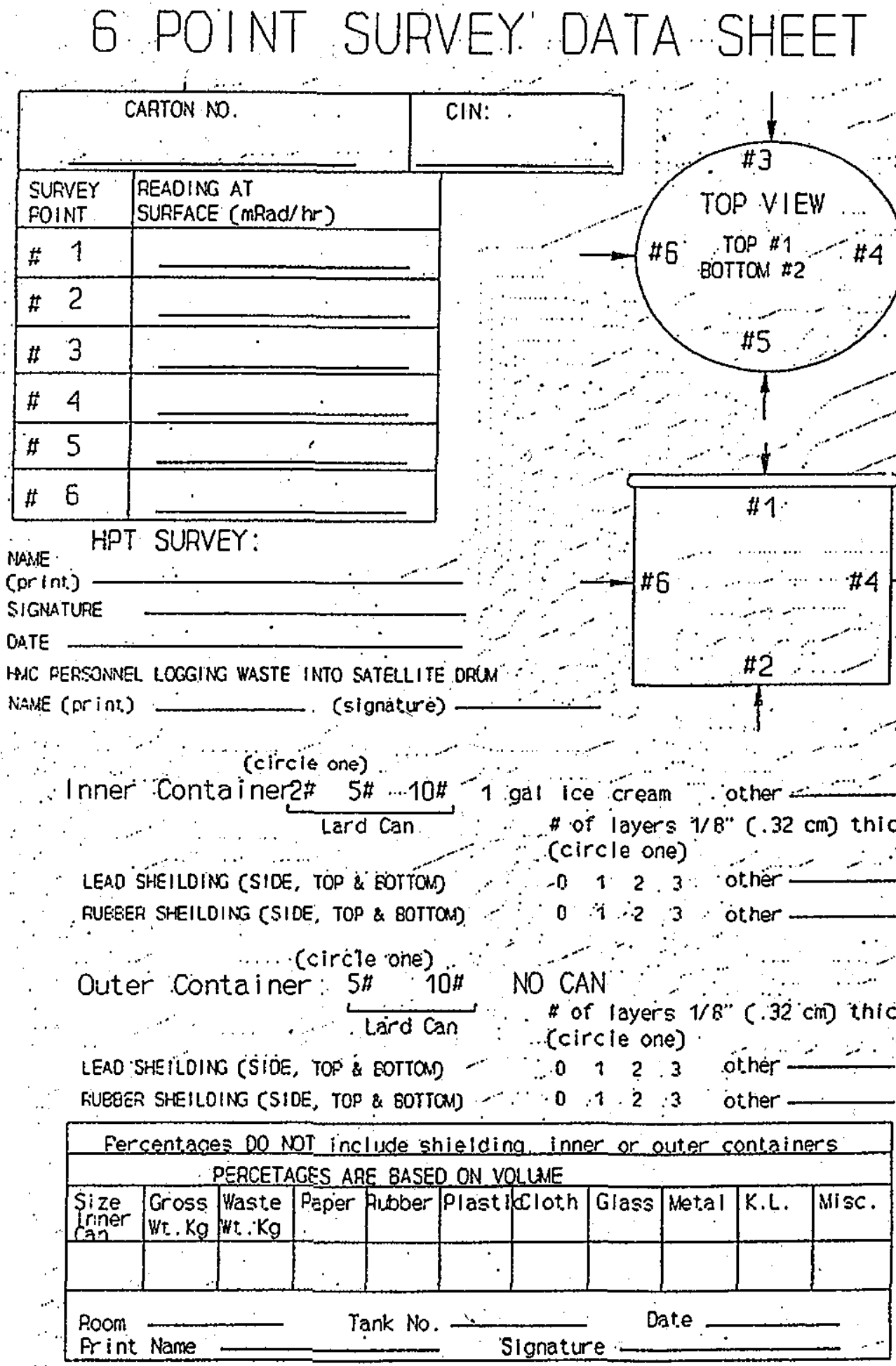


HNF-5443, rev. 0

Appendix B

LO-160-101

1E-2 Hot Cell Airlock

Operations

B- 1 


\section{APPROVAL DESIGNATOR ES \\ Procedure Use Level CONTINUOUS}

TABLE OF CONTENTS

PAGE

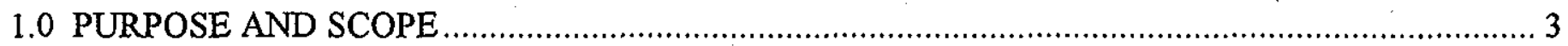

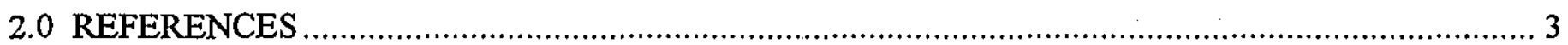

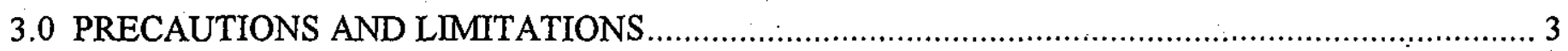

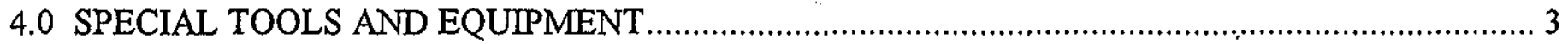

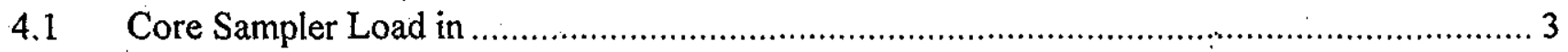

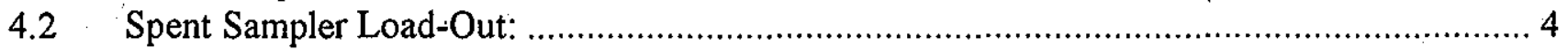

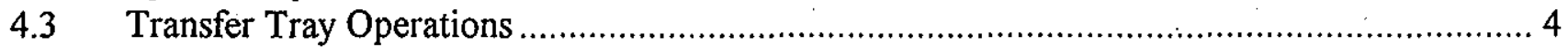

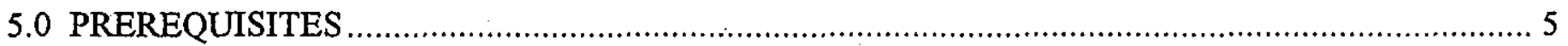

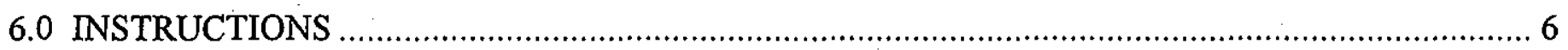

6.1 Replacement of Airlock Plug with PVC Transfer-Tube...................................................... 6

6.2. Replacement of PVC Transfer-Tube with Airlock Plug ...................................................... 7

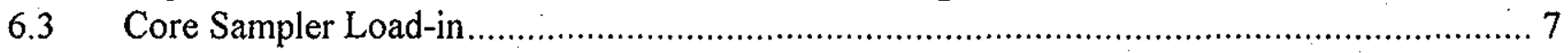

6.4 Unloading of Sampler and Liner from 1E-2 Hot Cell .......................................................10

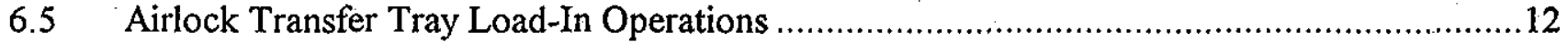

6.6 Airlock Transfer Tray Load-Out Operations...................................................................13

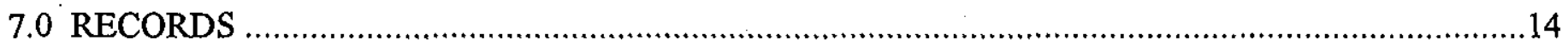


HNF-5443, rev. 0

WASTE MANAGEMENT LABORATORY

1E-2 HOT CELL AIRLOCK OPERATIONS

LO-160-101

PAGE 2 of 14

REV/CHANGE NO..H-2

Printed: December 16, 1999 2:55PM EFFECTIVE DATE 11/19/1999

\section{Revision Status}

Change

Level

F-1

Date

$11 / 10 / 98$

G-0

$11 / 12 / 98$

$98-26$

$\mathrm{H}-\mathrm{O}$

$03 / 23 / 99$

99-07

All

All

Page(s)

All

98-67

H-1

$06 / 09 / 99$

$99-40$

$11 / 19 / 99$

$\mathrm{H}-2$

99-140

6
Description

Incorporate Field Change 222-98105 to incorporate enhanced radiological work planning for sample portions. Reformat.

Changes to maintain compliance with current operating procedures.

Consolidate objectives, activities of two procedures into one and limits the application of this procedure to only one hotcell and its airlock.

Change from reference to continuous use.

Add procedure step caveat 


\subsection{PURPOSE AND SCOPE}

This procedure describes steps necessary to perform operations involving use or change in configuration of 1E-2 airlock. The scope of this procedure includes all aspects for airlock utilization including: load-in and load-out operations via airlock transfer tray, load-in and load-out operations via transfer-tube, and airlock configuration to support either of these modes.

\subsection{REFERENCES}

Not applicable.

\subsection{PRECAUTIONS AND LIMITATIONS}

This procedure shall be used only in situations where the field dose rate is less than $50 \mathrm{mrem} / \mathrm{hr}$ at $30 \mathrm{~cm}$; or as specified in the RWP; or whichever is lower.

Application of this procedure requires authorization by one or more Radiation Work Permits (RWP).

This procedure should be performed under direction of a cognizant lead worker who shall be present at work site during entire work function.

The lead worker should conduct a thorough pre-job briefing with all task personnel present including Health Physics Technician (HPT) immediately before performing job task.

\subsection{SPECIAL TOOLS AND EQUIPMENT}

\section{4_1 Core Sampler Load in:}

1E Bridge Crane (trained operator use only)

Airlock configured with transfer tube (PVC, 30" $\times 4-1 / 2$ " OD)

Box wrench to fit cask bolt(s)

Cask table

Gloves: leather or canvas

Hex wrench to fit cask plug 
HNF-5443, rev. 0

WASTE MANAGEMENT LABORATORY

1E-2 HOT CELL AIRLOCK OPERATIONS

LO-160-101

PAGE 4 of 14

REV/CHANGE NO. H-2.

Printed: December 16, 1999 2:55PM EFFECTIVE DATE 11/19/1999

Plastic bags: yellow, assorted capacities

Plastic sheeting or Kraft paper

Plastic sleeving: clear, 6-foot sections

Ramrod.w/plastic sheath, steel, 1/4" diameter, 5 feet long

Safety shoes

Tape: masking and green duct

\section{4_2 Spent Sampler Load-Out:}

Plastic sheeting/Kraft paper

Plastic bags: yellow, assorted capacities

Plastic sleeving: yellow, reinforced

Plastic sleeving: clear, six foot sections

Tape: masking and green duct

Airlock configured with transfer tube (PVC, 30" $\times 4-1 / 2^{\prime \prime}$ OD)

\subsection{Transfer Tray Operations}

Plastic sheeting/Kraft paper

Plastic bags: yellow, assorted capacities

Tape: masking and green duct 
HNF-5443, rev. 0

\section{WASTE MANAGEMENT LABORATORY \\ 1E-2 HOT CELL ATRLOCK OPERATIONS \\ LO-160-101}

PAGE 5 of 14

REV/CHANGE NO. H-2

Printed: December 16, 1999 2:55PM EFFECTIVE DATE 11/19/1999

\subsection{PREREQUISITES}

Sections 6.1 through 6.5 of this procedure each contain steps necessary to complete the particular task. Therefore, tasks involving any of these sections may be performed alone or in any sequence necessary provided that all the steps in each section are performed precisely as ordered.

Work requiring overhead bridge crane use shall commence with a pre-use crane and rigging inspection per LO-161-110. Only one qualified person should be designated as hoist operator and shall be the only person operating the hoist during the job task. Furthermore, the hoist operator should know the hoist emergency circuit breaker location.

Personnel involved in this job task should wear safety shoes and canvas or leather gloves where appropriate when moving and hoisting casks. 
HNF-5443, rev. 0

WASTE MANAGEMENT LABORATORY

1E-2 HO'T CELL AIRLOCK OPERATIONS

PAGE 6 of 14

\subsection{INSTRUCTIONS}

\section{NOTE:}

Sections, or steps within sections, of this procedure may be performed out of sequence, as required.

\subsection{Replacement of Airlock Plug with PVC Transfer-Tube}

6.1 1 REQUEST HPT to survey airlock and vicinity for dose rate and contamination.

a $\quad$ CONSULT HPT for radiological conditions and instructions.

6,122 REMOVE plug from outer airlock door.

a DECONTAMINATE or

DOUBLE-BAG plug as necessary.

b、 STORE plug as appropriate.

c. DECONTAMINATE airlock as necessary.

6.1.3 INSERT PVC transfer tube (without cap) into 1E-2 airlock through port in outer airlock door.

6 1.4 TAPE one end of a 6-ft section of 12-in. diameter polyethylene sleeve to airlock door or barrel of PVC transfer tube.

$6 \div 1.5$ HORSETALL other end of polyethylene sleeve.

$6,1,6 \quad$ PLACE cap over end of transfer-tub and polyethylene sleeve.

6.1.7 REQUEST HPT to survey area for contamination.

a DECONTAMINATE are as necessary.

b. PERFORM housekeeping as appropriate.

c. DISPOSE of accumulated waste per LO-100-151. 
HNF-5443, rev. 0

WASTE MANAGEMENT LABORATORY

1E-2 HOT CELL AIRLOCK OPERATIONS

PAGE 7 of 14

LO-160-101

REV/CHANGE NO. H-2

Printed: December 16, 1999 2:55PM EFFECTIVE DATE 11/19/1999

\subsection{Replacement of PVC Transfer-Tube with Airlock Plug}

$6,2,1 \quad$ REQUEST HPT to survey the airlock and vicinity for dose rate and contamination.

a CONSULT HPT for radiological conditions and instructions.

b PULL PVC transfer-tube into plastic sleeving attached to outer airlock door until transfer-tube is free of the penetration.

$6,2,2$ DETACH plastic sleeving from outer airlock door.

6.2 3 REQUEST HPT to survey bagged transfer tube for dose rate and contamination.

a DECONTAMINATE and store transfer-tube as appropriate.

$6,2,4 \quad$ REQUEST HPT to survey airlock for contamination.

a DECONTAMINATE area as necessary.

6.2、5 INSERT plug into outer airlock door.

$6.2,6$ REQUEST HPT to survey area for contamination.

$6,2,7$ DECONTAMINATE area as necessary.

a. PERFORM housekeeping as appropriate.

b. DISPOSE of accumulated waste per LO-100-151.

\section{Core Sampler Load-in}

6.3 12 PLACE appropriately sized polyethylene bag into waste collection can attached to cask table to collect any particulates, liquids, or loose materials which may fall out of the cask.

6.3.2 REQUEST HPT to survey cask and airlock vicinity for dose rate and contamination.

a $\quad$ CONSULT HPT for radiological conditions and instructions.

$6,3,3$. REMOVE bail bolts. 
HNF-5443, rev. 0

WASTE MANAGEMENT LABORATORY

1E-2 HOT CRLL AIRLOCK OPERATIONS

LO-160-101

PAGE 8 of 14

6,3_4 REQUEST HPT to survey bail bolts for contamination.

a DECONTAMINATE bail bolts as necessary.

6,3,5 ATTACH hoist to cask bail.

a APPLY duct tape to lifting hook to "mouse" the hook closed.

b . LIFT cask out of dolly.

c. REMOVE dolly from under cask.

$6,3,6 \quad$ RELEASE spring locks on cask bail.

6,3 7 LOWER cask horizontally onto cask table.

$6,3 \_8 \quad$ PLACE end of 12-inch diameter sleeve over end of closed cask and tape to base of cask flange.

6.3.9 PULL remaining sleeve over cask until sleeve is bunched, leaving cask lid clear for removal.

6,3,10 REMOVE PVC cap.

6_3 11 REQUEST HPT to survey PVC cap for contamination.

a DECONTAMINATE PVC cap as necessary.

6 3,12 PLACE any items suitable for load-in into transfer-tube:

6,3,13 UNTAPE end of old sleeving from face of outer airlock door.

6,3,14 REMOVE lid bolts.

6,3,15 REQUEST HPT to survey lid bolts for contamination.

a DECONTAMINATE lid boits as necessary.

6,3,16 REMOVE cask lid. 
HNF-5443, rev. 0

WASTE MANAGEMENT LABORATORY

1E-2 HOT CELL AIRLOCK OPERATIONS

LO-160-101

PAGE 9 of 14

REV/CHANGE NO. H-2

Printed: December 16, 1999 2:55PM EFFEOTIVE DATE 11/19/1999

6,3 $\checkmark 17$ REQUEST HPT to survey cask lid for contamination.

a DECONTAMINATE as necessáry.

6,3,18 ALIGN cask with transfer-tube opening.

6 3,19 PULL sleeving over cask/transfer-tube interface and tape to face of airlock door.

6,3,20 HOLD absorbent smear material under cask plug to catch loose material.

a REMOVE plug from bottom of cask, using appropriate wrench.

6.3.21 REQUEST HPT to survey plug for contamination.

a DECONTAMINATE plug and cask as necessary.

6,3 22 POSITION plastic-covered ramrod through bottom of cask.

6_3 23 USE ramrod to push liner/sampler assembly into transfer-tubé.

$6 \_3 \_24$ OPEN inner airlock door.

6_3 25 CONTINUE pushing liner/sampler assemble into transfer-tube.

6_3_26 PULL liner/sampler assemble completely into hot cell.

6_3_27 CLOSE inner airlock door.

6,3_28 RETRACT ramrod into its sleeving.

6 3 3 29 DECONTAMINATE ramrod and sleeving as appropriate.

6,3,30 SCREW plug back into cask.

6,3,31 DECONTAMINATE bottom of cask as necessary.

$6 \_3,32$ UNTAPE polyethylene sleeve from cask.

a HORSETAIL end of polyethylene sleeve. B- 10

6_3,33 REPLACE cap over transfer-tube. 
WASTE MANAGEMENT LABORATORY

1E-2 HOT CELL ATRLOCK OPERATIONS

PAGE 10 of 14

LO-160-101

6.3.34 REPLACE lid on cask.

a REPLACE lid bolts (finger tight).

6,3 35 LIFT cask from cask table.

a RETURN cask to vertical orientation.

6_3 36 REQUEST HPT to survey cask for external removable contamination.

a DECONTAMINATE exterior of cask as appropriate for release from contamination area.

6 3 3 LOWER cask vertically back into dolly.

a DISCONNECT hoist from cask bail.

b. REPLACE bolts in bail (finger tight).

6,3,38 STORE cask and dolly as appropriate.

a $\quad$ APPLY identification labels and RADCON survey labels (as directed by HPT) as appropriate for release from contamination area.

6,3 39 REQUEST HPT to survey airlock vicinity and work area for contamination.

$6,3,40 \quad$ DECONTAMINATE area as necessary.

6_3,41 PERFORM housekeeping as appropriate.

6 3ـ42 DISPOSE of accumulated waste per LO-100-151.

6.4 Unloading of Sampler and Liner from 1E-2 Hot Cell

6.4 REQUEST HPT survey airlock vicinity for dose rate and contamination.

a CONSULT HPT for radiological conditions and instructions.

6.422 REMOVE cap from transfer-tube.

6,4、3 PUSH spent sampler/liner into transfer-tube. 
HNF-5443, rev. 0

WASTE MANAGEMENT LABORATORY

1E-2 HOT CELL ATRLOCK OPERATIONS

LO-160-101

PAGE 11 of 14

$6,4,4 \quad$ CLOSE inner airlock door.

$6 \checkmark 4,5 \quad$ PULL sampler/liner out of transfer-tube and into polyethylene sleeve.

6.4 6 TWIST sleeving closed approximately 4-6 inches beyond open end of sampler/liner.

$6,4,7 \quad$ APPLY duct tape across twist and cut across tape.

a COVER each end of horsetailed sleeve with piece of tape.

6.48 DOUBLE-BAG sampler/liner with another polyethylene sleeve using yellow mesh reinforced plastic material.

a $\quad$ HORSETAIL both ends of outer sleeve (bag).

b $\quad$ APPLY extra duct tape to each end of the double-bagged sampler/liner to prevent chaffing of the plastic sleeving during handling.

644 REQUEST HPT to survey double-bagged sampler/liner for exterior removable contamination and dose rate.

a DECONTAMINATE double-bagged sampler/liner as appropriate for release from the contamination area.

b. APPLY identification labels and RADCON survey labels (as directed by HPT) as appropriate for release from contamination area.

c. STORE double-bagged liner and sampler as appropriate.

6.4,10 REPLACE PVC cap on transfer-tube.

6.4_11 REQUEST HPT to survey airlock vicinity and work area for contamination.

a DECONTAMINATE area as necessary.

b PERFORM housekeeping as appropriate.

c DISPOSE of accumulated waste per LO-100-151. 


\section{WASTE MANAGEMENT LABORATORY}

1E-2 HOT CELL AIRLOCK OPERATIONS

LO-160-101

PAGE 12 of 14

\subsection{Airlock Transfer Tray Load-In Operations}

6 6 5 1 REUEST HPT to survey airlock vicinity for dose rate and contamination.

a CONSULT HPT for radiological conditions and instructions.

6,5,2 ENSURE airlock inner door is completely closed.

$6,5,3 \quad$ POSITION transfer tray near airlock outer door.

$6,5,4 \quad$ OPEN airlock outer door.

6,5 5 REQUEST HPT to survey airlock vicinity for dose rate and contamination.

6,5,6 CONSULT HPT for radiological conditions and instructions.

$6,5,7 \quad$ PLACE toweling on tray.

6 5 5 8 PLACE materials to be loaded in onto tray so it can be easily grasped with manipulator.

6_5_9 CLOSE airlock outer door.

$6,5,10$ OPEN airlock inner door.

$6,5,11$ EXTEND transfer tray into hot cell.

6,5,12 REMOVE material from transfer tray.

6_5_13 RETRACT transfer tray back into airlock.

$6,5,14$ CLOSE airlock inner door.

$6,5,15 \quad$ OPEN airlock outer door.

6,5,16 REQUEST HPT to survey airlock vicinity for dose rate and contamination.

a. CONSULT HPT for radiological conditions and instructions.

6,5,17 REMOVE toweling from airlock.

B-13

6,5,18 DECONTAMINATE airlock and tray as necessary. 
HNF-5443, rev. 0

\section{WASTE MANAGEMENT LABORATORY}

1E-2 HOT CELL AIRLOCK OPERATIONS

LO-160-101

PAGE 13 of 14

$6,5,19 \quad$ CLOSE airlock outer door.

6 5 5 20 REQUEST HPT to survey airlock vicinity and work area for contamination.

a DECONTAMINATE area as necessary.

b. PERFORM housekeeping as appropriate.

c DISPOSE of accumulated waste per LO-100-151.

\section{6_6 Airlock Transfer Tray Load-Out Operations}

6,6、1 . REQUEST HPT to survey airlock vicinity for dose rate and contamination.

a CONSULT HPT for radiological conditions and instructions.

6,6,2 ENSURE airlock inner door is completely closed.

$6 \_6 \_3$ OPEN airlock outer door:

6.6 4 REQUEST HPT to survey airlock vicinity for dose rate and contamination.

a CONSULT HPT for radiological conditions and instructions.

6 6 5 PLACE toweling on tray to prevent spread of contamination.

6_6_6 CLOSE airlock outer door.

$6 \_6,7$ OPEN airlock inner door.

6.6 8 EXTEND tray into hot cell.

6,6 9 PLACE material onto tray.

6_6,10 RETRACT transfer tray into airlock.

$6,6,11$ CLOSE inner airlock door.

$6 \_6,12$ OPEN outer airlock door. 
HNF-5443, rev. 0

WASTE MANAGEMENT LABORATORY

1E-2 HOT CELL ATRLOCK OPERATIONS

LO-160-101

PAGE 14 of 14

REV/CHANGE NO. H-2

Printed: December 16, 1999 2:55PM EFFECTIVE DATE 11/19/1999

6_6,13 REQUEST HPT to survey airlock vicinity for dose rate and contamination.

a $\quad$ CONSULT HPT for radiological conditions and instructions.

$6 \_6 \_14 \quad$ REMOVE items according to good RADCON practice.

a DECONTAMINATE airlock as necessary.

$6,6,15$ CLOSE outer airlock door.

6.6_16 REQUEST HPT to survey airlock vicinity and work area for contamination..

a DECONTAMINATE area as necessary.

b_ PERFORM housekeeping as appropriate.

c. DISPOSE of accumulated waste per LO-100-151.

\subsection{RECORDS}

Not Applicable. 
HNF-5443, rev. 0

\section{Appendix C}

LT-160-101

Retained Gas Sampler

Operation

C- 1 
HNF-5443, rev. 0

WASTE MANAGEMENT I.ABORATORY

Laboratory Technology Procedure

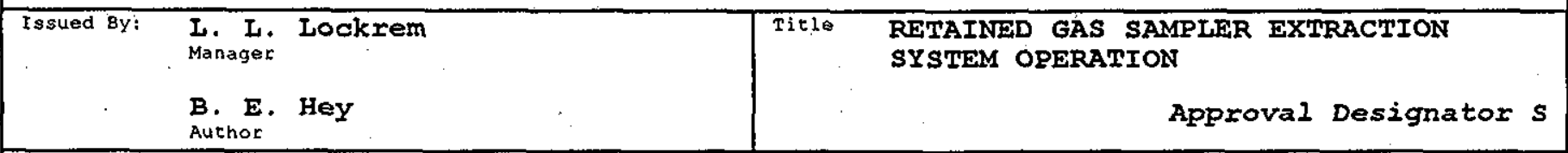

\subsection{SUMMARY}

This procedure is used to extract and separate retained gas from a waste tank core sample for quantitative analysis.. The waste tank core segment sample is delivered to the laboratory in a special gas tight waste tank core sampler that contains the gas phase component of waste tank sample material along with the bulk material. Normally the sampler is loaded into the 1E-2 hot cell according to procedure L0-160-101, Core Segment Load-in and Load-out of 1E-2 Hot Cell.

The Sampler is coupled to the extractor of the Retained Gas Sampler (RGS). system in a way that ensures vacuum integrity. Then, the extractor is evacuated. Vapors contained inside the core sampler are extruded into the extractor with the bulk sample material then are pumped, using a liquid mercury positive displacement pump, to collection canisters located outside the hot cell. A high-efficiency in-line depth filter prevents the transfer of radioactive particles to the collection canisters. The collection canisters can be removed from the system for analysis of the gases.

\subsection{APPLICATIONS}

This procedure applies to activities involved in processing RGS samples and using the RGS Extraction System to identify and quantify vapors associated with core segments.

\subsection{LIMITATIONS}

The complete RGS system consists of more than 20 valves and includes filters, vacuum pumps, liquid mercury, pressure transducers, and thermocouples among its components. Because the system can be damaged if it is operated incorrectly, only persons trained to operate the system shall perform this work.

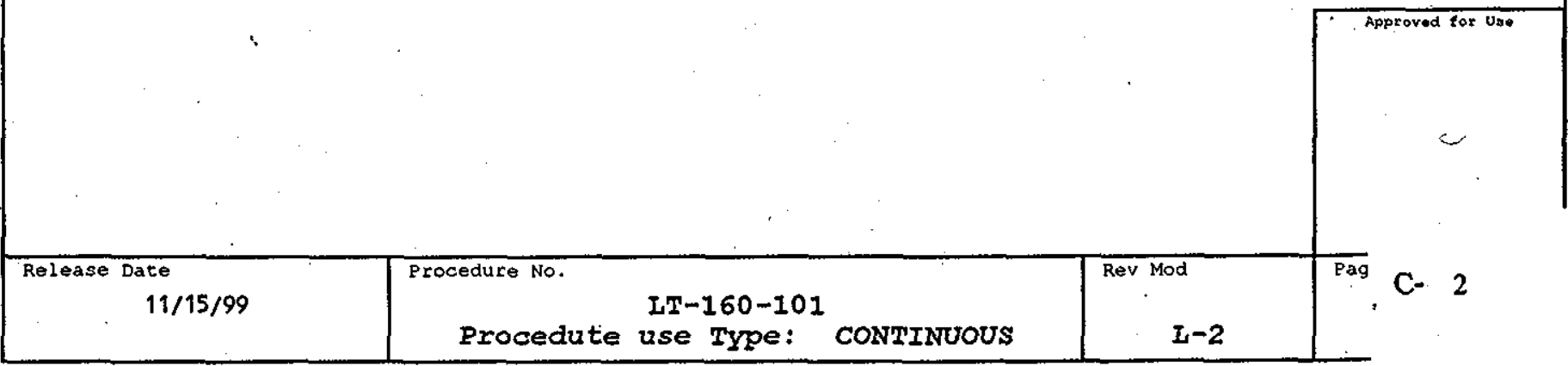




\subsection{QUALITY CONTROI RROTOCOL}

Data obtained during this procedure include temperature and pressure readings. Log sheets on which data are recorded are pasted into a controlled laboratory notebook. (Usually telefacsimiles of the data sheets are transmitted out of the (aboratory to avoid time and expense of radiological survey.)

Temperature measurements are provided through use of $K$-type thermocouples. Cal ibration of the temperature sensing capability of the RGS system is not routinely performed; rather several readings are acquired simultaneousty from different locations of the RGS system for redundant verification.

Four of the five pressure measurements are made using instruments which are calibrated annually; the fifth (non-calibrated) pressure measuring instrument is used for convenient indication only. Usually the calibrations are performed by the manufacturer at the factory.

\subsection{SAEETY (Continued)}

\subsection{WASTE GENERATION}

No solid chemical waste is generated when performing this procedure since spent sample material is saved for other unrelated studies. Contaminated rinse water which is generated during preparation and post processing washdowns is expelled to the hot cell drain. The Building operations Manager should be notified prior to washdown activities or anytime water is used in the hot cell.

Procedure No.
IT-160-101
Procedure use Type: CONTINUOUS


HNF-5443, rev. 0

\subsection{QUALITY CONTROL PROTOCOY (Continued)}

\subsection{SAFETY}

The RGS extraction system may involve using compressed gases which are used to purge the system periodically. Although these gases are regulated to low and easily manageable pressures, care should be exercised to ensure the system does not exceed $133 \mathrm{kPa}(4.6 \mathrm{psig})$ so that sensitive instruments will not be damaged. When not in use the cylinders' valves should be closed.

The RGS extraction system uses liquid mercury in the displacement pump. Although the mercury is safely contained within the system, care should be exercised when performing plumbing operations on the system because beads of mercury may be encountered when breaching some systern lines. If a spitt of metaltic mercury does occur, the Shift operations Manager (SOM) must be notified and a spiti clean-up plan initiated according HNFIP-0263-222S, Buitding Emergency. Plan for 222-S Complex.

In the event that the system lines and plumbing should be breached to effect repair or replacement of instruments or fittings, an HPT must be present to conduct surveys to monitor and control the spread of radioactive contamination.

7.0 REAGENTS

Ammonium hydroxide solutions $0.04 \mathrm{M}$, solutions containing specific non-radioactive isotopes.

\subsection{EQUTPMENT}

Gas Sample Collection Canisters (H-2-821611)

Laboratory Notebook, controlled

Retained Gas Sampler System ( $H-2-821609)$

Manifold System Control Cabinet (H-2-85291) and Contents:

Data Acquisition Control Unit, DACU

Mercury Positive Displacement Pump

Pressure Transducers and Display Panels

Motor Controllers Computer Power Supplies

Turbo-Molecular Vacuum Pump

Rotary Vane Vacuum Pump

Extruder Hydraulic Pump

Temperature Controlled Water Bath (Heat/Chiller)

Small or Consumable It tems Required inside the hot cell:

Grommet Pick

Piston Positioning Sleeve

Poly Bottle (1L)

Ring Positioner (H-2-821610)

Seal ( $H-2-821610)$

Spring Assembly (H-2-85449-7)

Universal Press Nut $(\mathrm{H}-2-85441-8)$

Wire/cable cutters

Wrench to remove quadralatch cap (H-2-690140-23)

$Q$ or $W$ canister, if desired

Sample vial $(20 \mathrm{~mL})$, if desired

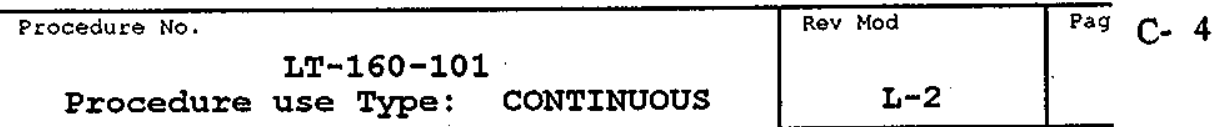




\subsection{PROCESS OVERVIEW}

The RGS Extraction System is designed to extract vapors from core samples of tank waste material: The extractor is temperature controlled and contains a mixing rotor for continued stirring of the sample during the entire processing session. The RGS sampler (which contains the sample material) is loaded into hot cell 1E-2, prepared, and mounted onto the RGS system in a vacuum tight configuration. The RGS system is then evacuated down to less than $10 \mathrm{~Pa}^{1}$. After system checks have been performed, the sampler valve is opened and the sample material is pushed (using the extruder system) into the extractor section of the RGS system.

A tube leads from the extractor, out of the hot cell, through a filter, and eventually to a liquid mercury positive displacement pump so that vapors can be pumped from the extractor to various (removable) vapor collection canisters for analysis elsewhere ${ }^{2}$.

\subsection{Physical Configuration}

Below are four schematic drawings of the RGS system. Figures 1 and 2 are line drawings that illustrate the general physical arrangement of the RGS system: Figure 1 shows the arrangement of sections outside the hot cell and figure 2 shows the arrangement of sections inside the hot cell.

Outside the hot cell is situated: the control cabinet, (which houses the instrumentation, collector side tube and fittings, auxiliary manifold, diluent reservoir, mercury positive displacement pump, data acquisition unit DACU, computer), heater/chilter unit, vacuum pumps (turbo-molecular and rotary vane), and the extruder hydraulic pump.

Inside the hot cell is situated the extruder device, the extractor and stirrer mechanism, and the secondary volume.

Figure 3 is a schenatic diagram of the system that shows, in closer detail, the configuration of the plumbing, instrumentation, and all valves located outside the hot cell.

Figure 4 is a schematic diagram (in similar detail) of the system components which are situated inside the hot cell including: the extractor, secondary volume, and associated manifold.

\begin{tabular}{|l|c|c|}
\hline Procedure No. & Rev Mod & Pal \\
Procedure use Type: ConTINUOUS & I-2 & \\
\hline
\end{tabular}


HNF-5443, rev. 0

9.0 PROCESS OVERVIEW (COntinued)

Figure 1: Overall RGS System Arrangement Outside Hot cell

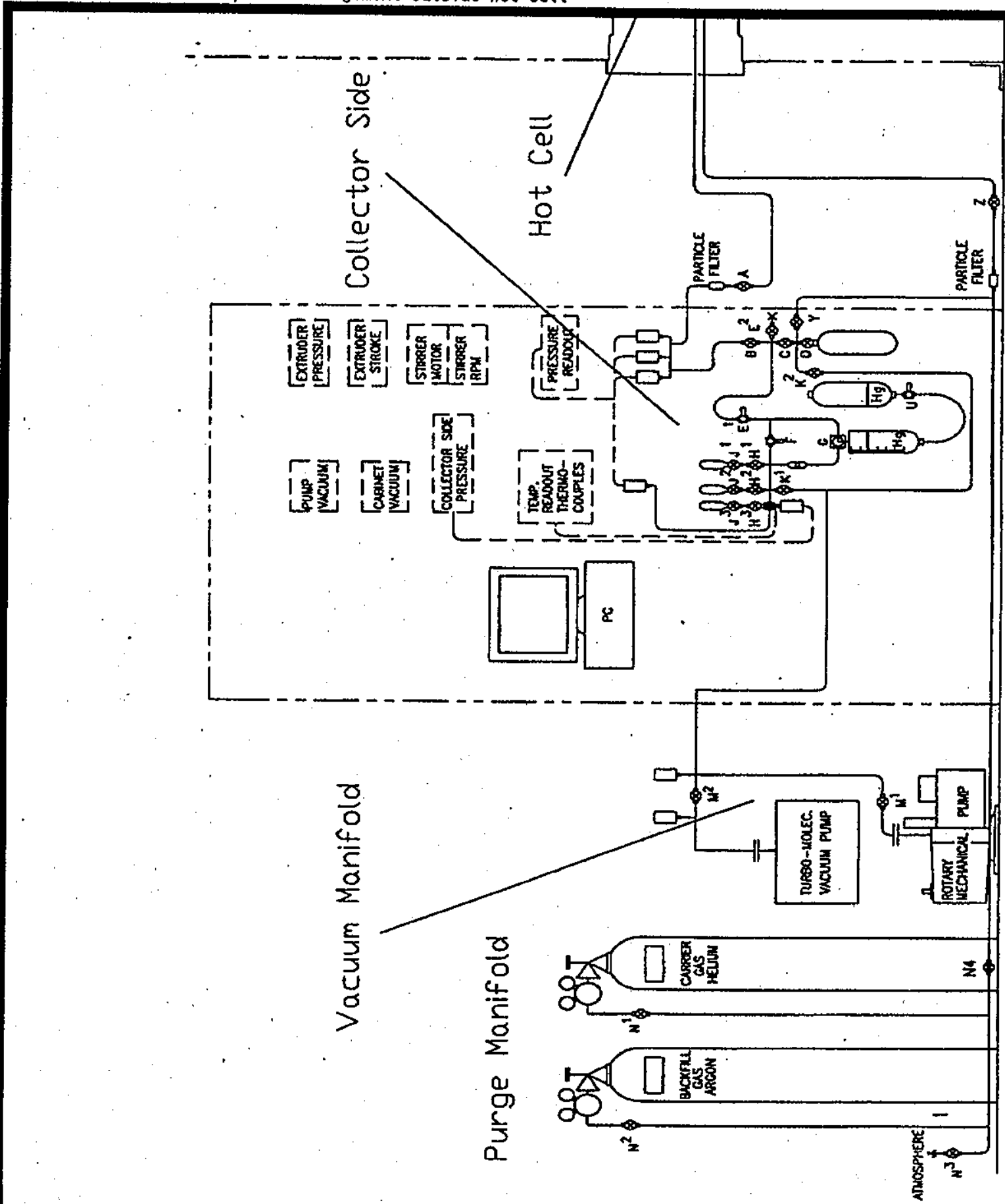

C- 6 
HNF-5443, rev. 0

9.0 PROCESS OVERVIEW (Continued)

Figure 2: Overall RGS System Arrangement Inside Hot Cell

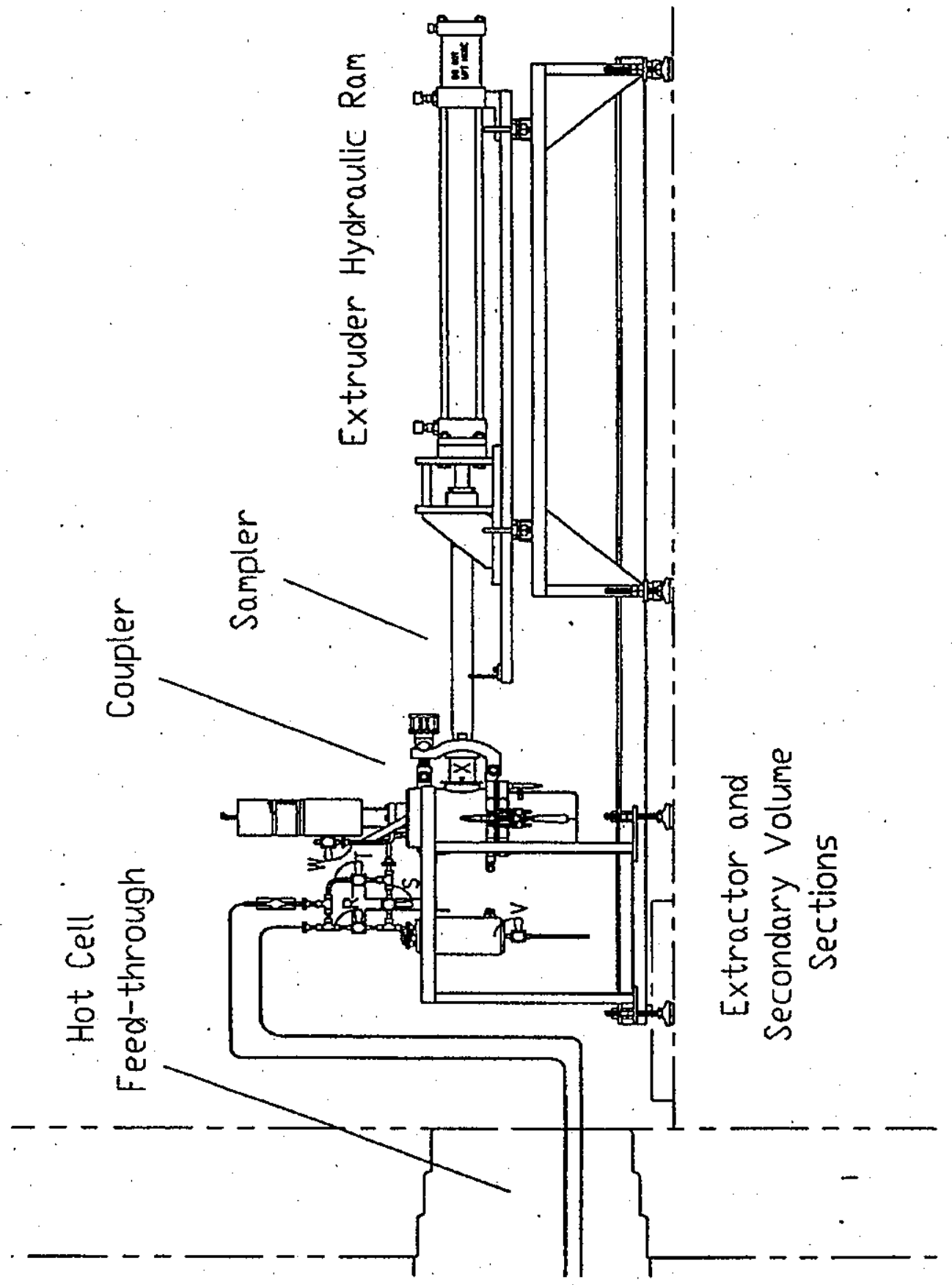

C- 7

\begin{tabular}{|l|l|l|l}
\cline { 2 - 3 } & $\begin{array}{l}\text { Procedure No. } \\
\text { Pev Mod } \\
\text { Procedure use Type: }\end{array}$ & $\begin{array}{c}\text { Pa! } \\
\text { L-2 ConTINUOUS }\end{array}$ & \\
\hline
\end{tabular}


HNF-5443, rev. 0

\subsection{PROCESS OVERVIEW (Continued)}

Figure 3: Detailed Schematic of RGS System Outside Hot Cell

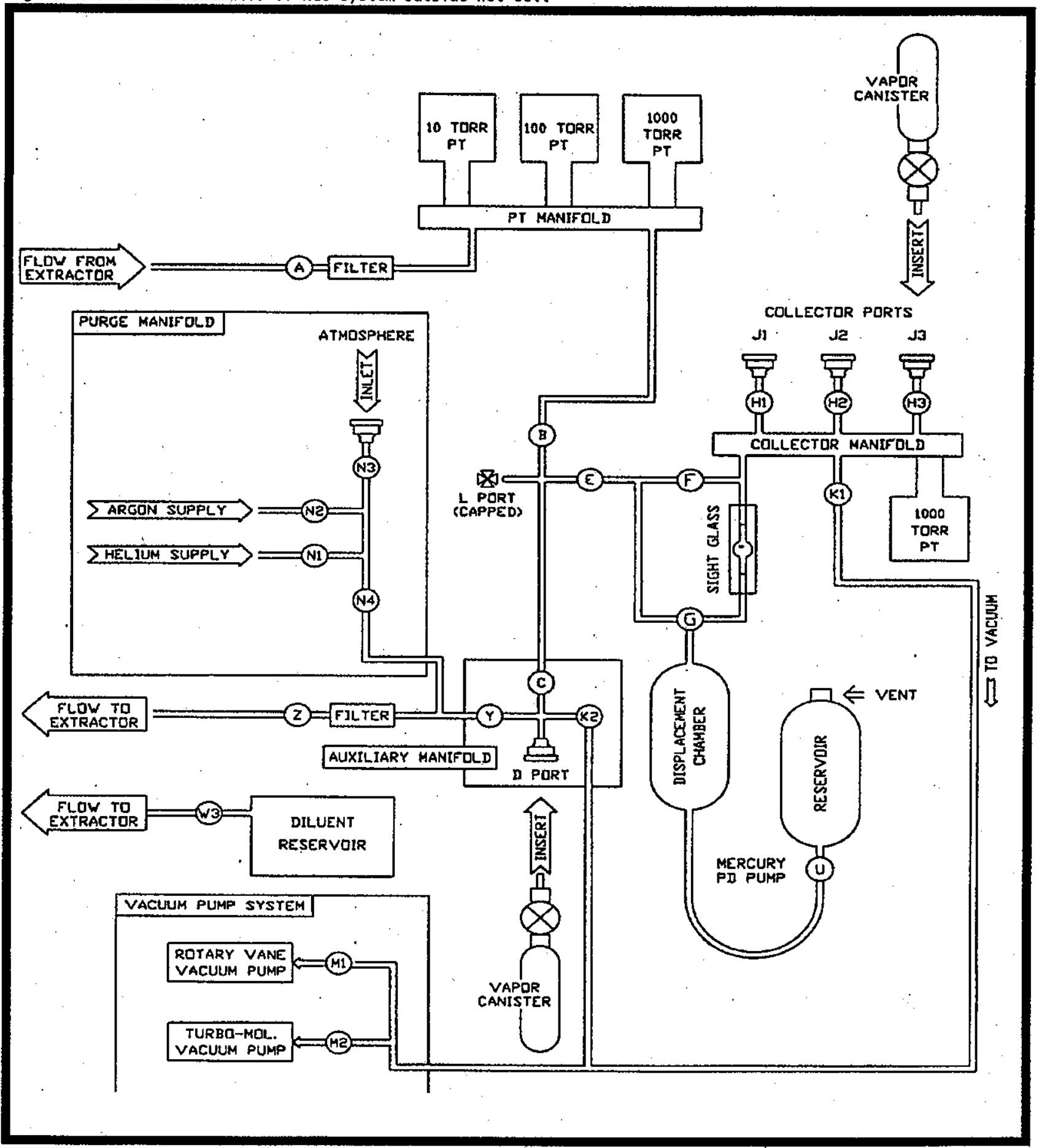

C- 8

\begin{tabular}{|l|l|l|}
\hline Procedure No. & Rev Mod & Pa \\
Procedure use Type: ContINUOUS & L-2 & \\
\hline
\end{tabular}


HNF-5443, rev. 0

\subsection{PROCESS OVERVIEW (Continued)}

Figure 4. Detailed Schematic of RGS System Inside Hot Cell

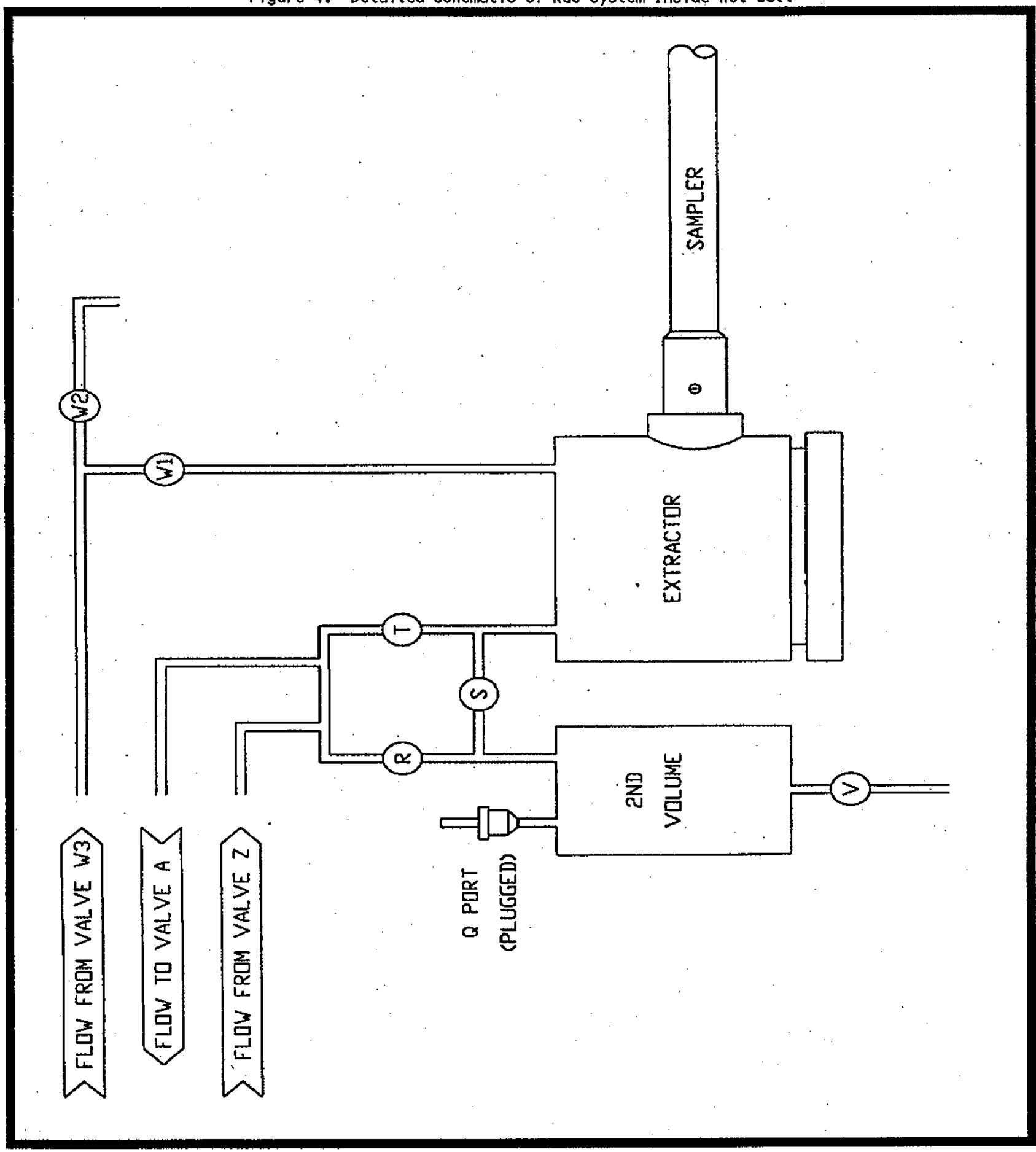


HNF-5443, rev. 0

\subsection{PROCESS OVERVIEW (Continued)}

\subsection{Section, Volume, and Valve Arrangement}

In order to draw quantitative conclusions from the pressure and temperature data acquired during the entire processing session, it is important to know the volumetric dimensions of the vapor containing sections of the RGS system. Therefore, volumetric capacities of the important sections of the RGS system are provided in Tables 1 and 2 below.

Table 1 lists the measured volumes for various fixed-volume sections of the RGS system. These volumes were measured by a combination of gravimetry (weighing water) and ideal gas law calculations.

Table 2 shows how the various sections are concatenated during various processing phases, e.g. bulk vapor extraction, exsolution, diluent addition, etc.

Also, a list of each valve is provided in Table 3 which describes how each valve is associated with the important sections of the RGS system and their function.

TABLE 1. SYSTEM SECTION VOLUME ASSIGNMENT

\begin{tabular}{|c|c|c|}
\hline Section & Description & Volume (cc) \\
\hline $\begin{array}{c}i \\
i i \\
i j i \\
i v \\
v \\
v i \\
v i i \\
v i i i \\
i x \\
\text { diluent } \\
\text { sample } \\
0 \\
\text { J1 } \\
\text { J2 } \\
\text { J3 }\end{array}$ & $\begin{array}{l}\text { Extractor to Valve } T \\
\text { Valve'T to Valves } B \text { and } Z \\
\text { Valve B to Valves } C, F, G \text { and Port L } \\
\text { Displacement Chamber and Sight Glass } \\
\text { Effective Hg Pump Displacement } \\
\text { Auxiliary Sample Manifold (between Valves C,D,K2,Y) } \\
\text { Collector Manifold (Valves F/G to H's, K1) } \\
\text { Canister Connector (e.g. Valve H to Canister Valve) } \\
\text { Secondary Volume } \\
\text { Volume of Added Diluent (mL) } \\
\text { Bulk Sample Volume Determination } \\
\text { Auxiliary Manifold Vapor Canister (Canister D) } \\
\text { Collection Canister J1 } \\
\text { Collection Canister J2 } \\
\text { Collection Canister J3 }\end{array}$ & $\begin{array}{l}1290 \\
262 \\
15 \\
464 \\
438 \\
10 \\
34 \\
2 \\
321 \\
300^{3} \\
B S V^{4} \\
D^{5} \\
\text { J1 } \\
\text { J2 } \\
\text { J3 }\end{array}$ \\
\hline
\end{tabular}


HNF-5443, rev. 0

\subsection{PROCESS OVERVIEW (Continued)}

TABLE 2. CONCATENATION OF TABLE 1 SECTIONS

\begin{tabular}{|c|c|}
\hline PROCESS PHASE & CONCATENATION \\
\hline $\begin{array}{l}\text { BULX VAPOR EXTRACTION } \\
\text { Extractor side (to Valve B) } \\
\text { Unpumped Vapor Sample Capture } \\
\text { Extractor side (to Valves F/G) } \\
\text { Collector side (filled Sight Glass). }\end{array}$ & $\begin{array}{l}i+i j-B S V D \\
i+i j+i i j+i v+v i i+(3 \bullet v i i i)+D+J 1+J 2+J 3-B S V D \\
i+i j+i i i+v i-B S V D \\
v i i+(3 \bullet v i i j)+J 1+J 2+J 3\end{array}$ \\
\hline $\begin{array}{l}\text { EXSOLUTION } \\
\text { Extractor } \\
\text { Collector side (to Valves } \mathrm{H1}, \mathrm{H2}, \mathrm{H3} \text { ) } \\
\text { Collector side (plus Canister Volumes) }\end{array}$ & $\begin{array}{l}i+i i+i i i+v i-B S V D \\
v i j \\
v i j+(3 \bullet v i i i)+J 1+J 2+\sqrt{ } 3\end{array}$ \\
\hline $\begin{array}{l}\text { EQUILIBRATED VAPOR EXTRACTION } \\
\text { EXtractor side } \\
\text { Collector side }\end{array}$ & $\begin{array}{l}i+i i+i i i+v i-B S V D \\
v i i+(3 \bullet v i i i)+J 1+J 2+J 3\end{array}$ \\
\hline
\end{tabular}

TABLE 3. VALVE AND PORT DESIGNATION AND FUNCTION

\begin{tabular}{|c|c|c|}
\hline $\begin{array}{l}\text { VALVE or } \\
\text { PORT }\end{array}$ & SEQUENCE & FUNCTION \\
\hline $\begin{array}{l}\text { Valve } A \\
\text { Valve } 8 \\
\text { Valve C }\end{array}$ & $\begin{array}{c}R, T, Z / A / B \\
A / B / C, E, L \\
B, E, L / C / D, K 2, Y\end{array}$ & $\begin{array}{l}\text { main sample line isolation valve } \\
\text { wet transducer isolation valve } \\
\text { auxiliary manifold isolation valve }\end{array}$ \\
\hline Port D & $C, X 2, Y / D$ & sample port where $D$ canister fits \\
\hline Valve D & Valve D/Port D & valve on the canister itself ( $D$ canister) \\
\hline $\begin{array}{l}\text { Valve } E \\
\text { Valve } F \\
\text { Valve } G\end{array}$ & $\begin{array}{c}B, C, L / E / F, G \\
E, G / F / G, H 1, H 2, H 3 \\
E, F / G / U / G / F, H 1, H 2, H 3\end{array}$ & $\begin{array}{l}\text { mercury pump isolation valve } \\
\text { mercury pump bypass valve } \\
\text { mercury pump 3-way valve }\end{array}$ \\
\hline $\begin{array}{l}\text { Valve } H 1 \\
\text { Vatve } H 2 \\
\text { Valve } H 3\end{array}$ & $\begin{array}{l}F, G, H 2, H 3 / H 1 / \text { Port } J 1 \\
F, G, H 1, H 3 / H 2 / \text { Port } J 2 \\
F, G, H 1, H 2 / H 3 / \text { Port } J 3\end{array}$ & $\begin{array}{l}\text { sample port } J 1 \text { isolation valve } \\
\text { sample port } \mathrm{J} 2 \text { isolation valve } \\
\text { sample port } \mathrm{J3} \text { isolation valve }\end{array}$ \\
\hline I & & no valve or port designated with this letter \\
\hline $\begin{array}{l}\text { Port } \sqrt{1} \\
\text { Port J2 } \\
\text { Port J3 }\end{array}$ & $\begin{array}{l}\text { H1/Port } \mathrm{J1} \\
\text { H2/Port j2 } \\
\text { H3/Port } \mathrm{J3} \\
\end{array}$ & $\begin{array}{l}\text { sample port where vapor canister fits } \\
\text { sample port where vapor canister fits } \\
\text { sample port where vapor canister fits }\end{array}$ \\
\hline $\begin{array}{l}\text { Valve } \mathrm{J1} \\
\text { Valve } \mathrm{j2} \\
\text { Valve } \mathrm{J3}\end{array}$ & $\begin{array}{l}\text { Vatve J1/Port } \mathrm{J1} \\
\text { Valve } \mathrm{J} 2 / \text { Port } \mathrm{J} 2 \\
\text { Valve } \mathrm{J3} / \text { Port } \mathrm{J3}\end{array}$ & $\begin{array}{l}\text { vatve on the canister itself (J canister) valve on the } \\
\text { canister itself ( } \mathrm{J} \text { canister) } \\
\text { valve on the canister itself ( } \mathrm{J} \text { canister) }\end{array}$ \\
\hline $\begin{array}{l}\text { Valve K1 } \\
\text { Valve } K 2\end{array}$ & $\begin{array}{c}\mathrm{F}, \mathrm{G}, \mathrm{HT}, \mathrm{H2}, \mathrm{H3} / \mathrm{K1} / \mathrm{M1}, \mathrm{ML} \\
\mathrm{C}, \mathrm{D}, \mathrm{Y} / \mathrm{KL} / \mathrm{M1}, \mathrm{ML}\end{array}$ & $\begin{array}{l}\text { system main vacuum isolation valve } \\
\text { auxiliary manifold vacuum isolation valve }\end{array}$ \\
\hline Port $L$ & $B, C, E / L$ & sample port (non-purgeable) \\
\hline $\begin{array}{l}\text { Valve } M 1 \\
\text { Valve } M 2\end{array}$ & $\begin{array}{l}\mathrm{K} 1, \mathrm{~K} 2, \mathrm{M} 2 / \mathrm{M1} / \mathrm{pump} \\
\mathrm{K} 1, \mathrm{~K} 2, \mathrm{M} 1 / \mathrm{M} 2 / \text { pump }\end{array}$ & $\begin{array}{l}\text { rotary vane vacuum pump isolation valve } \\
\text { turbo-mol. vacuum pump isolation valve }\end{array}$ \\
\hline $\begin{array}{l}\text { Valve N1 } \\
\text { Valve N2 } \\
\text { Valve N3 } \\
\text { Valve N4 }\end{array}$ & $\begin{array}{c}\text { regulator/N1/N2,N3,N4 } \\
\text { regulator/N2/N1,N3,N4 } \\
\text { Port } N / N 3 / N 1, N 2, N 4 \\
Y, Z / N 4 / N 1, N 2, N 3\end{array}$ & $\begin{array}{l}\text { helium supply isolation valve } \\
\text { argon supply isolation valve } \\
\text { isolation valve (used for air inlet) } \\
\text { purge manifold isolation valve }\end{array}$ \\
\hline $\begin{array}{l}\mathrm{O} \\
\mathrm{P}\end{array}$ & & $\begin{array}{l}\text { no valve or port with thís letter } \\
\text { obsolete } P Q \text { canister valve }\end{array}$ \\
\hline $\begin{array}{l}\text { Valve } Q \\
\text { Valve } R \\
\text { Valve } S \\
\text { Valve T }\end{array}$ & $\begin{array}{l}\text { Q/2nd-volume } \\
\text { 2nd-volume, S/R/A,T,Z } \\
\text { extr., T/S/2-vol, R } \\
\text { extr., S/T/A,R,Z }\end{array}$ & $\begin{array}{l}\text { 2nd volume port (no valve present) } \\
\text { 2nd volume isolation valve } \\
\text { 2nd volume/extractor bypass valve } \\
\text { extractor isolation valve }\end{array}$ \\
\hline $\begin{array}{l}\text { Valve U } \\
\text { Valve V }\end{array}$ & $\begin{array}{l}\text { G/U/Hg Reservoir 2- } \\
\text { Vol/V/outlet port }\end{array}$ & $\begin{array}{l}\text { Tiquid mercury cut-off valve } \\
\text { 2nd volume port to (beaker) valve }\end{array}$ \\
\hline Port $W$ & extractor port & extractor liquid addition port \\
\hline $\begin{array}{l}\text { Valve W1 } \\
\text { Valve W2 } \\
\text { Valve W3 }\end{array}$ & $\begin{array}{c}\text { extr/w1/W2, W3 } \\
\text { W1/W2/W3 } \\
\text { Diluent Reservoir/W3 }\end{array}$ & $\begin{array}{l}\text { extractor liquid addition valve } \\
\text { liquid addition purge valve } \\
\text { Diluent supply shut-off valve }\end{array}$ \\
\hline Vatve X & sampler:x/extractor & sampler valve itself \\
\hline $\begin{array}{l}\text { Vatve Y } \\
\text { Valve } Z\end{array}$ & $\begin{array}{l}\mathrm{N} 4, \mathrm{Z} / \mathrm{Y} / \mathrm{C}, \mathrm{D}, \mathrm{K} 2 \\
\mathrm{R}, \mathrm{T} / \mathrm{Z} / \mathrm{N} 1, \mathrm{~N} 2, \mathrm{~N} 3\end{array}$ & $\begin{array}{l}\text { aux. manifold purge-gas isolation valve } \\
\text { main purge line isolation valve }\end{array}$ \\
\hline
\end{tabular}

\subsection{Description of Process}

9.3.1 Phase I, Extrusion and Bulk Vapor Extraction

\begin{tabular}{|l|l|l|l|}
\hline $\begin{array}{l}\text { Procedure No. } \\
\text { LT-160-101 }\end{array}$ & $\begin{array}{l}\text { Par Mod } \\
\text { Procedure use Type: CONTINUOUS }\end{array}$ \\
\hline
\end{tabular}




\subsection{PROCESS OVERVIEW (Continued)}

After the evacuation, preliminary leak rate and instrument offset determinations have been performed, preparations need to be made to begin sample processing. The first phase in the processing scheme involves extrusion of the sample and extraction of the unbound vapors (called bulk vapors). These preparations include:

- re-acquisition of preliminary vacuum, 10 Pa or less

- extractor cooled to $10^{\circ} \mathrm{C}$

- automatic data acquisition initiated and saving to file

- stirrer turning at $3 \mathrm{rpm}$ (mixer speed)

- secondary volume and vacuum pumps isolated

C- 12

$\begin{aligned} & \text { Procedure No. } \\ & \text { LT-160-101 }\end{aligned}$
Procedure use Type: ConTINUOUS


After these preparations have been completed and the desired situations exist, the sampler valve is opened and the sample material is extruded into the extractor ${ }^{6}$.

Once the sample material is fully transferred from the sampler to the extractor (via actuation of the hydraulic extruder), a short pause in processing activity is made to allow the newly expanded vapors to equilibrate with the surroundings and achieve thermal equilibrium. It is assumed that the sudden expansion of the sample material into the evacuated volume of the extractor (and associated tubing), the shear stress of the sample during the extrusion, and the continued stirring of the sample in the extractor provides sufficient agitation to free the majority of the retained gas from the bulk of the sample. Thus, temperature and pressure measurements should be continually monitored through automatic data logging and manual recording in the process log.

The initial pressure of the vapor is the first number that should be recorded under "Bulk Vapor Extraction" in the process log (Appendix A contains a sample of a process log data sheet). This is the pressure of the vapor (after achieving thermal equilibrium) in the concatenated sections of the system from the extractor to valve $B$ (closed). Table 1 lists the volumes of the concatenated sections of the system for each phase of the process.

The first vapor sample to be acquired is captured without pumping the retained gas and is collected in "Canister. D" at the auxiliary $\left(q . v .^{?}\right)$ manifold. These vapors are acquired when valve $B$ is opened and the vapor is allowed to fill the system up to valves $F$ and $G$. Collection of the sample material in this first vapor sample capture routine occurs only as a result of allowing the vapors of the sample to fill the evacuated sections of the RGS system and the collection canister as certain valves are opened. This vapor sample contains the minimum concentration of condensable vapor components. This is to say, that the mole fractions of individual gas species are least biased in the concentrations of ammonia, water vapor, and possibly even nitrous oxide. Thus, this first sample probably represents the truest proportions of gas species that are. actually present as gases in the sample.

After a portion of this "unpumped" vapor is isolated for analysis (by closing the valve of the D canister which is located at the auxiliary manifold), pumping of the extractor should commence right away in a series of thirteen pump cycles to fili the collection canisters, fitted onto the collector side manifold. The mechanism by which these extraction pump cycles are performed is simple positive displacement using liquid mercury as the volume displacement medium and a threeway valve to direct the flow. In this way, vapor is pumped from a low pressure $(1-5 \mathrm{kPa})$ extractor side to a high pressure ( $>5 \mathrm{kPa}$ ) collector side by allowing a column of (iquid mercury to repeatedly $r i s e$ and fall within the confines of a cylindrical displacement chamber, approximately $440 \mathrm{~mL}$ in capacity. Vapor is allowed into and out of the displacement chamber by cycling a three-way valve back and forth between the collector and extractor sides of the displacement pump in concert with the rise and fall of the column of mercury (about $500 \mathrm{~mL}$ ). The collected vapor is subsequently analyzed quantitatively for gas species composition. Usually, on the collector side of the pump, there are three individual collection canisters ${ }^{8}$ connected to the collector manifold.

It was decided that thirteen extraction cycles was sufficient for the complete transfer and collection of the retained gas from the extractor to the collector because this would, theoretically, transfer at least $96 \%$ of the total amount of vapor in the extractor to the collector, regardless of the initial extractor pressure. There was the concern that the "representativity" of the collected vapors would diminish, however, as a result of too much pumping since the collected vapors would become more and more biased with ammonia and water vapor which exsolute from the sample with every pump. Development exercises has shown that thirteen (13) pump cycles was an appropriate balance between too little and too much pumping.

Throughout the thirteen extraction cycles, the pressure and temperature of both the extractor and collector sides of the RGS system are recorded. In doing this, a profile of the temperature and pressure is obtained which may also provide a qualitative profile of this sample material's retained gas characteristics in so far as its "free releasable" (i.e. non-dissolved) retained gas properties.

The system's valve and physical configuration for this "Bulk Vapor Extraction" session is as follows:

a. Secondary volume (q.v.) is isolated from the extractor manifold.

b. Extractor manifold consists of the extractor main volume and all lines running from valve $Z$ (closed) to valve $F$ (closed) and valve $G$ (turned to the collector side). vatve $C$ to the auxiliary vapor sample manifold is open but valve $D$ (vapor sample canister) is closed before the 13 pump extraction routine begins.

c. During the extraction pumping, valves $\mathrm{H1}, \mathrm{HZ}$, and $\mathrm{H3}$ are open on the collector manifold as are valves $\mathrm{J} 1, \mathrm{~J} 2$, and $\mathrm{J} 3$ on the vapor sample canisters.

d. The extractor is maintained at about $10^{\circ} \mathrm{C}$. The rest of the RGS system is subject to ambient room temperature (usually about $25^{\circ} \mathrm{C}$ ).

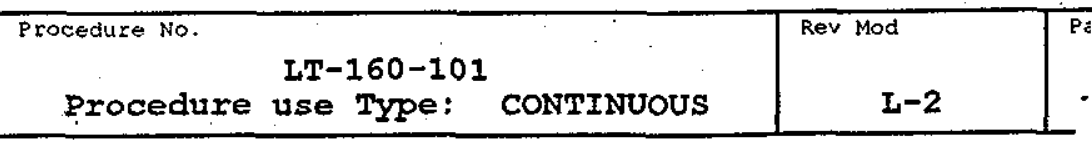




\subsection{PROCESS OVERVIEW (Continued)}

e. The stirrer turns at $3 \mathrm{rpm}$ (mixer speed).

9.3.2 Phase II, Exsolution

After the thirteen-cycle extraction process is completed, an exsolution profile is generated by monitoring the system's pressure during an additional nineteen (19) extraction cycles. The purpose of generating an exsolution profile is to determine whether the amount of vapors which exsolute from the sample material during each pump cycle can be quantitatively characterized. This quantitative character could then be applied to the results of the bulk vapor extraction (first 13 cycles) as a correction for acquiring the actual quantity of retained gas from the apparent quantity which was actually determined ${ }^{10}$.

To generate the exsolution profile, vapor is pumped from the extractor to the collector while the pressure and temperature of the extractor and collector sides is recorded. The vapor in the collector side is then discarded (in some cases a portion is saved first) and then the mercury pump (through the collector manifold) is purged of any condensed vapor by exhaustively evacuating the section down to at least $10 \mathrm{~Pa}$, before executing another cycle.

The reason for this exhaustive evacuation is to prevent any accumulated condensed vapors from reevaporating inside the pump chamber, flowing back into the extractor and thus reducing the effectiveness of the pump. Without doing this the "evacuated" pump chamber would be comparable in pressure to the extractor side pressure due to re-vaporization and so very little mass transfer would occur between the extractor and the pump.

During the exsolution profile, portions of the vapor is saved for analysis. A total of nine (9) vapor samples are acquired: three from the first, tenth, and nineteenth extraction cycle. Each of these vapor samples is contained in an individual canister so the proportions of gas species could be examined as a function of the extraction sequence, in triplicate.

The system's vatve and physical configuration for this part of the test is as follows:

a. Secondary volume is isolated from the extractor manifold as before.

b. Extractor manifold consists of the extractor main volume and all tines running from valve $Z$ (closed) to valve $F$ (closed) and valve $G$ (turned to the collector side). Also, port $D$ of the auxiliary manifold is plugged.

c. After each vapor collection, to minimize the back flow of residual vapors from the previous extraction cycle, the collector-side manifold and the mercury displacement chamber is evacuated to less than $10 \mathrm{~Pa}$ prior to performing the next cycle.

d. During each extraction cycle, the extracted vapors are pumped with the mercury pump to the collector side manifold while the $\mathrm{H}$ valves are all closed. At the end of the ist, 10 th, and 19 cycles, all the $H$ valves are opened and the pressure of the collector manifold is further reduced as the three collection canisters are filled. This subsequent pressure transition is also recorded.

e. The extractor is maintained at about $10^{\circ} \mathrm{C}$. The rest of the RGS system is subject to ambient room temperature (about $25^{\circ} \mathrm{C}$ ).

f. The stirrer turns at 3 rpm (mixer speed).

9.3.3 Phase III, Standard Diluent Addition, Equilibration, and Vapor. Extraction

Ammonia vapor is commonly found as a significant component in retained gas. However, due to its high solubility in aqueous media, and because of its affinity for metallic surfaces, it is difficult to obtain quantitative determinations of ammonia as a vapor in this particular mass transport system. As an attempt to compensate for these complications, an addition of $300 \mathrm{~mL}$. diluent consisting of approximately $0.04 \mathrm{M}{ }^{15} \mathrm{NH}_{4} \mathrm{OH}$ is added directly to the sample in the extractor (after the bulk vapor extractions and exsolution profile extractions are completed) to function as an internal standard for total ammonia concentration determination in the sample material.

After diluent addition, the diluted sample is atlowed to come to equilibrium while being stirred at $3 \mathrm{rpm}$ (mixer speed) for at least 96 hours; after which a set of three vapor samples is acquired (simultaneously) for isotopic mass ratio analysis. The specific analysis to be conducted is the isotope ratio determination (IRD) of the ratio of the concentrations of ${ }^{15} \mathrm{NH}_{3}$ to ${ }^{14} \mathrm{NH}_{3}$ by way of quantitative mass analysis using ultra-sensitive gas phase mass spectrometry. With

Procedure No.
IT-160-101
Procedure use Type:




\subsection{PROCESS OVERVIEW (Continued)}

this determination it is thought that the original concentration of ammonia in the sample can be determined by using the equation:

$$
\frac{\left[{ }^{15} \mathrm{NH}_{3}\right]}{\left[\mathrm{NH}_{3}\right]}=\frac{\text { IRD }}{1+\text { IRD }}
$$

Where:

$$
\begin{aligned}
& {\left[{ }^{25} \mathrm{NH}_{3}\right]=\text { concentration of labeled ammonia }} \\
& {\left[\mathrm{NH}_{3}\right]=\text { total ammonia concentration }} \\
& \text { IRD }=\left[{ }^{25} \mathrm{NH}_{3}\right] /\left[^{14} \mathrm{NH}_{3}\right] \text { isotopic ratio determination }
\end{aligned}
$$

Thus, the original amount of $\mathrm{NH}_{3}$ in the sample can be determined by plugging in the values for $\left[{ }^{15} \mathrm{NH}_{3}\right.$ ] (the concentration of labeled ammonia in the diluted sample) and using the IRD results and solving for $\left[\mathrm{NH}_{3}\right]$. Inaccuracy with this technique might be that the true concentration of ${ }^{15} \mathrm{NH}_{3}$ (diluent plus sample) is not accurately known since the diluted sample is still a heterogeneous mixture (non-solution).

The temperature of the extractor is maintained at about $10^{\circ} \mathrm{C}$ during the addition of the diluent and the mixture is stirred at $3 \mathrm{rpm}$ (mixer speed) for the duration of the equilibrium interim and during the vapor extraction exercise. The vapor sample canisters are filled simultaneousty in order to replicate vapor samples for analysis in triplicate.

Usually, no attempt is made to de-gas the diluent, however, so it is expected that air components (nitrogen, oxygen, argon) should be detected in these subsequent vapor sample acquisitions if analyzed for such species. No effort is made to degas the diluent prior to its use though since the primary objective of this effort is to determine the resultant ratio of the concentration of ${ }^{23} \mathrm{NH}_{3}$ to ${ }^{14} \mathrm{NH}_{3}$ and this determination should be unaffected by the presence of other "spectator" gas species.

The system's valve configuration for the addition of the diluent and the equilibration interim:

a. The extractor is isolated from the rest of the system by closing valve $T$.

b. The heater/chiller unit is turned off.

c. Diluent is added to the extractor through valve W1.

d. The extractor contents are stirred at $3 \mathrm{rpm}$ (mixer speed) for at least 96 hours.

e. The rest of the RGS system is open to the mechanical vacuum pumps for exhaustive evacuation.

The addition of the diluent to the extractor is performed as follows:

a. The diluent supply line is flushed with approximately $100 \mathrm{~mL}$ of the diluent solution to purge the lines of "old" diluent and fill with "new" dilluent.

b. $\quad 300 \mathrm{~mL}$ of diluent is added directly to the extractor through valve W1. Since valve $T$ is closed, the pressure transducers are blind to this operation. Residual vacuum in the extractor is sufficient to draw the entire $300 \mathrm{~mL}$ aliquot of diluent. into the extractor through valve $W 1$.

c. Extractor temperature is not controlled but the stirrer continues to rotate at $3 \mathrm{rpm}$ (mixer speed).

After 96 hours of equilibration interim, the extractor vapors are pumped to the collector side manifold in the same fashion as the bulk vapor was pumped.

The system's valve configuration for the vapor extraction exercise of the equilibrated vapors is as follows:

a.: Secondary volume is isolated from the extractor manifold.

b. Extractor manifold consists of the extractor main volume and all lines running from valve $Z$ (closed) to valve $F$ (closed) and valve $G$ (turned to the collector side). Also, port $D$ of the auxiliary manifold is plugged.

c. The extractor is being stirred at $3 \mathrm{rpm}$ (mixer speed).

$\begin{aligned} & \text { Procedure No. } \\ & \text { IT-160-101 }\end{aligned}$
Procedure use Type: contrnuous




\section{9:0 PROCESS OVERVIEW (Continued)}

\subsubsection{Phase IV, Butk Sample Volume Determination}

After the sample materiat is thoroughly exhausted of freely releasable vapors through the butk vapor extraction, exsolution profile, and equilibrated vapor extractions, it is then possible to conduct the "Butk Sample Volume Determination" which necessarily involves the addition of air to the extractor. Air (at ambient pressure) is used because contamination of the sample material wi th air components is no longer a concern and there is no danger of possibly over pressurizing the RGS system such as could happen if bottled gases such as argon or helium were used. The bulk sample volume determination procedure is followed three times for a triplicate determination.

Three main steps must be performed in this experiment:

a. An initial low pressure $(\sim 4 \mathrm{kPa})$ measurement of the extractor is recorded and then the extractor is isolated from the rest of the system. The volume of the empty extractor is already known.

b. Another section of the RGS system is exposed to the atmosphere and allowed to completely fill to ambient atmospheric pressure $(\sim 100 \mathrm{kPa})$. The volume of this section is also al ready known.

c. Finally, the extractor section is valved in to this second "pressurized" section (after it is isolated from the atmosphere) and the two volumes allowed to equilibrate to a final resultant pressure (somewhere in mid range) and this third pressure measurement is recorded.

The three pressure readings (and associated volumes) can then be applied to Equation $2 a$ (which is derived from the equation for an ideal gas) in order to 1) determine the volume of the diluted sample for use in Equation 1 for the determination of the concentration of ammonia in the sample, and 2) for use in Equation $2 \mathrm{~b}$ to determine the volume of the sample material itself.

$$
\begin{gathered}
D=E-A \cdot \frac{\left(P_{3}-P_{2}\right)}{\left(P_{1}-P_{3}\right)} \\
V=D-S
\end{gathered}
$$

Where:

$$
\begin{aligned}
& A=\text { volume of the Air let into the filled section } \\
& D=\text { volume of the Diluted sample material } \\
& E=\text { volume of the Extractor vessel (when empty) } \\
& P_{1}=\text { initial pressure of the extractor } \\
& P_{2}=\text { pressure of the al iquot of air } \\
& P_{3}=\text { resultant pressure of the equilibrated system } \\
& S=\text { volume of the Standard di luent added } \\
& V=\text { volume of the Bulk sample (unknown) }
\end{aligned}
$$

\subsection{PROCEDURE STEPS (Continued) NOTE: This is the end of the Procedure Steps.}

IT-160-101

Procedure use Type:
Rev Mod

CONTINUOUS 
HNF-5443, rev. 0

9.0 PROCESS OVERVIEW (Continued)

$\checkmark$

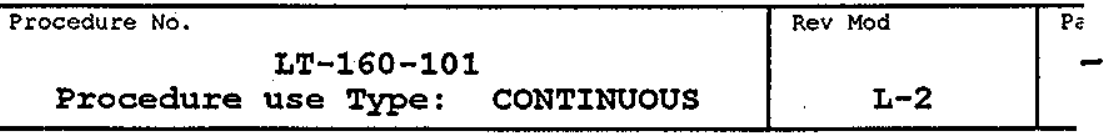




\subsection{PROCEDURE STEPS}

NOTE: Sections, or steps within sections, of this procedure may be performed out of sequence, as required.

10.1 Sampler Preparation and Pre-Start Configuration Verification

10.1.1 Sampler Preparation

1. Cut the valve closing cables.

2. Remove the quadralatch cap and mousetrap assembly from the sampler ${ }^{11}$.

NOTE: The mouse trap assembly includes all the following parts:

Pull Block
Spring
stop
Plunger
Release Disk
Retainer Ring

(H-2-85097-11)

$(H-2-85097-46)$

$(\mathrm{H}-2-85097-25)$

$(\mathrm{H}-2-821608-24)$

$(H-2-821608-41)$

3. Slide the ring positioner over the threaded end of the sampler.

4. Insert the piston positioning sleeve into the sampler.

5. Install the universal press nut on the threaded side of the sampler..

6. Remove the tape and spring stops (two) from the sampler.

7. Install the spring assembly through the back of the universal press nut.

8. Ptace the seal in the extractor sample port or on the valve end of the sampler.

9. Notify the duty shift operations manager before using water which will wash down the hot cell drains.

10. Wash (with water) and dry the vatve end of the sampler.

11. Mount the sampler on the extruder and couple it to the extractor.

12. Use the gromet pick to remove the gromet covering the valve opening screw.

10.1.2 Instrument Conditions

1. Ensure rotary vane pump is running and valve $M 1$ is open.

2. Ensure valve $M 2$ (to turbo-molecular vacuum pump) is closed.

3. Ensure all pressure indicator panels are operating.

4. Ensure mercury reservoir is at bottom of travel.

10.1.3 Port and Valve Configuration

1. Ensure sampler is mounted onto the extractor and its valve is closed.

2. Ensure vapor canisters are installed at the "H" ports and at the auxiliary port"

3. Ensure the following vatve configurations: CLOSED: $\{M 2, N(1,2,3), 5, U, W(1,2,3)\} ;$ OPEN: $(A, B, C, D, E, F, G \text { (to collector), } H(1,2,3), J(1,2,3), K(1,2), M 1, N 4, R, T, Y, Z\}^{13}$.

4. Ensure port $Q$ is plugged.

5. Ensure system is evacuated to less than $0.01 \mathrm{kPa}$.

10.1.4 Start-Up Sequence

1. Ensure RGS software is running and DACU is operating.

2. Ensure stepper motor controllers are on.

3. Raise mercury reservoir to the 0-point.

4. Raise mercury column to $3 / 4$-point (by opening valve U).

5. Lower mercury reservoir to bottom and Ensure mercury column is falling.

\begin{tabular}{|l|r|r|}
\hline Procedure No. & Rev Mod & Pa \\
Procedure use Type: ConTINUOUS & I-2 & . \\
\hline
\end{tabular}


HNF-5443, rev. 0

6. Ensure pressure readings are indicating reasonable values.

C- 19

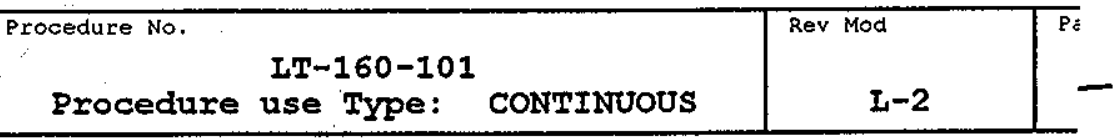




\subsection{Processing Sequences}

\subsubsection{Leak Rate Determination}

1. Record core sample identification in notebook or process log sheet.

2. Set automatic data acquisition to 10 -second interval data log and record data file name in notebook.

3. Close valves: $K(1,2), N 4, Y, Z$.

4. Continue to acquire and $\log$ data to file for about 30 minutes.

5. Stop data acquisition, close file, and copy data file to floppy disk.

6. Compute system's leak rate as millimoles per second.

NOTE: Leak rate may be computed as:

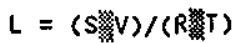

$$
\begin{aligned}
& \text { Where: } \quad L=\text { leak rate }(M \mathrm{~mol} / \mathrm{sec}) \\
& S=\text { slope of pressure/time curve (kPa/sec) } \\
& V=\text { system volume (2700 cc, conservative) }
\end{aligned}
$$

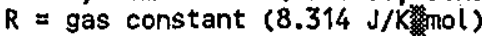

$$
\begin{aligned}
& T=\text { temperature }(K)
\end{aligned}
$$

7. If leak rate is less than $3 \times 10^{-6} \mathrm{mmol} / \mathrm{sec}$ then continue; otherwise correct leak rate problem.

8. Record leak rate determination in notebook.

10.2.2 Pressure Transducer Full-scale Zero offset Check

1. Record the calibration date for all pressure transducers and the DACU instrument in the notebook.

2. Ensure the following valve configurations: CLOSED: $\{K(1,2), M 2, N(1,2,3,4), S, U, V$, $W(1,2,3), X, Y, Z\} ; \operatorname{OPEN}:(A, B, C, D, E, F, G(\operatorname{collector}), H(1,2,3), J(1,2,3), M 1, R, T\}$.

3. Set automatic data acquisition to 10 -second interval data log and record data file name in notebook.

4. Open vatves $N 3, N 4$, and $Z$, wait about 5 seconds then close valve N3.

5. Wait for system's temperature and pressure to stabilize and then record pressure indications in notebook as "High pressure indication."

6. Reduce pressure to $\sim 10 \mathrm{kPa}$ by controlling vacuum with valve $\mathrm{K} 1$.

7. Wait for system's temperature and pressure to stabilize and then record pressure indications in notebook as "Medium pressure indication."

8. Reduce pressure to $\approx 1 \mathrm{KPa}$ (controlling with valve $\mathrm{K} 1$ ).

9. Wait for system's temperature and pressure to stabilize and then record pressure indications in notebook as "Low pressure indication."

10. Stop data acquisition, close file, and copy data file to floppy disk.

11. Open valve $\mathrm{K} 1$ and allow system's pressure to continue to reduce to less than $0.01 \mathrm{kPa}$.

10.2.3 Sample Extrusion and Bulk Vapor Extraction

1. Ensure heater/chiller unit is controlling to $10^{\circ} \mathrm{C}$ and extractor temperature $\sim 10{ }^{\circ} \mathrm{C}$.

2. Turn on stirrer motor to $60 \mathrm{rpm}$.

3. Ensure system pressure less than $0.01 \mathrm{kPa}$.

4. Close valves: $N 4, K(1,2), Y$, and $Z$.

5. Ensure the following valve configurations: CLOSED: $\{K(1,2), M 2, N(1,2,3,4), U, W(1,2,3)$, $X, Y, Z\} ;$ OPEN: $\{A, B, C, D, E, F, G$ (to collector), $H(1,2,3), J(1,2,3), M\{, R, T\}$.

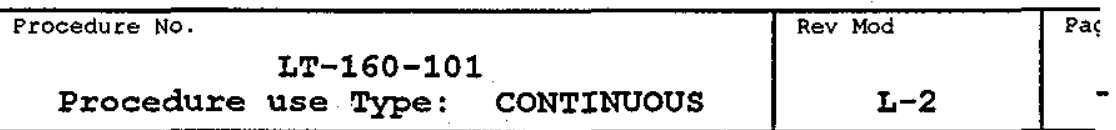




\section{HNF-5443, IeV.O}

6. Set automatic data acquisition to 10 -second interval data log and record data file name in notebook.

7. Adjust pressure indicator zero offsets as necessary.

8. Close valves $R$ and $B$.

9. Remove rubber gromet from sample valve.

10. Open sampler valve Sivalve $x)$.

11. Extrude sample material into extractor.

12. Wait until system temperature and pressure stabilizes and then record: date, time, event, temperature, pressure in notebook.

13. Open valve $B$ and wait for system's temperature and pressure to stabilize.

14. Record: date, time, event, temperature, pressure in notebook.

15. Close valve D and record: sample/container ID, temperature, and pressure in notebook.

16. Close valve F. .

17. Perform the following steps twelve (12) tïmes.

a. Raise the mercuryoservair above the 0 point

a open vatve und antrol the flow of mercury to sight glass with valve $G$ and height of reservofir

c. Lower mercury reservoir to bottom of travel.

d. Record the system's temperature and pressure in notebook.

e. Turn valive $G$ to extractor side.

f. Wait until mercury completely evạcuates displacement bulb.

g. close valve $U$.

h. Turn valve $G$ to collector side.

i. Check off completed cycle number:

\begin{tabular}{|c|c|c|c|c|c|}
\hline 1 & 2 & 3 & 4 & 5 \\
\hline 7 & 8 & 9 & 10 & 19 & 19 \\
\hline
\end{tabular}

18. Raise mercury reservoir above 0-point.

19. Open valve $U$ and control the flow of mercury to sight glass with valve $G$ and height of reservoir:

20. Lower mercury reservoir to bottom of travel.

21. Record temperature and pressure in notebook.

22. Close valves $J(1,2,3)$ and $H(1,2,3)$ and record vapor sample/canister 10 , temperature, and pressure in notebook.

23. Stop data acquisition, close file, and copy data file to floppy disk.

24. close valve B.

25. Remove the vapor canisters from the RGS system.

26. Survey each vapor canister by swabbing in and around the connector tube and then surveying the swab for removable radioactive contamination.

27. Place three new canisters (with $\mathrm{J}$ valves open) at $H$ ports and plug auxiliary porț.

28. Open valves $H(1,2,3)$.

29. Turn valve $G$ to collector side.

30. Ensure the following valve configurations: CLOSED: $C B, K 2, M 2, N(1,2,3,4), R, S, U, V$, $W(1,2,3), Y, Z)$; OPEN: $(A, C, E, F, G$ (to collector), $H(1,2 ; 3), J(1,2,3), K 1, M 1$, $T$ ).

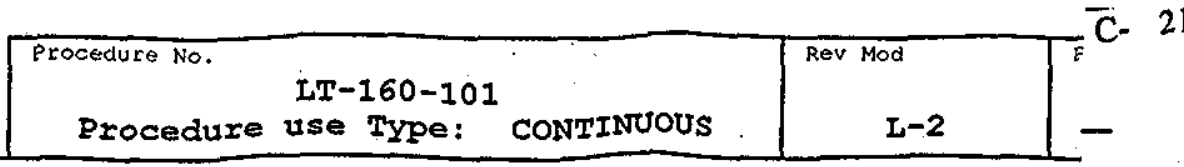


10.3.2 Preparations for Interim Stand-by and Housekeeping.

1. Fit blind sampler (with gasket) onto extractor.

2. Fit bottom flange onto extractor.

3. Open valve $T$ and allow entire system to dry and off-gas in preparation for the next processing session.

4. Ensure new vapor canisters are installed at $H$ ports and at auxiliary port.

5. Ensure following valve configurations: CLOSED: $C M(2$ or 1$), N(1,2,3)$, a port plugged, $S, U$, $V, W(1,2,3), Y\} ;$ OPEN: $\{A, B, C, D, E, F, G$ (to collector), $H(1,2,3), J(1,2,3), K(1,2)$, M(1 or 2), N4, R, $T, Z\}$.

6. Configure vacuum pumps as appropriate.

7. Turn off power to stepper motors.

8. Ensure heater/chiller unit is off.

9. Prepare hot cell area for next processing session and perform housekeeping as appropriate.

10. Ensure hot cell services (water and air) are turned off.

APPENDIX A. Glossary

Auxiliary Manifold A manifold situated in the control cabinet but on the extractor side of the mercury displacement pump where vapor canisters may be staged for vapor capture directly from the extractor. The auxiliary manifold is equipped with its own vacuum and purge gas capabilities.

Bottom $F$ lange The bottom $f$ lange of the extractor where the sample material is released from the extractor after being processed. The bottom flange contains a fitted gasket $(H-2-821610-47)$ and a bearing for the mixing rotor $(H-2-821610-4)$.

Bulk Sample Volume Determination A procedure which employs the principle of the ideal gas law to determine the volume of the sample material that is present in the extractor. When calculating this determination, it is important that correct valve configurations are observed for accurate determinations and that diluent volume must be accounted for.

Bulk Vapor Extraction The first major extraction exercise performed on the extruded sample material. This procedure normally requires thirteen cycles of the mercury pump. Vapor samples collected during this phase may be collected simultaneously, in triplicate.

Collector side Manifold Generally, this involves the tubing and valves of the RGS system which exist on the "discharge" side of the mercury displacement pump. Precisely, the collector side manifold includes the volume of the one-half filled sight glass, and 1) all the volume occupied through the $H$ valves and the collection canisters during the Bulk Vapor Extraction phase and the Equilibrated Vapor Extraction phase, or 2) only the volume of the manifold to the $H$ valves (closed) during the Exsolution (q.v.) phase.

Coupler The interface between the sample and the extractor which consists of a compression clamp and a rubber seal $(H-2-821860-20)$.

D Collection Canister A vapor canister connected to the Auxiliary Manifold.

Exsolution The process by which gas retained in a sample is separated from the bulk of the sample through exhaustive extractions. This action describes the physical separation of gas from the sample by lowering the ambient pressure about the sample below its inherent vapor pressure. The exsolution process describes the extraction of gas as it exists already as a gas or as a condensed or solvated vapor. In contrast, "evolution" of gas from the sample implies that gas is being generated from the bulk sample through chemical activity such as the evolution of hydrogen gas from the chemical reaction of caustic solution on aluminum metal.

Extractor side The section of the RGS system including the extractor, extractor manifold, secondary volume (q.v.), pressure transducer manifold, and all tubing, valves, and filters that exists between the extractor manifold and valves $F / G$ and valve $Z$.

Extractor Manifold The section of tubing including valves $R$, $S$, and $T$ that exists between the extractor and the secondary volume.

Extractor volume The accepted volume of the empty, dry extractor but including the mixer rotor and equal to $1290 \mathrm{cc}$.

Extruder The actuator and ram that hydraulically ejects the sample from the sampler into the extractor. The control unit of the hydraulic ram is located outside the hot cell and consists of a reservoir of hydraulic fluid, a pump, and a system of valves and regulators to control the force and speed of the ram.

$j$ Collection Canister The vapor canisters that are stage at the collector manifold at the $H$ valves. 
1. Ensure rotary vane pump is running.

2. Ensure the following valve configurations: CLOSED: $(B, K 2, M 2, N(1,2,3,4), R, S, U, V$, $W(1,2,3), Y, Z) ; O P E N$ : $\{A, C, E, F, G$ (to collector), $H(1,2,3), J(1,2,3), K 1, M 1, T\}$.

3. Ensure stirrer motor is rotating at $60 \mathrm{rpm}$.

4. Ensure heater/chiller is controlling to $10^{\circ} \mathrm{C}$ and extractor temperature $" 10^{\circ} \mathrm{C}$.

5. Set automatic data acquisition to 10 -second interval data log and record data file name in notebook.

6. Adjust pressure indicator zero offsets as necessary.

7. Record system's temperature and pressure in notebook.

8. Ensure pump pressure is less than 78 millitorr.

9. Close valve $K I$ and $H(1,2,3)$.

10. Open valve $B$.

11. Perform the following sequence eighteen (18) times:

a. Raise mercury reservoir above 0-point.

b. close valve $F$.

c. Open valve $U$ and control the flow of mercury to sight glass with valive $G$ and height of reservoir.

d. Lower mercury reservoir to bottom of travel.

e. Record system's pressure and temperature in notebook.

f. If first or tenth cycle:

(1) Open valves $H(1,2,3)$.

(2) Wait for pressure stabilization.

(3) Close valves $J(1,2,3), H(1,2,3)$ and record canister/sample ID, pressure and temperature in notebook.

(4) Replace vapor canisters at H ports (with J. valves already open).

g. Turn valve $G$ to collector side.

h. Open valves $H(1,2,3)$.

i. Open valve $\mathrm{K} \uparrow$ and wait till pump pressure falls below 78 millitorr.

j. Close valves $H(1,2,3), K 1$, and $U$.

k. Open valve $F$.

1. Check off completed cycle number:

\begin{tabular}{|c|c|c|c|c|c|c|c|c|}
\hline 1 & 2 & 3 & 4 & 5 & 6 & 7 & 8 & 9 \\
\hline 10 & 11 & 12 & 13 & 14 & 15 & 16 & 17 & 18 \\
\hline
\end{tabular}

12. Raise mercury reservoir above 0-point.

13. Close valve $\mathbf{F}$.

14. Open valve $U$ and control the flow of mercury to sight glass with valve $G$ and height of reservoir.

15. Lower mercury reservoir to bottom of travel.

16. Record system's pressure and temperature in notebook.

17. Open valves $\cdot H(1,2,3)$.

\begin{tabular}{|l|c|c|}
\hline Procedure No. & Rev Mod & LT-160-101 \\
Procedure use Type: CONTINUOUS & L-2 & - \\
\hline
\end{tabular}


18. Wait for pressure stabilization.

19. Close valves $J(1,2,3), K(1,2,3)$ and record canister/sample 10, pressure and temperature in notebook.

20. Remove the vapor canisters from the RGS system.

21. Survey each vapor canister by swabbing in and around the connector tube and then surveying the swab for removable radioactive contamination.

22. Replace vapor canisters at $H$ ports (with $J$ valves al ready open).

23. Turn valve $\mathrm{G}$ to collector side.

24. Open valves $H(1,2,3)$.

25. Open valve K1.

26. Close valve $T$.

27. Ensure rotary vane pump is running and valve $M 1$ is open.

28. Ensure valve $K 1$ is open.

29. Stop data acquisition, close file, and copy data file to floppy disk.

30. Turn off heater/chiller unit.

31. Ensure the following valve configurations: CLOSED: $K K 2, M 2, N(1,2,3,4), R, S, T, U, V$, $W(1,2,3), Y, Z\} ; O P E N:\{A, B, C, E, F, G$ (to collector), $H(1,2,3), J(1,2,3), K 1, M 1\}$.

10.2.5 Addition of Dituent and Equilibration Interim

1. Ensure rotary vane pump is running.

2. Ensure stirrer motor is rotation at $60 \mathrm{rpm}$.

3. Ensure the following valve configurations: CLOSED: $\{K 2, M 2, N(1,2,3,4), R, S, T, U, V$, $W(1,2,3), Y, Z)$; OPEN: $\{A, B, C, E, F, G$ (to collector), $H(1,2,3), J(1,2,3), . K 1, M 1\}$.

4. Dispense approximately $100 \mathrm{~mL}$ diluent through valve $W 2$ and then ensure valve w2 is closed.

5. Dispense $300 \mathrm{~mL}$ diluent through valve $W 1$ and the ensure valve $\mathrm{W} 1$ is closed.

6. Record date, time, event, and temperature.

7. Acquire a sample of the diluent and standard solution for chemical analysis (20 $\mathrm{mL}$ each).

8. Allow the contents of the extractor to mix, stir, and equilibrate for the required interim.

10.2.6 Equilibrated Vapor Extraction

1. Ensure rotary vane pump is running.

2. Ensure valve $T$ is closed and valves $K I$ and $M I$ are open.

3. Ensure the following valve configurations: CLOSED: $C K 2, M 2, N(1,2,3,4), R, S, T, U, V$, $W(1,2,3), Y, Z\}$; OPEN: $(A, B, C, E, F, G$ (to collector), $H(1,2,3), J(1,2,3), K 1, M 1\}$.

4. Ensure stirrer motor is rotating at $60 \mathrm{rpm}$.

5. Ensure heater/chiller is on and controlling to $10^{\circ} \mathrm{C}$ and extractor temperature $\sim 10{ }^{\circ} \mathrm{C}$.

6. Set automatic data acquisition to 10 -second interval data $\log$ and record data file name in notebook.

7. Ensure system pressure is less than $0.01 \mathrm{kPa}$.

8. Adjust pressure indicator zero offsets as necessary.

9. Close valive $\mathrm{K} 1$.

10. Open valive $T$ and wait until system's temperature and pressure stabilizes.

11. Record date, time, event, temperature, and pressure in notebook. 
12. Close valve $F$ and ensure valve $G$ is turned to the collector side.

13. Perform the following steps nineteen (19) times:

a. Raise mercury reservoir above 0-point.

b. Open valve $U$ and control the flow of mercury to sight glass with valve $G$ and height of reservoir.

c. Lower mercury reservoir to bottom of travel.

d. Record temperature and pressure in notebook.

e. Turn valve $G$ to extractor side and wait until mercury completely evacuates displacement bulb.

f. Close valve U.

g. Turn valve g to collector side.

h. Check off completed cycle number:

\begin{tabular}{|c|c|c|c|c|c|c|c|c|c|}
\hline 1 & 2 & 3 & 4 & 5 & 6 & 7 & 8 & 9 & 10 \\
\hline 11 & 12 & 13 & 14 & 15 & 16 & 17 & 18 & 19 & \\
\hline
\end{tabular}

14. Raise mercury reservoir above 0-point.

15. Open valve $U$ and control the flow of mercury to sight glass with valve $G$ and height of reservoir.

16. Lower mercury reservoir to bottom of travel.

17. Record temperature and pressure in notebook.

18. Close valves $\mathrm{J}(1,2,3)$ and $H(1,2,3)$.

19. Record sample, canister 10, temperature, and pressure in notebook.

20. Stop data acquisition, close file, and copy data file to floppy disk.

21. Remove the vapor canisters from the RGS system.

22. Survey each vapor canister by swabbing in and around the connector tube and then surveying the swab for removable radioactive contamination.

23. Place three new canisters (with $\mathrm{J}$ valves open) at $\mathrm{H}$ ports and Ensure plug at auxiliary port.

24. Open valves $H(1,2,3)$ and turn valve $G$ to collector side.

25. Open valve $K 1$ and Ensure rotary vane pump is running valve $M 1$ is open.

26. Ensure the following valve configurations: CLOSED: $(K 2, M 2, N(1,2,3,4), R, S, T, U, V$, $W(1,2,3), Y, Z\}$; OPEN: $(A, B, C, E, F, G$ (to collector), $H(1,2,3), J(1,2,3), K 1, M 1)$.

27. Turn heater/chiller unit off.

10.2.7 Bulk Sample Volume Determination (BSVD)

1. Ensure rotary vane pump is running.

2. Ensure the following valve configurations: CLOSED: $(K 2, M 2, N(1,2,3,4), R, S, T, U, V$, $W(1,2,3), Y, Z\}$; OPEN: $\{A, B, C, E, F, G$ (to collector), $H(1,2,3), J(1,2,3), K 1, M 1\}$.

3. Ensure stirrer motor is rotating at $60 \mathrm{rpm}$.

4. Ensure extractor temperature is roughly equal to collector side temperature.

5. Set automatic data acquisition to 10-second interval data log and record data file name in notebook.

6. 'close valve F.

7. Open valves $N 3, N 4, R, T$; and $Z$.

8. Allow a short pause for pressure to equilibrate and then close valve $z$. 
9. Perform the following steps three (3) times:

a. Evacuate the system to about $4 \mathrm{kPa}$ using vatve F.

b. Wait for the system to equilibrate and then record extractor pressure (as variable P1) from 1000-torr pressure transducer display.

c. Close valve $r$.

d. Open valve $z$.

e. Wait for the system to equilibrate and then record extractor pressure (as variable P2) from 1000-torr pressure transducer display.

f. Close valve $Z$ and open valve $T$.

g. Wait for the system to equilibrate and then record extractor pressure (as variable P3) from 1000-torr pressure transducer display.

10. Determine "Bulk Sample Volume Determination" per equations $2 a$ and $2 b$ and record in notebook.

11. Ensure heater/chiller unit is off.

12. Ensure rotary vane pump is running, valves $K 1$ and $M 1$ are open, and valve $F$ is closed.

13. Open valves N3, N4, and Z.

14. Pause briefly to allow pressure to equilibrate and then close valve .T.

15. close valve $\mathrm{N3}$.

16. Open valve F.

17. Close valve $C$.

18. Exchange plug at Port $D$ with opened canister. .

19. Open valves $\mathrm{C}$ and $\mathrm{K} 2$.

10.3 Sampler Disassembly and Clean-Up

10.3.1 Disassembly and Sample Remova!

1. Ensure valve $T$ is closed.

2. Place large pan under extractor.

3. Remove sampler from extractor and prepare it for load-out.

4. Drop bottom flange from extractor.

5. Collect sample and stow as appropriate.

6. Wash entire extractor interior and parts with water and dry with air. 
APPENDIX A. Glossary (Cont inued)

Mercury Positive Displacement Pump A simple positive displacement pump that uses mercury metal to force the suction and flow of gas from the extractor side to the collector side of the RGS system. The direction of flow and suction is provided by a three-way valve, valve G. The flow of mercury is motivated by the position of a reservoir which can be lifted or lowered about 100 centimeters from the 0 -point (q.v.). The reservoir is vented to atmosphere to provide the necessary pressure to allow the mercury to be drawn up into the displacement chamber and sight glass.

Retained Gas Gas that is generated as a result of chemical or radiolytic decomposition of waste tank material. The gas is called "retained" because it contributes to the bulk volume of tank waste materiat as bubbles, foam, or even dissolved within the slurry or interstitial liquid.

sight Glass The very top of the mercury displacement pump where the mercury can be seen when it reaches that level.

Secondary Volume An empty container whose volume has been carefully measured to be $321.46 \mathrm{cc}$ and is used to verify the volume of other sections of the RGS system using the principle of the ideal gas law.

Stirrer Motor The motor affixed to the extractor which turns the mixer blade inside the extractor. Between the motor and the mixer blade is a reduction gear box that slows the mixer speed to 1/20th of. the motor speed.

0-Point The point of elevation of the index of the mercury reservoir that would cause the level of mercury in the displacement pump to rise exactly to the middle of the sight glass in which $0 \mathrm{kPa} p r e s s u r e$ (abs.) exists in the collector side manifold.

3/4-Point The level of the column of mercury that would allow the displacement chamber to be $75 \%$ full.

\section{All prendix C. Endnotes (continued)} All pressure indications in this procedure are expressed in terms of ABSOLUTE pressure.

2 An in-line depth filter has been installed in the transfer tube, just outside the hot cell wall to prevent the transfer of radioactive contamination out of the hot cell environment.

3 Usualty $300 \mathrm{~mL}$ diluent is added.

4 This value is obtained from the Bulk sample volume Determination q.v.

s Vapor canister volumes range from 50 to $150 \mathrm{cc}$, depending upon the canister used.

6 The extractor is cooled to about $10^{\circ} \mathrm{C}$ to prevent excessive amounts of water vapor from evaporating from the sample material and fouling the in-line depth filter or condensing onto the tubing, displacement chamber, or collector manifold.

q.v. means "see also"

B There are three canisters so that duplicate (or triplicate) samples can be acquired simultaneously. They are transported and analyzed as separate vapor samples for independent analyses.

9 : Laboratory Controlled Notebook: WHC-N-164, pp. 64-78.

The apparent quantity of vapor contains more water vapor and ammonia than what would be observed if particular care is afforded in preventing the accumulation of these vapors.

Release disk and retainer ring components do not have to be removed from the sampler.

Vapor canisters installed at the $H$ ports are designated as having "J" valves. Vapor canisters installed at the auxiliary port are designated as having "D" valves. Vapor canisters installed at the $Q$ port are designated as having "up" valves.

The turbo-molecular vacuum pump should never be used to draw a vacuum on systems whose pressure is greater than $1 \mathrm{kPa}$. Rather, the rotary vane pump should be employed during the initial "roughing" of the vacuum. The turbo-molecular pump should only be used after the rotary vane pump has al ready evacuated the system to less than $1 \mathrm{kPa}$. Also, both pumps should not be allowed to pump simultaneously from a common manifold so that oily vapors are not continually vented from the rotary. vane pump to the turbo-molecular pump.

It is possible for mercury to overflow the sight glass and collect in the collector side manifold. This event would have a deleterious affect on the performance of the RGS system (for a number of reasons); therefore, this activity must be performed delicately and carefulty.

$\mid$\begin{tabular}{l|l} 
Rev Mod & P \\
$\mathrm{I}-2$ & -
\end{tabular}

